


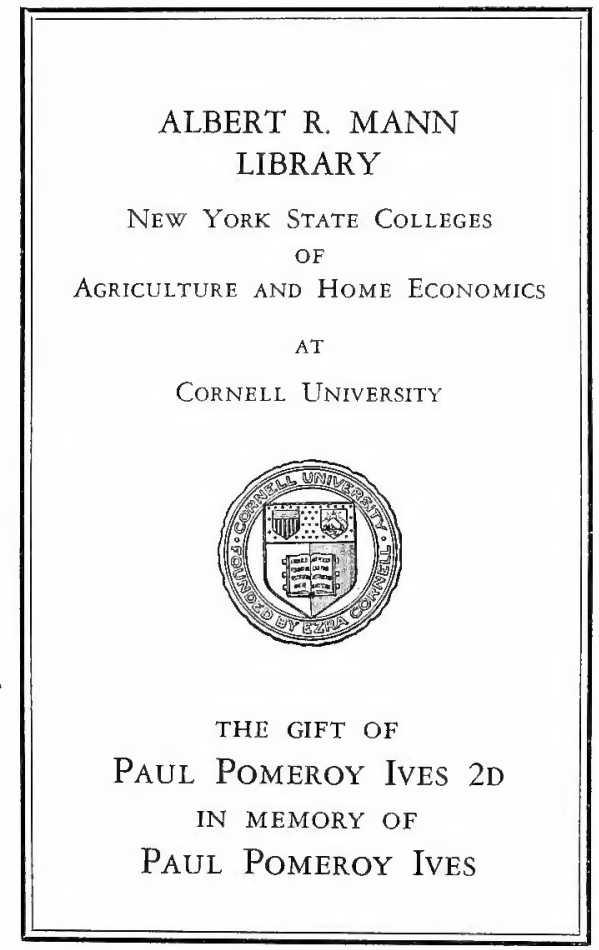




\section{Cornell University Library}

SF 465.484

Pigeons and all about them.

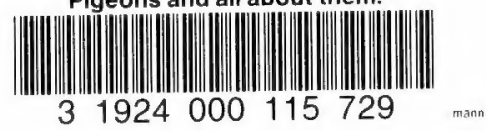




\section{Cornell University Library}

The original of this book is in the Cornell University Library.

There are no known copyright restrictions in the United States on the use of the text.

http://www.archive.org/details/cu31924000115729 




\section{PIGEONS}

AND ALL ABOUT THEM. 


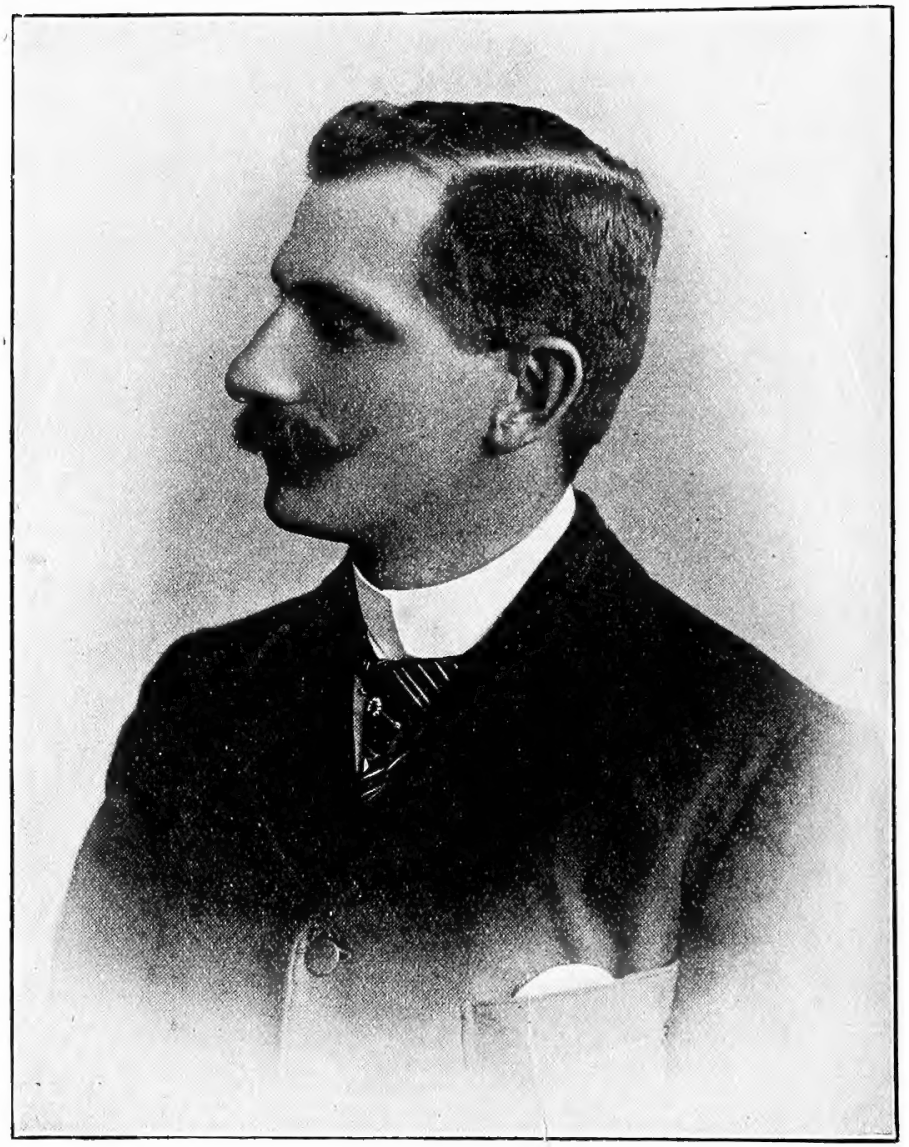

Mr. C. A, House. 


\title{
PIGEONS AND ALL ABOUT THEM.
}

\author{
$\mathrm{BY}$ \\ C. A. HOUSE.
}

Author of "The Fantail Pigeon," "Long-faced Tumblers, and All About Them," "Bantams and How to Keep Them," "Rabbits, and All About Them," "Rabbits for Food," "CatB, Show, and

Pet," "Cavies, their Varieties and Management," "House's Canary Manual," "British Birds and Hybrids,"

"Canary and Hybrid Culture," etc.

THIRD EDITION. REVISED.

IDLE, BRADFORD :

Printed and Published at the office of "Pigeons and Pigeon World." 



\section{PREFACE.}

So far as Pigeon books are concerned, the majority of existing works deal very largely with the technical and more advanced, and not enough with the elementary and practical side of Pigeon-keeping. It has been my desire in writing "Pigeons, and all about them," to make it easily understood, and to this end $I$ have avoided, as much as possible, the idea that my readers have got beyond the elementary stagc. I have also endeavoured to eschew the use of highly technical language, and to write in a plain, practical manner, so that the young fancier may readily understand my meaning, and the earnest sceker after Pigeon knowledge find that which he seeketh.

Another strong reason why I have undertaken the compilation of "Pigeons, and all about them," is because many of my friends, who for the past twentyfive years have followed my writings in "The Fanciers" Gazette," "Pigeons and Poultry," and "Pigeons," have expressed a desire to possess the same in a complete and more permanent form.

A third reason, and by no means the least, is that my old friend and colleague, Mr. J. E. Watmough, the Editor of "Pigeons," whom I have known for a big slice of my life, and with whom, for over thirty years, I have worked in closest friendship and most hearty accord, asked me to undertake this work.

So much as to the reason why "Pigeons, and all about them," has been prepared. I send it forth conscious that it is far from perfect, but I ask for it that kindly indulgence which the fanciers of the 
viii Pigeons and Ali About Thend.

United Kingdom have ever given to my work; and not only from fanciers at home do I ask this, but also from those of that Greater Britain beyond the seas, and of America, many of whom have, from time to time, written to me upon matters concerning the Fancy, and who have shown much aypreciation of my past work.

\section{A. HOTSE.}

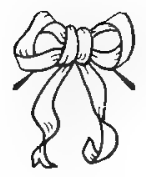




\section{CONTENTS.}

\begin{tabular}{|c|c|c|}
\hline CHAP'IER & I.-Housing & \\
\hline Chapter & II.-SELECTION OF STOCK & \\
\hline CHAPTER & III-CGENERAI MANAGEMENT & \\
\hline CHAPTER & IV.-BREEDING & \\
\hline CHAPTER & V.-EMIBRYOLOGY & \\
\hline CHAPTER & VI.-CONCERniNG Pigeon's MiI & \\
\hline Chapter & VII.-The Moulting Season & \\
\hline HAPTER & VIII.-Successful Ëxhibiting & \\
\hline ChaPter & IX.-The Washing of Pigeon & \\
\hline CHAPTER & X.-The Breieds OF PIgeONS & \\
\hline HAPTER & XI.-DISEASES & \\
\hline
\end{tabular}





\section{LIST OF ILLUSTRATIONS.}

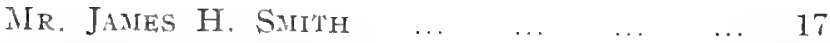

$\begin{array}{lllllll}\text { MIR. W. WATHOUGH } & \ldots & \ldots & \ldots & \ldots & 27\end{array}$

1917 SIIVER FNGI,ISH OWL HEN $\ldots$

White Fantall COCK, "Dandy Prince," .. 41

DR. W. E. BARKER, M.B., СH.B. ... ... . 1

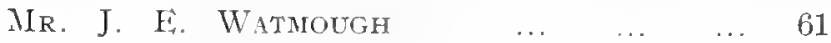

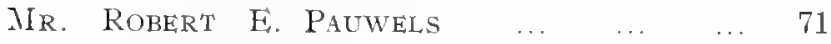

MR. R. H. BELLAMY $\quad \ldots \quad$.

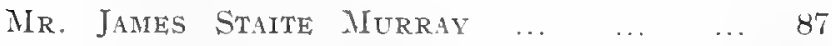

CAPT. ST. JOHN HORnBy $\ldots$...

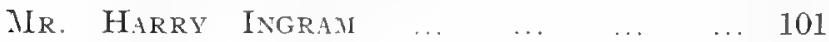

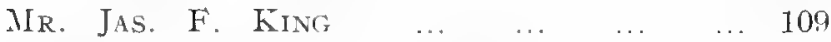

RED LACE FANTAIR, "AUTUMN LEAF", ... 15

1914 BLUE ENGLISH OWL COCK, "LORD EITCHENER "

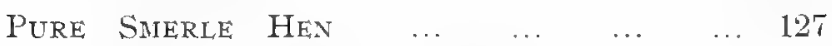

Mr. G. A. PEILING HANDIING YELLOW $\begin{array}{lllllll}\text { CHEqUFR COCK } & \ldots & \ldots & \ldots & \ldots & 135\end{array}$

ADULT YelLOW DragoON COCK $\ldots . \quad \ldots \quad 143$

OUR NEWEST BREED-" MARTIAN," A TYPICAI. YEI,LOW MARTHAM HEN

1919 Black Chequer Antwerp Hen. .. 157 1919 STRAWBERRI MEALY SHOW HONER COCK 103 THE HOME OF THE NETARK RED SELF $\begin{array}{lllllll}\text { Tundilers } & \ldots & \ldots & \ldots & \ldots & \ldots & 171\end{array}$ 
xii Prgeons and ALI About Thenr.

\section{White Piglry Pouter Hen, "Lady} $\begin{array}{lllllll}\text { BAYARDO } " & \ldots & \ldots & \ldots & \ldots & \ldots & 177\end{array}$ Red Norwteh Cropper Hen $\ldots$.. Blue L.F. SADdle BaLd TUMbler, "Biliy" 187 Long-Faced Black SelfF Tumbler Hen,

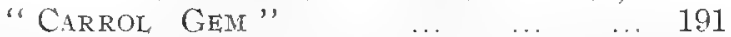
A Fanous Long-Faced Black Beard Tumbler 199 Red Self L.F. Tunibler Hen, "Idde Jean" 20 T Two of Mir. R. A. Briggs' Chamipion African $\begin{array}{lllllll}\text { OWLS } & \ldots & \ldots & \ldots & \ldots & \ldots & 217\end{array}$ $\begin{array}{llllllll}\text { LILLE CROPPER COCK } & \ldots & \ldots & \ldots & \ldots & 223\end{array}$

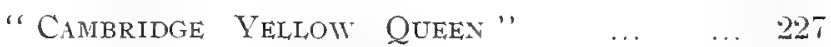

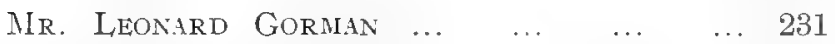
Two Yeiliow-Pied Pigmy Pouter Winners ... 235 $\begin{array}{llllllll}1916 & \text { Red TURBIt HeN } & \text {.. } & \ldots & \ldots & \ldots & \ldots & 239\end{array}$ $\begin{array}{lllllll}1908 & \text { BLACK TURBit HeN } & \text { Te } & \ldots & \ldots & \ldots & 243\end{array}$

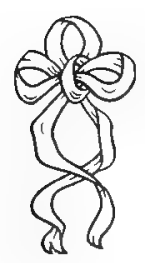




\section{INTRODUCTION.}

In the past writers of Pigeon books have generally made their first chapter historical. It is possible to play too much upon one string, and I intend to discard this historical one for the simple reason that nothing of practical value can be gained by my readers from an enumeration of Pigeon lore from the days of Noah and the Dove until the twentieth century. In the course of one year something like one million Pigeons are bred in the United Kingdom alone. These figures seem stupendous, yet when one comes to analyse them they are found to be well within the mark. In the first place, there are abottt 100,000 Pigeon keepers in the kingdom, many of whom breed anything from 50 to 200 birds in a season, thus it will readily be seen that in putting one million as the number of Pigeons bred in one season I am well within the mark, as it is only an average of ten to each breeder.

\section{PIGEON BREEDING OF TO-DAY.}

Pigeon keeping and breeding to-day stands on a far more exalted plane that it did years ago, when everything connected with Pigeons was considered to be plebian and low. King Edward the Peacemaker, and King George $V$. both have been known breeders, keepers, and lovers of Pigeons. Many men of high degree are also interested in Pigeon culture, and thus the reproach has been wiped out.

Again, the value of high-class Fancy Pigeons has done not a little to bring into the ranks of columbophilists a better class of man, and to-day we find in all branches men of culture and intellect engaged in the peaceful, genial, and profitable hobby of Pigeon breeding. To the uninitiated the high prices which firstclass Fancy Pigeons realise seem quite fabulous, and to "the man in the street" the idea of $£ 100$ for a Pigeon 


\section{xiv, Pighons and Ali, About Thent.}

seems madness. Yet this price has been paid 11pon many occasions, and for different breeds, whilst $x^{2} 0$, $£ 40, £ 30$, and $\$ 20$, are common everyday prices; and once the high figure of $₫ 200$ was paid for a Pigeonan English Owl.

\section{PERFECTION THE GOAL.}

Although so many thousands of breeders are engaged in the pursuit of breeding high-class Pigeons, the perfect bird has yet to be produced. This is where the great charm of the Fancy lies. Perfection is the goal, but as we near the goal our ideal becomes higher, we see points which need refining which we had previously overlooked, and thus the object of our ambition is kept from our reach. Well it is that it is so, because it makes the fight for supremacy keener, and tends to more healthy rivalry. Another great charm about the Pigeon $\vec{F} a n c y$ is the manner in which its favours are distributed. The successful man is not alway's he who by reason of his wealth is able to build palatial aviaries, and fill then with the bluest of blue-blooded stock. These men find that whilst their wealth will do much for them, it will not unaided secure them the highest prizes of the Pigeon Fancy. Well it is that it is so, and that the earnest toiler, the man of small means, yet rich in practical knowledge and experience, stands as good a chance of breeding the champion Pigeon of the year as his richer brother.

This being so, there is a chance for the youngest, as well as the poorest, fancier, if he will possess his soul in patience, to reach the height of his ambition, and breed the champion of the year.

\section{WHY MEN BECOME PIGEON BREEDERS.}

For diverse reasons do men enter the ranks of columbophilists. Some desire to add to their incomes, some seck pleasure and relaxation from the cares of business, and some to while away the time and give them zest and interest in life. All seek and find what they want. There are men known to me to-day who when they first commenced Pigeon breeding did so with the object of securing that relaxation of which I have spoken, yet so carnestly and practically did they" pur- 
suc it that they quickly found that it considerably augmented their income year by ycar, and now these self-same men have abandoned their trades and professions and live entirely out of the income derived from their Pigeons.

\section{ALL STAR'T LEVEL.}

Whatever position a Pigeon lover may ultimately attain in the Fancy he has to start like all his fellow's at the bottom rung of the ladder. None of us commence the breeding of Pigeons with a ready-made storehouse of kllowledge. True, some have a greater aptitude for dealing with live stock than others, and more quickly grasj the lessons that must be learned, yet they have to go through the probationary stage just the same as their more slow-witted brethren. From this it will be gathered that health, relaxation, recreation, pleasure, and profit may all be found in the Pigeon Fancy.

\section{TO AID THE NOVICE.}

I have said that my chicf object in writing this work is to aid the beginner to so advance that he may readily grasp and overcome the mysteries, the difficulties, and the intricacies of the art of becoming a successful brecder and exhibitor of high-class Pigeons. "Pigeons, and all about them," is not an advanced treatise. It does not profess to cater for the experienced breeder, but rather for the novice, who, devoid of the knowledge derived from actual experience, needs some guidance, some assistance in dealing with the mazy problems that arise and confront him in his carly eftorts.

In a work of this character, in which space is necessarily limited, not much can be said upon the different breeds MIy notes upon them will be brief, but I shall devote all the space that is needful to the more practical side of Pigeon keeping, and to give such instruction in housing, feeding, and rearing as wul enable my readers to reach to the heights and delights of exhibiting, in which I shall also strive to direct their efforts to a pleasurable and successful issue. 



\section{CHAPTER I.}

\section{HOUSING.}

Of Pigeon houses there are lesigns innumerable, but many of them, such as the locker against the wall, the cote on the top of a pole, and the artistic threedecker arrangements for lawns, are not suitable for the breeder who wishes to breed bircls for exhibition purposes. Such houses as these cannot be properly cleansed, and are far more adapted to the process of breecling vermin than to the breeding of Pigeons. Such habitations are most insanitary, and totally unfitted for the breeding of high-class stock. In a Pigeon house, there are three essentials needed. It must be perfectly damp and clraught proof, and it must be well ventilated. Pigcons are hot-blooded creatures, and can withstand a tolerable amount of cold providing the atmosphere in which they live is dry. Damp and draughts they cannot stand, and the strongest quickly succumb to the influences of either. Therefore, secure dwellings which are dry, well ventilated, yet not draughty.

\section{NOT CHOICE, BUT FORCE.}

Pigeons, like their owners, have to dwell in diverse places, and the lover of Pigeons forced to live in a town cannot possibly give his birds the accommodation that one living in the country can. Yet under the most unlikely and unfavourable conditions much may be done by the zealous fancier possessed of a fervent love for his hirds, and an unbounding zeal for their comfort Now-a-days few town dwellers are allowed to keep birds in the attic; the sanitary authorities will not allow it. Yet on the Continent there are thousands upon thousands of such lofts; in fact, ninetynine out of every hundred lofts I have seen in Belgium, Holland, Sweden, Denmark, Germany, and France, are situated in the attic at the top of the house. 


\section{A USEFUL TOWN LOFT.}

If the town-rlweller can commenrl a loft orer a shed or stable, sucli can rapidly be converted into a good dwclling place for Pigeons. One-half might be wired off, and used as the breeding place, and the remainder used for the young birds. If large enough, it may be again divided, but in such a lnft the firds should be

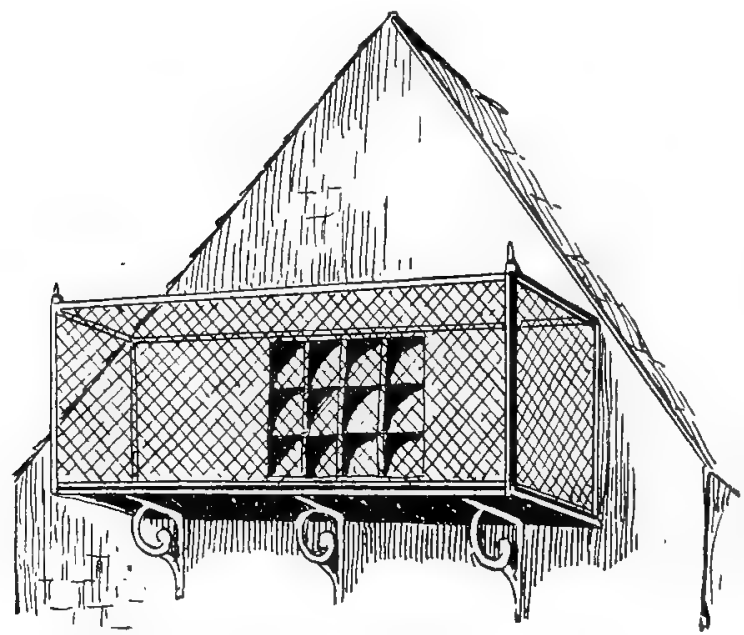

Flight attached to Window of a Stable Loft Aviary.

given more space for exercise than in an out-cloor clwelling. A loft so situated should contain fewer birds than one of the same size built in a field or garden, because the winds of heaven will not have stich free access to it, and the birds will not obtain so n11uch fresh air as their more favoured brethren.

Closely associated with the character of the dwelling place is the question of breed to he kent. Stables, sheds, onthouses, and lofts in the confined yards of a town are only suitable for such breeds as Lung-faced Tumblers, short-faced Tumblers, colourel Fantails, Archangels, and other small breets. They are most unsuitable for sutch breeds as Drapoons, Antwerls, and 
others which need plenty of fresh air and exposure to keep their ceres and wattles in good order.

\section{AN ADDED CONVENIENCE.}

Such lofts may be made of considerably more use if it is possible to erect an outside flight (such as illustrated) in front of the window. This would allow the birds coming out and sccuring not only fresh air, but a sun-bath occasionally; and one has only to watch Pigeons for a very little while to become convinced of the fact that they do enjoy basking in the sun. Pigeons, like cats, will lie for hours in the blazing sum of the hottest day in July or Alugust. 'This being so, it will readily be seen that any house provided for their accommodation will yield better rusults if it gives them the opportunity of taking a sun bath whenever they feel inclined. In fitting up such an outsicle flight the boards forming the floor should have a space, say, of half-an-inch left between each board to allow rain and other moisture to drain away quickly.

If this is not done the floor will be continually dam1, and this is not conducive to the health of the birds.

\section{CLEARING THE GROUND.}

A loft or shed of the character described should be thoroughly gutted of all impedimenta cre it is made into a Pigeon loft. You want nothing but bare walls, a floor, roof, door, and windows when you commence the process of conversion. Having cleared out everything, set to and limewash the inside of the roof and walls, having first of all swept and scraped away all dirt and filth should any exist. After clearing and cleansing it, fit up your perches. For the Tumblers and other small breeds the best perches are those in the form of a bracket projecting from the wall. Fantails do better without perches, as they soon ruin their plumage if given them. During the breeding season they may be given a long broad board to fly to, but during the moulting and sliow seasons they are best kept on the floor, and not given the opportunity of perching. If it is at all possible when fitting tp a loft, seek the 


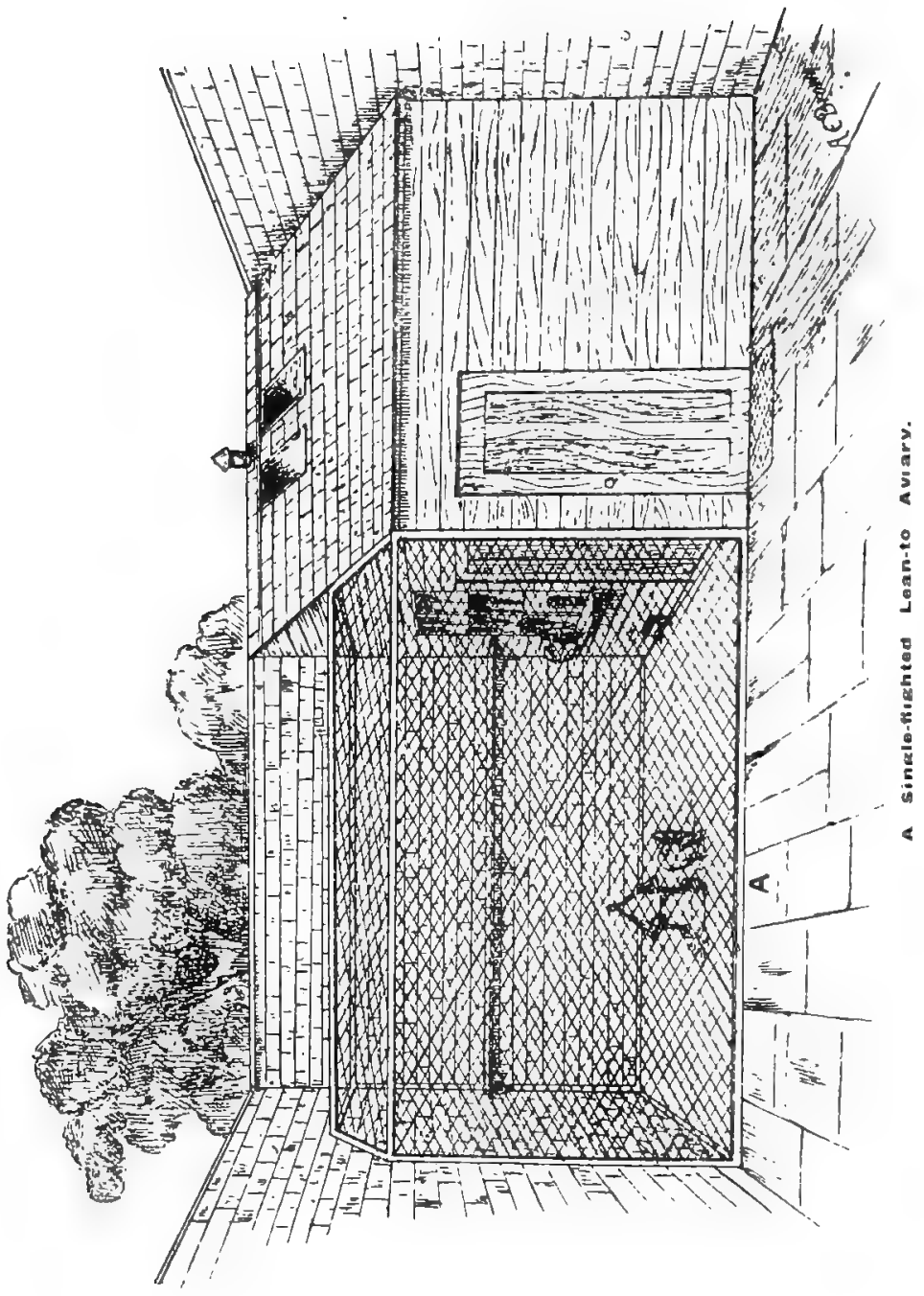


advice and assistance of some old fancier, it will save not only money, but much worry and vexation.

\section{DWELIERS IN SUBURBIA.}

I now pass on to the fancier who is privileged to live in the suburbs of one of our large towns or cities, or the country, and who has command of a walled-in

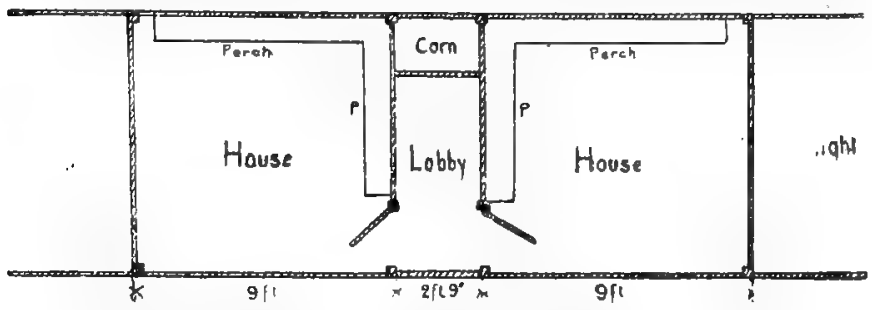

Ground Plan of Double-flighted Lean-to Aviary.

garden. A garden wall is most usetul in such cases. It allows of a Pigeon house being built with economy of space and capital. I have seen hundreds of most admirable little lean-to buildings erected in the gardens attached to suburban dwellings. Such a wall provides a good back to the house and flight, and all

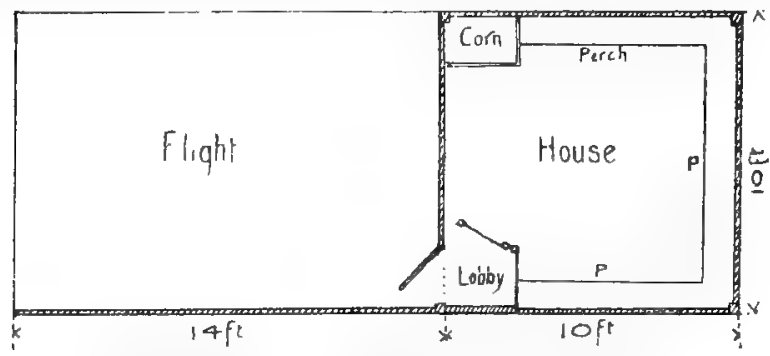

Ground Plan of Single Lean-to Aviary.

that is needed is roof, ends, and front. First of all a stout framework of timber should be set up, the posts for supporting which should be 4 in. by 3 in., and the remainder $2 \mathrm{in}$. by $1^{\mathrm{r}}$ in. The roof should be 3,4 in. 
or lin. boarcls, tongued and grooved, and then covered either with asphaltic felt or corrugated iron. If the latter is nsed it is not advisable to fix it close to the wooden root, but to raise it about an inch so as to allow of a current of air sweeping underneath it.

This will keep the loft cool in summer and warm in winter. The walls should be of the same thickness. In fixing ul) such an aviary, it is well to have two houses, one at each end, and the flight divicled, in the middle; such an arrangement means saving of cost and space. The length and widtl of such an erection must be governed by the space at command.

\section{COTERED FLIGHTS BEST.}

I recommend such flights to be covered the same as the hotise. There are several reasons for this, but the chief one is that cats, which are always prowling about, cannot get through a wooden or corrugated iron roof, whereas they will get through a wired top. Again, in such a situation, dirt, smuts, and blacks abound, and even if one keeps self-coloured birds, such are best kept away. A third reason is that the floor is kept in better condition. The houses proper, or sleeping places, should be built of timber of same thickness as the roof, and may be covered with asphaltic felt, the walls being tarred, or llainted, as the fancy of the owner may direct. If appearances are to be considered, then dark green paint is the thing, with the windows and doors picked out or relieved with white. The floor should also be built of the same thickness of timher. I refer to the floor of the house proper.

\section{THE BOTTOM OF THE FLIGHT.}

The floor of the flight may be covered with sand, or it may be given a layer of concrete and cement. A fair sized window should be affixed to the house, and a like remark applies to the door; but the door should open into the flight, and not direct into the garden, the reason for this being that a bird may, if startled make a dash over one's head, and be out and array hefore there is the slightest chance of stopping it. 


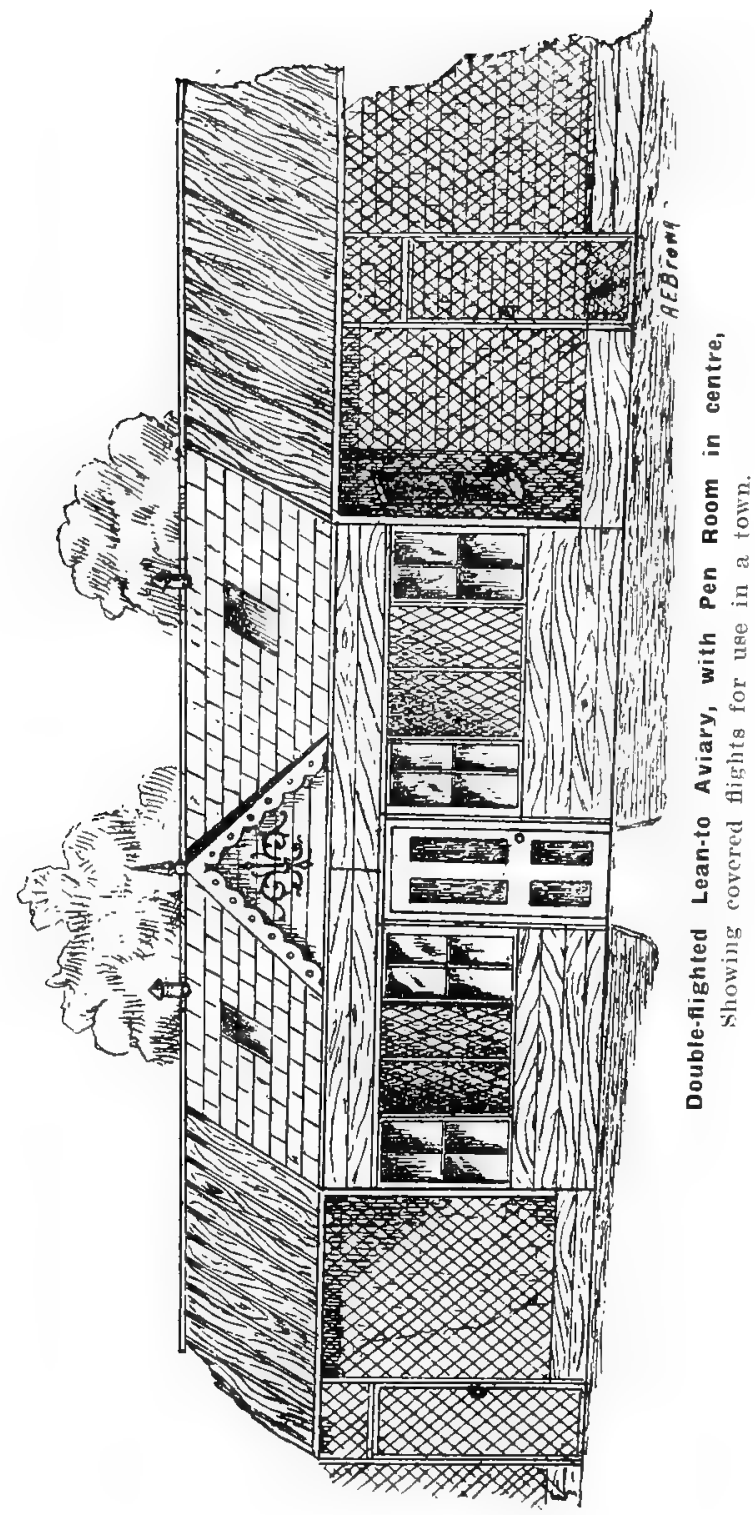


And it is not a very pleasing experience to sec your winner of first and challenge cup at the Club Show careering in the air. If the pocket will allow, the house will be more confortable and nore substantial if it is inner boarded or lined, and the space between the hoards filled with sawdust.

Thare the framework of the roof joins the wall a course of cement should be laik, so as to irevent the ran from beating

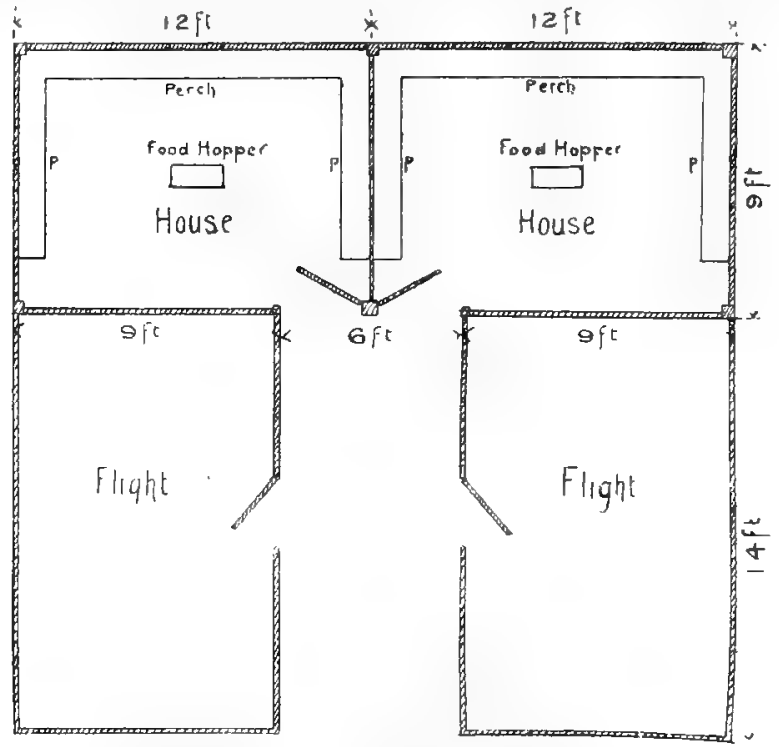

Ground Plan of Double-fronted Aviary.

down the side of the wall. A gutter should be run round the eaves and connected by a pipe with the drain, or else a grood big tub. A rain tub is a useful article for a Pigeon fancier. Rain water is handy for bathing purposes. The front of the flights should be composed of strong ${ }_{4}$ in. nesh wire-netting, and the doorway sliould be not less than $2 \mathrm{ft}$. 6in. in width. Ventilation may be arranged by having what are known as stahle ventilators. That is, a sliding board 
fitted to slide to and fro over a space covered with perforated zinc, close to the roof at either end of the house. The perches in the flight may be fixed to the wall, and the same in the house itself. I am no believer in fixed nesting places, and much prefer to use portable boxes; cube sugar boxes make very useful nest boxes, and they can be destroyed at the end of each season.

\section{HOW MANY DWELLERS?}

The dimensions of such a dwelling must be governed by the space at command. I may, however, give some iclea of the relation of space and the needs of the birds. A lean-to, such as I have described, would, if covering say six feet by 50 , provide accommodation for eight pairs of Tumblers, or other small breeds, or six of Homers, Dragoons, or other large breeds. This would give a house at either end $6 \mathrm{ft}$. by 8 , and two flights $6 \mathrm{ft}$. by 17 . Some would say more should be given. I agree it would be better, but still suburban accommodation has to be considered. One of the two houses would serve as a breeding house, and the other as a nursery for the young birds during the breeding season. Then in the fall when the birds are divided one house will accommodate the cocks and the other the hens.

\section{WHERE SPACE IS NOT VALUABLE.}

In the country where space is not so valuable I prefer a span roofed house, which may be built of wood, in the same manner as that described for the suburban lean-to, or of brick. If one can afford it, and is an owner and not a tenant, I should advise brick buildings in preference to any other. To build a good sized Pigeon house with slate roof is a costly affair, and not one to be taken in hand by the new beginner even if he has the necessary capital. Far better to bicle a wee, try your luck in some more unpretentious erection ere launching out into the spending of a lot of good money. Years ago when I was myself turning out winners with a fair amount of regularity, $m y$ Pigeon houses were wooden erections, six feet six inches at the eaves, rising to ten feet in the centre 


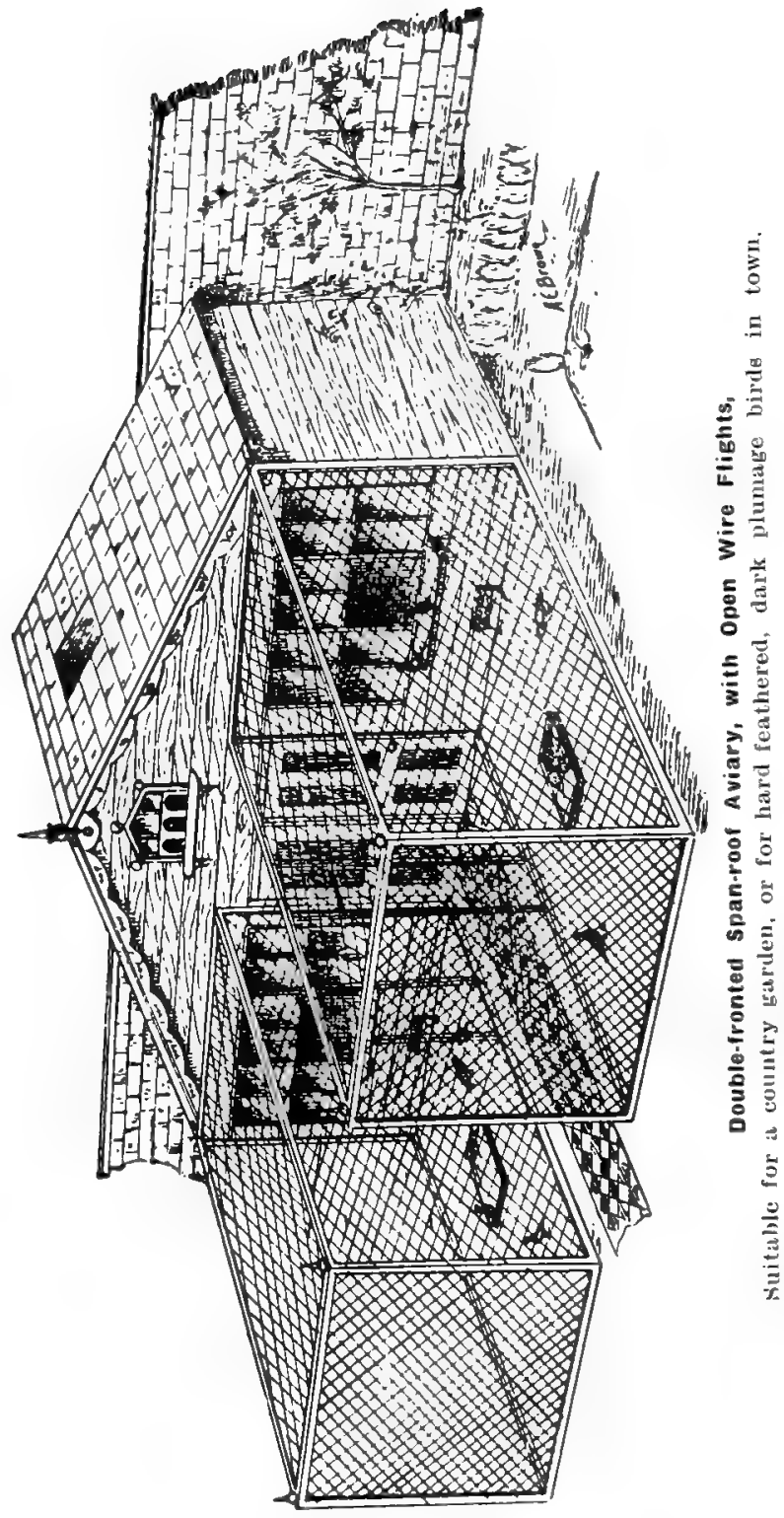


of the roof, which was a span. The ground space ras ten feet by ten, and the houses each had a flight eighteen by ten. They were very strongly built, the framework being 4in. by 3in., and the roof, sides, floors all of $1 \mathrm{in}$. boards, tongued and grooved, the roof being covered with felt. The ends and sides were painted. The birds had egress from the house into the flight through a large sliding window, 3ft. ky $6 \mathrm{ft}$. The flights also were span-roofed, the covering being corrugated iron. In each of these houses I used to breed ten pairs of birds, the young being removed to the nursery when a month old.

\section{A MAGNIFICENT RANGE.}

One of the most practical ranges of Pigeon houses known to me is that of my friend, Mr. Richard Woods, of Mansfield, the famous Dragoon King. This is built of brick, each house having a floor space of $9 \mathrm{ft}$. by $9 \mathrm{ft}$, and a flight $9 \mathrm{ft}$. by $14 \mathrm{ft}$. With this I give a bird's eye view of a section of the range, and a ground plan of the whole. To build such a range of houses is a costly proceeding. The walls are double all round, and are what are known in the building trade as cavity walls - that is, having a space between each. This ensures dryness, and is an aid to efficient ventilation, as ventilating bricks may be used in the top courses. The fronts have substantial door and window frames and sills, and are fitted with the sliding windows of which $I$ spoke in connection with my own lofts. The doors are of one inch thickness, the roof is a lean-to, and this is netted over so as to allow the birds access for their sun bath, of which I spoke earlier on. The ground plan shows a gangway between the two ranges of houses, and this provides a good vantage ground for the owner to watch and study his birds.

\section{COVERED FLIGHTS.}

This stamp of house, whilst most admirable for Dragoons, Homers, Owls, Turbits, Carriers, Antwerps, and other strong clean-legged birds, would not do at all for Pouters, Pigmies, Trumpeters, Fantails, Jacobins, or any of the breeds of delicate colour, stich 


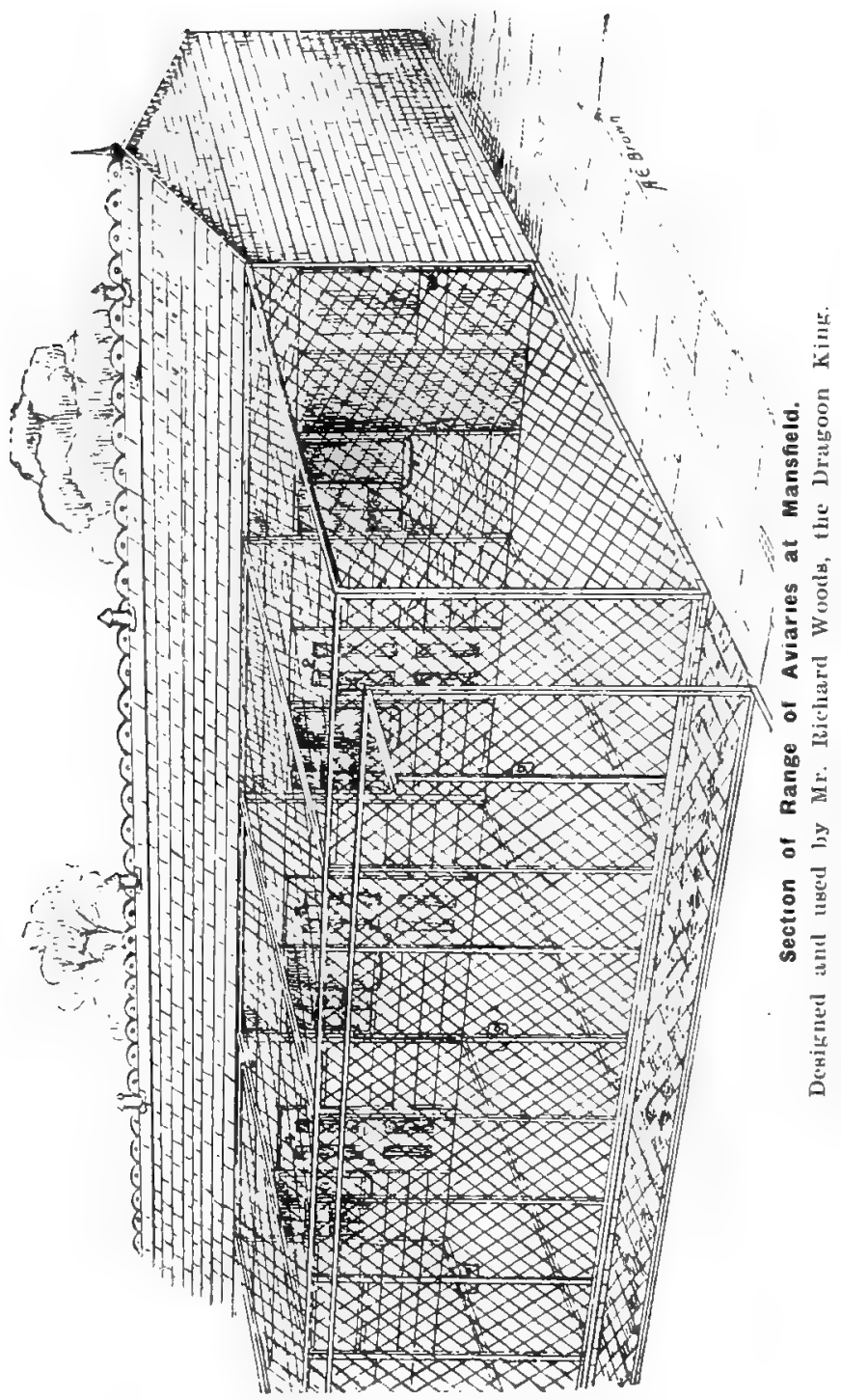


as red, yellow, or almond. For such birds a large house with covered flights is a necessity-for the long feathered birds because of the necd for keeping the feather in good order, and for the delicate coloured bircls to preserve the plumage from the ravages of the sun. Such a house may be built in three divisions. The centre may be the pen and store-room, flanked on either side by a house from which extends the flight. The bottom portion of all flight's should be wood. By this I mean that $2 \mathrm{ft}$. $6 \mathrm{in}$. or $3 \mathrm{ft}$. from the ground should be boarded up. This will keep the birds from being frightened by cats or dogs which may be prowling about, also prevent the rain from driving in on the floor of the flight.

\section{ANO'THER USEFUL LOF'T'.}

For the benefit of those who prefer a lean-to I describe another such house. Built against a garden wall, it should be about eight or nine feet at the back, sloping to six feet six inches in front. Its length and width will, of course, depend upon the number of birds and the variety. A house twenty fect long and ten feet from front to back, divided into four houses, each five feet by ten, would give ample accommodation for twelve breeding pairs of such birds as Carriers, Dragoons, and Show Homers, that is three pairs to each division. Of the toy or smaller varieties, each of such divisions would accommodate five or six breeding pairs. At one end of this house should be a door, and there shottld also be a door in each of the dividing interior walls, so that the owner could enter at one end and walk right through.

\section{HEIGHT OF FLIGHTS.}

The flights should be as high, or a little higher, than the back of the house, and extend from the lean-to wall to whatever distance in front of the house there is ground available, say, six to ten yards. The reason why the flights should extend over the top of the house is that birds delight to walk about and sun themselves on the top of a roof, and it is conducive not only to their happiness, but also to their health. The woodwork of the flights should be strong, and the corner posts should 
be at least four by three, and, if possible, should be each cut out of a straight young oak or elm trce, so that the part which goes into the ground may be in its natural condition-that is, with the bark on. If this is not possible, then some extra pieces of wood should be nailed on that portion of each post which is sunk

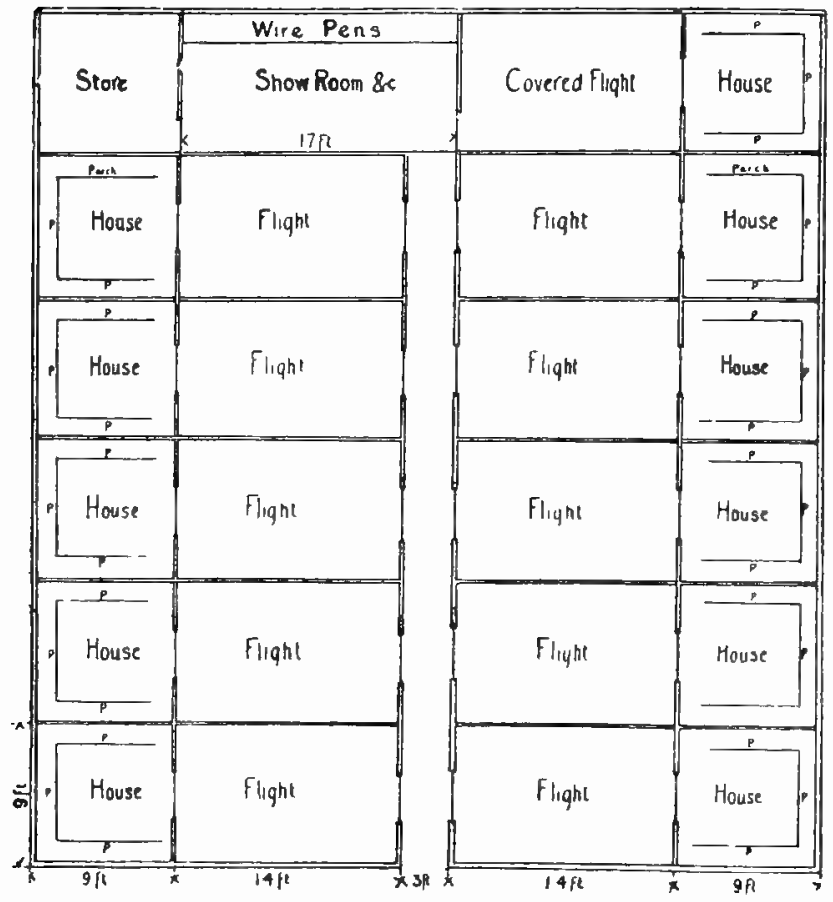

Ground Plan of Mr. Richard Woods' Aviaries, at Mansfield.

in the ground, and it should be well tarred, or treated with some preservative beforc being put in position. The side stays need not be so strong; 1 1 . 2in. by 2 I 2 in. will be ample. Each flight should be titterl with a door close to the house so that it is possible to walk right through the range without coming out; and in addition each one should have its own separate entrance at the 
end furthest from the house. The whole should be covered with strono one-inch mesh wire. In fixing the wire have plenty of side rails and tol rails; if this is not done the wire will sag and bend, and not last a quarter of the time it will if drawn hard and taut. I have said the whole of the flight should be covered with wire. This is hardly correct, as about three feet from the ground should be boarded, or covered with corrugated iron sheets. If the wire is tarred it will add to its strength and lasting power.

\section{COVERING THE FLOORS.}

As a covering for the floors of the lofts, there is nothing superior to two or three inches of coarse pine sawdust. If only a scanty covering is put down it flies all about the place, gets into the eyes and nostrils

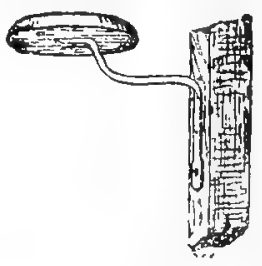

Elbow or Bracket Perch, for Tumblers, Magpies,
Nuns, etc.

of the birls, and often causes serious irritation and inflammation of the organs of sight and breathing. The ground in open flights should be dug out to the extent of three feet, and the hole filled up to within a foot of the top with coarse broken clinkers or bricks, then should come nine inches of coarse gravel, whilst the surface three inches should be fine white or yellow sand. Care should be taken as to where the sand comes from, because if it is ironstone sand it is apt to soil birds of delicate plumage. Where it can be obtained there is nothing to surpass as a top layer sand from the seashore, for in addition to making a nice covering for the flights, it contains much in the way of lime and mineral salts which are most beneficial to 
the birds. The top layer of sand should be swept occasionally, and renewed at least once a year. If ordinary sand is used it is most valuable for the garden when it is removed from the flights.

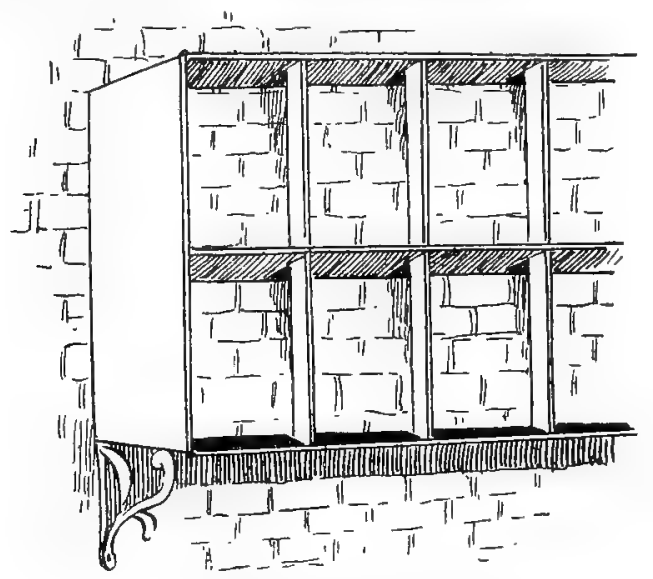

Perches for Carriers, Dragoons, and show Homers.

INTERNAL FITTINGS.

Different fanciers have different ideas as to the manner and method of fitting up a Pigeon loft. Some like bracket or elbow perches, and they are the best

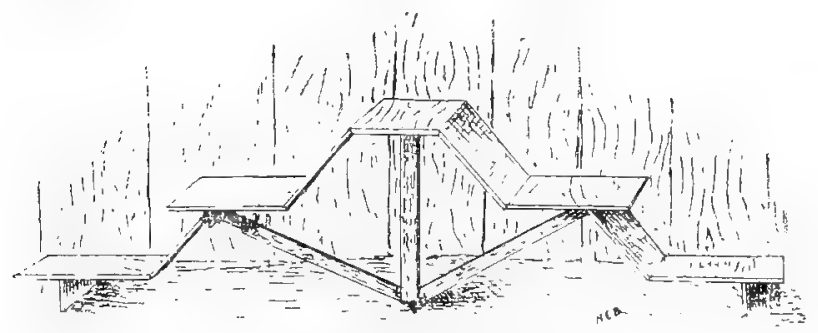

Platform Perch, suitable for mutfed Tumblers,
Fairy Swallows, etc.

for small bircls; others fix perches, which are like a capital I inverted; others prefer box perches, for all the 


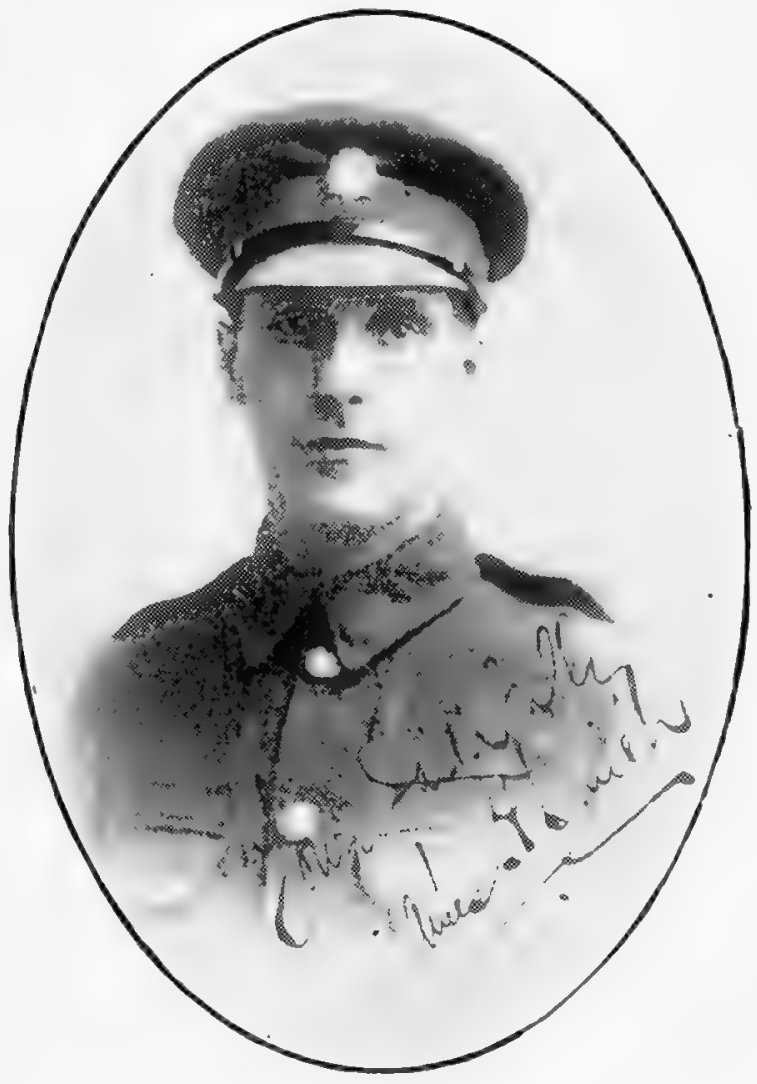

Mr. James H. Smith.

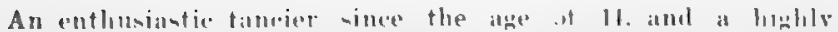

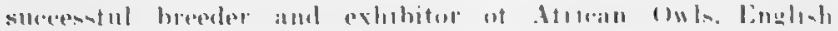

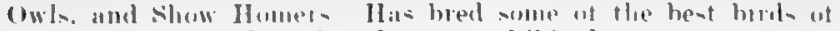
these breeds ever exhibited. 

smaller breeds. For Carriers, Dragoons, Antwerps, and Show Homers box perches are much the best, but they should project some distance from the wall so that the birds may stand facine the window and door, and all their excreta drop behind the perch. Box perches which are fixed flush with the wall are always dirty, because the excreta is dropped on them owing to the birds standing sideways. Another objection to the box perch which fits close to the wall is that birds damage their plumage considerably. The reason why box perches are to be preferred for the breeds men-

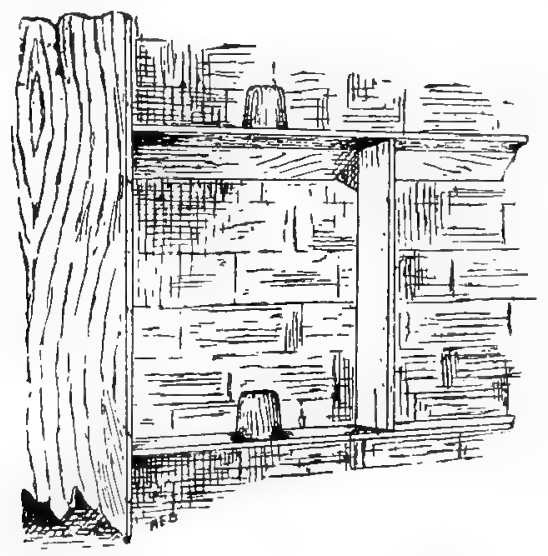

Perch suitable for Pouters and Pigmy Pouters.

tioned is becalse they are more or less quarrelsome and pugnacious, and the divisions between each perch prevent the birds interfering with each other. For Pouters, Pigmy Pouters, and Trumpeters a shelf perch is the best; that is a good broad shelf projecting some eight or nine inclies from the wall. On such a perch the foot feather is not so apt to become damaged. 'The same kind of perch is useful with other muffed-legged breeds such as Swallows, Fairy Swallows, and Muffed Tumblers, as is the platform perch also shown in one of the illustrations. 


\section{NEST BOXES.}

I an altogether opposed to fixed nost boxus. They are not easily cleaned, and are propagators of vermin and disease. In a fixed range of nest boxes if infections disease of any kind nikes its appearance the whole range is infected, and must be pulled down and Aestrored. Further, fixed boxes, especially when some height from the floor, have other serious disaclvantages. Hens, when ahout to lay, are often unable

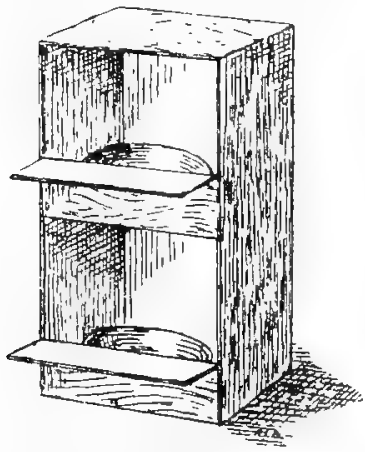

Open Nest Box, with Upper and Lower Compartments.

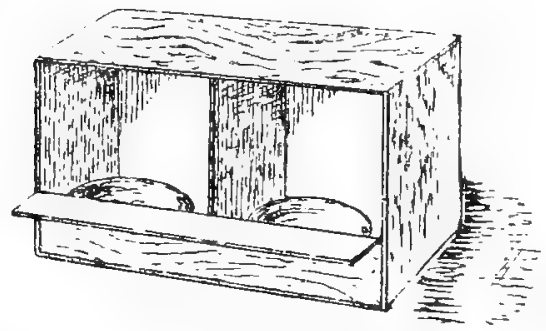

Open Nest Box with Division on Floor Level.

to reach their box and lay on the floor, or they injure themselves in their attempts to reach the box. Again, if a youngster falls out of such a box the jar when he reaches the ground oft knocks the life out of his body, or else breaks a limb. Portable nest boxes are, I am firmly convinced, much the best to use. Each pair may have a double box about two feet six long and sixteen inches deep, or two single boxes of smaller size. These comprise all the internal fittings needful i11 a Pigeon loft. Nest boxes should only be there in the breeding season; removed at the end of that season, thoroughly cleansed, allowed to remain exposed to the meather for a few reeks, then scrubbed, dried, and put away till the following spring, or else broken up for firemood. If specially made boxes are preferred, then I advise that they be well painted inside and out, 
say three coats, and given one fresh coat after each autumnal cleansing.

In the flights the best kind of perch is a long narrow shelf running the whole length of the flight on either side. This shelf should be about 3in. wide, and one inch in thickness. Such a perch may be affixed to the framework of the flioht by iron brackets, but should be kept off the wire or the birds' tails may get damaged.

\section{AN OLD IDEA.}

Moore's " Columbarium," published in 1735, gives the following on "The Method of Building a Loft" "A Pigeon Loft ought to be built to the South or Sonth-West, the Sun lying warmest from those

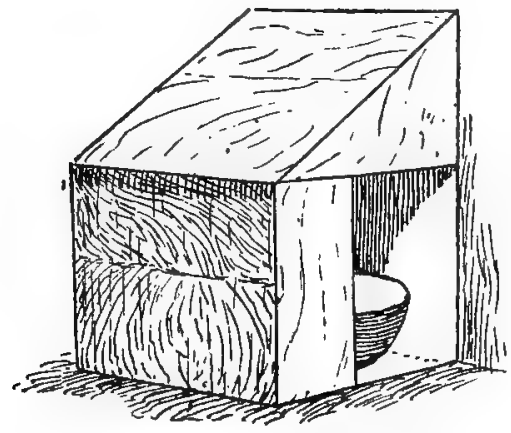

Nest Box for Corner Position.

Quarters; but if you have not that Convenience, you may make a Hole in the Roof of your House, and there lay your Plat-form, smaller or larger as you think proper: A Carpenter that is used to such work will put you in a Method, always remembering to erect proper Works to keep off those tormentors of the Gentlemen of the Fancy, the Cats, for in one Night's Time they will make a very great $\mathrm{Havoc}$, and are generally observed to destroy those Pigeons which you most value; so that 'tis better to be at some Charge at 
first, to prevent the Incursions of such dangerous and fatal Invaders, who seldom or never give any Quarters. Let your Loft be large enough to contain the Number of Pigeons you intend to kee1, always allowing at lcast two Holes or Breeding Places for every Pair; for the more Room they have, the more quiet they will sit, and breed the better."

This is the advice Moore gave to his readers. There is certainly not mich wealth of detail, but there is much common-sense. A South aspect is, indeed,

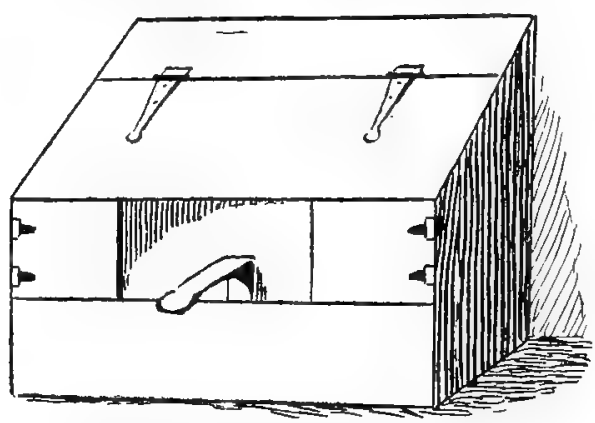

INest Box, with sloping Roof,

Designed and used by Mr. Richard Woods, for cuse of Dragoons, Carriers, and other breeds inclined to be pugnacious.

good. Pigeons love the sum, and invariably do well in a loft which is exposed to its power. The ideal aspect is South-East, as the bircli get the early 1norning sun, and this is a great help in the breeding seasonl.

\section{NEEDFUL IMIEDIMIENTA.}

Amongst things needful in the Pigeon loft are nest 1rans, and these should be of good size (many cases of crooked breasts are caused by the nest prans being too sma11), and drinking fonntains; the more simply made the better. Nerer use a fountain which is not easily cleansed. Long-handled and short-handled sweuring brushes, a three-comered serajer, a short-handled shovel, a sieve for riddling the sawdust on clearing-out 
days, and a finer onc tor use with the corn every day, scparate corn bins for peas, tares, wheat, dari, maize, and canary seeri; baths-I like zinc baths, 3in. or tin. iin depth, 20in. long by 15in. wide, with a 3in. flange all round; thesc are easy to handle and keej clean, whilst the flange is useful to keep the water from being thisown all over the loft or flight floor, and to aftord a resting place for the birds so that they may shake themselves on leaving the bath. Two or three small sionges (these are most useful); a pair of small tweezers a pair of large, and a pair of small scissors, a ball of twine, a bottle of tincture of arnica, a bottle of iodine, a tin of Ejpsom Salts, a box of zinc ointment, a bottle of glyccrine, a bottle of Sanitas or Condy's Fluid, and the show baskets, are all things which should be kept in the pen room.

\section{THE PEN ROOM.}

In a large loft the pen room will be part of the range, or a small house by itself. It should be fitted with good broad shelves so as to accommodate a walking pen or two, and a number of ordinary show pens. If the stud is only small, or if the outdoor accommodation is of a circumscribed character, then the penroom must be in the owner's dwelling house. Every stud, big or small, needs a pen room of some kind or other. It is impossible to select birds for showing or breeding unless they can be penned side by side. Again, such a room is most useful in case of temporary indisposition. A day or two in a pen, and the application of the ordinary remedies will often prevent a serious and possibly fatal illness. A pen-room allows of many things being done which could not be done without it, and adds considerably to the pleasure to be derived from a stud of birds. 


\section{CHAPTER II. \\ SELECTION OF STOCK.}

The reason so many fanciers fail in Pigeon breeding is because they start wrong. Two great mistakes are made by new hands. The first is, that they invariably overload themselves-that is, overstock their aviaries. They buy a lot of birds thinking they stand more chance of breeding winners than if they only have a few. They overlook two very important considerations. The first is, that the best bird of the year in any given variety can only come out of one egg; and the other is, that quality should at all times be preferred to quantity. No fancier should at starting select more than three or four pairs of birds. It takes some time for one to become accustomed to the needs and desires of a stock of Pigeons, and 1 t is impossible for a new hand to successful look after a big stud. Another mistake is in thinking that all one needs to do is to buy a number of high-class birds, great winners, pair them together, and straightaway winners will be produced. Those who have had experience known only too well that such methods invariably bring failure. To become a successful breeder of Pigeons one must serve a fairly long apprenticeship, and possibly come through much disappointment and vexation ere the goal is reached.

\section{HOW TO REACH THE GOAL.}

The first steps are most important, and it is my wish that students of "Pigeons, and all about them," should made their first steps upon a firm and clear roadway. Before commencing to kecpr Pigeons, that is high-class ones, the would-be hreeler should risit a few shows, gain some knowledge of the different hreeds and the differences between them This will enable 
one to decide upon a breed most suited to the conditions under which one will be forced to follow the pursuit of breeding. Then betore deciding to make a plunge the advice of some experienced fancier should be sought, as to the best and most suitable breeds for the personal conditions. If no local fanciers are to be got hold of, then a letter should be addressed to the Editor of "Pigeons," giving full particulars of the accommodation, what money is to be spent, what the atmosphere in the neighbourhood is like, and anything else likcly to be of use to him in answering the question as to which breed is the most suitable under the circumstances.

\section{BREEDS FOR DISTRICTS.}

Too little thought is given by fanciers as to the breecls most suitable for the district in which they live, or to the acquisition of their initial stock. If it were otherwise we should not find, as we often do, so many of our roung hands " clearing' out " year after year as they do. When a young fancier comes in he should clo so with the idea of staying in. No good can come from breeding one season a few Jacobins, then throwing them up for Show Homers or Magpies, or something else. This question of beginning rightly or wrongly has not received from writers on Pigeons that amoun of consideration it should have done. It is often said of some fathers that they have forgotten they were ever boys themselves, and thus have no interest in, or sympathy with, the doings of their sons. So it is with minany writers on Pigeons. They seem to take it that it is unnecessary for them to go into the elementary details of breeding and management, as they are well known and understood. Yes, they are, by those who have been rioht through them, and emerged on the top triumphant, but they are not understond by those who are just beginning to flounder about in the intricacies of Pigeon-keeping.

\section{INPORTANCE OF A GOOD START.}

A good start is half the battle, and I want the youngsters who rearl this chapter to make that good start. It will save them not only much worry and 


\section{Pigeons and Ali Abott Them.}

much disappointment, but also some considerable amount of pocket money. Before purchasing the initial stock I would advise every beginner to think well as to which varietr he likes best. Having made 11) his mind on this point, he should consider next if the accommodation at his command is suited for the rariety which he has fixed upon, because if not, he must endeavour to foster a love for a breed which will fit in with his surromndings. As an example, it would be useless his attempting to breed such birds as White African Owls, White Fantails, White Jacobins, or Magpies, in a small hack-yard loft in a large town. He would never be able to keep them in the spotless purity of plumage in which such breeds need to be kept to be secn to advantage.

Again, in the far North, heavy wattled birds will not do as well as in morc Southern neighhourhoods. The reason why Ireland has so lono been pre-eminent in the culture of such birds as 'Trumpeters and Jacolins is becanse the mild humid character of the climate in the Emerald Isle is particularly conducive to the excessive growth of feather. 'Thus it would be folly for anyone living in the mild, humid, relaxing atmosphere of such places as Torguar, Bournemouth, South Wales, South Derour, and Cornwall, to hope to compete successfully in the production of stuch birds as Show Homers, Antwerps, and Dragonns, with breeders living in the more rigorous climate of Yorkshire, Lancashire, Durham and Northumberland. 'The mild, soft atmosphere would encourage the growth of wattle and cere too much, and render both too soft and flabby. Yet such districts are most admirably suted for such breerls as Carriers, Trumpeters, Jacobins, Fantails, Muffer Tumblers, Swallows, Blaze-faces, etc., hecause what is a clinatic disadvantage in relation to the former breeds, becomes of real assistance in the growth of the essential show yroperties of the latter.

\section{FOR TOWN DWTEILERS.}

Then, whilst the immediate ricinity of large towns is not conducive to successful keeprine of bircls with white, or light, plumage, it is suitable for hirds such as 


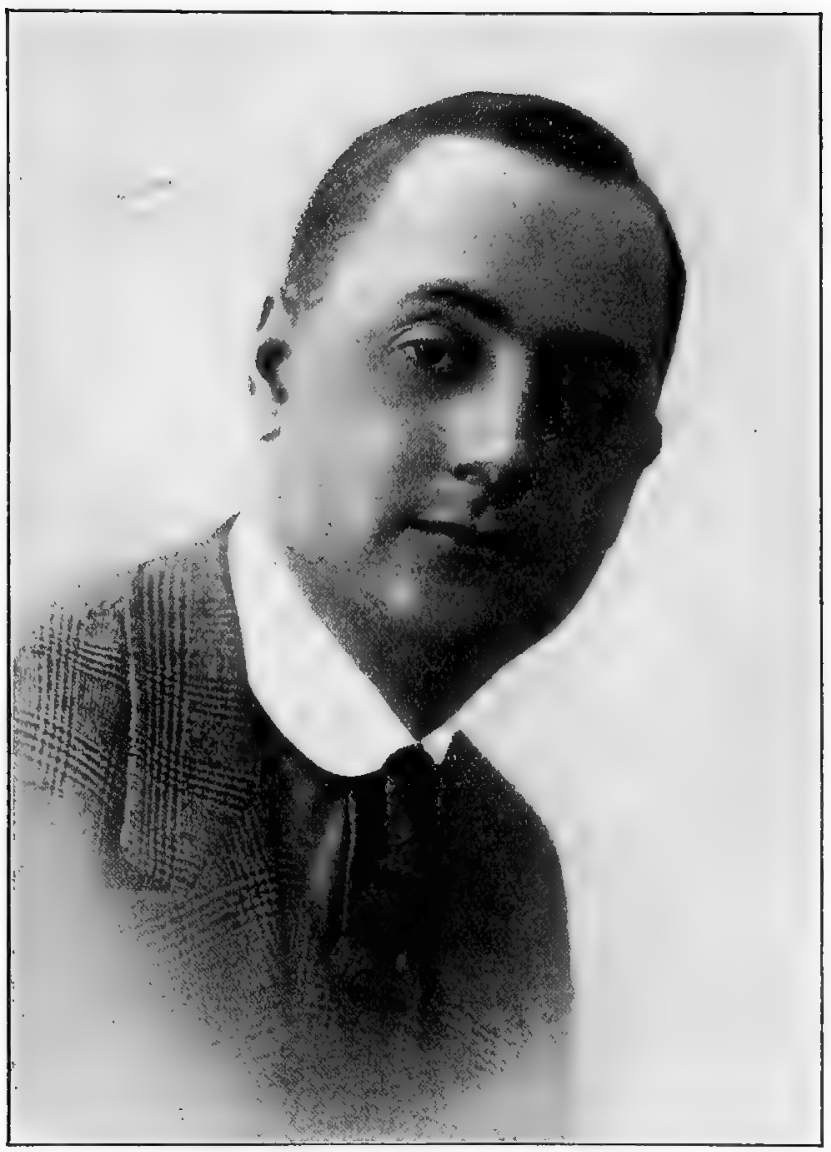

Mr. W. Watmough.

Former Editor of "lrireons and Pigeon Vurld." Author of "l'inem Keeping for Beginners." General Manager of the Fincier, Newspajer and treneral Printing and I'ublishing ('muluny, Ltd. A succesiful breeder, exhibitor, and judge of English and African (owls. 

Black African Owls, Black Tumblers, Black Jacobins, Archangels, Chequet Dragoons, Chequer Show Homers, Black and Mottled Trumpeters. Again, a loft situated in an open spot in the South or West of England, with little or no protection from the blazing rays of the sun, would be most unsuitable for such breeds as Red, Yellow, and Cream Magpies, Red and Yellow Tumblers, Red and Yellow Owls, because the all-powerful rays of Old sol would quickly bleach and ruin their coats.

In a small country town, or village, where there is little dirt and smoke, birds of white, light, and delicate plumage mas te keyit with ease, comfort, and pleasure, but for dwellers in large towns to keep such is the height of folly. They can never houe to successfully compete with their more favoured bretliren, whose lives are cast in more pleasant and favourable surroundings, because no matter how good a Magpie, a. White Jacobin, a White Fantail, or a White Owl may be in actual structural and feather properties, it can never show its natural beauty to advantage against the country-bred bird, because cleanliness has much to do with beauty.

From this it will be seen that if success is hoped for, considerable thought must be given to one's surroundings ere finally deciding which variety to keep. Thus, whilst the cold, bleak North is just the place to keep such breeds as are apt to grow too much wattle and cere, its cutting winds which mean success in tightening and hardening wattles and ceres would effectually prevent the full fruition of the beauty of feather needed in the long and softer feathered breeds. After reading these notes it should not be difficult for the veriest novice to decide what kind of Pigeon is likely to do well in his particular district.

\section{HOW MANY PAIRS.}

Having decided upon the breed, the next question is: How many pairs? This is generally decided by the accommodation at hand, and, as a consequence, failure speerlily comes. Most young fanciers like to see a bird on every perch; vacant perches are an eyesore to them. They want to see a lot of birds about the 
place. It looks well it anyone comes to see the stud! This is a big mistake in many ways. Visiting fanciers would nuch rather look at and handle one or two good birds than a dozen second-raters. It is a mistake for a young fancier to overload himself; he will get more rcal pleasure from two or three pairs of birds than he will from a dozen. With only a snall number he can learn much more than it he is overloaded. Again, sceing that with most young fanciers money is a very important consideration, it is far better to put the same amonnt of money into two lyairs of birds than into a doze11.

"Quality, not quantity," should be the motto of every asjirant to fame on the show bench. The challenge culp winner of any breed can only come from one egg, and that it is just as likely to come from the one egg laid by a hen owned by a novice as it is from one of those owned by a champion exhibitor, " provided alwars and at all times," as the gentlemanl learned in the law say, the quality is there.

It must not for one moment be suiposed that our leading fanciers breed all their winners, even though they have such tremendous studs. 'They do not. I know of several champions which have won high honours at the Dairy, Palace, and Specialist Club Shows which have not been bred by the men who now own them, but by small struggling working-men fanciers who have received from the big guns a good price for the flower of their flock ere parting with it to the big exhibitor. But the big exhibitor would not have required such had they not possessed quality. The lesson to be learnt from this is-With all your getting, get quality.

\section{HOW TO OBTAIN THE BIRDS.}

Having decided wlich variety he intends keeping and how much money he will spend-the latter is quite as important as the former-the young fancier should seek out the best breeclers of the particular breed that he has decided upon. The best way to do this is to read carefully the show reports appearing in tho pages of "Pigeons," also the advertisenents of the particular 
variety. If you are living in a country district away from any other fanciers, you will have to rely entirely upon your own judgment in selecting a breeder to whom to apply. But should it happen that you are resident in a district where a number of fanciers reside, it will be wise to consult them, and ask their advice, not only in deciding whon to get birds from, but also in the choice of a variety. They, with their knowledge born of experience, will be able to give sound adrice on both points.

\section{A FANCIER'S HONOUR.}

The decison having been made, as to the breeder and the breed, you, nyy young aspirant for fane, should write to the fancier you have selected, and place yourself unreservedly in his hands. Tell him how much money you have to spend, also that you know nothing whatever about the breed, and wish him to do his best in mating you up onc, two, or three pairs of birds as the case may be, to the best of his knowledge and ability, and with a view to their producing something which may be able to give a good account of itself in the show pen. By so doing you are almost certain to get better served than if you approach the big breeder nil his nw level, pretending to know all things when you know little or nothing. Most breeders, when put on their honour, will give a new hand a bit more for his money than they will the man who knows as much as themselves. Not infrequently have I known fanciers, having sold a roung hand a pair of two of birds, and given him full value for his money, to at the finish give the young beginner a pair of birds for luck.

The great advantage of going to a man with a name and reputation to sustain is that he is not likely to do anything to besmircl his fame, also that the birds secured will be of one particular family and thus more or less related. This is a most important factor in the success of a loft. Gencrally speaking, it is useless expecting to breed winners if the stock birds are unrelated.

\section{HOW NOT TO DO TT.}

Some short time aoo I was consulted by a wellknown Southern exhibitor as to the selection of a hen 


\section{.32 PigeONS AND AlL ABOUT THEMI.}

for a first prize cock which he had claimed at the Crystal Palace. To aroid the use of names, and the riving of free advertisenents, I will refer to individuals fy the letters of the alyhabet. The bird my frienct had clained was shown by $\mathbb{T}_{-}$- and when he spoke to me he said, "Now I shall want a hen for this bird, shall I get it from A-, or B ?" naming two well-known breeders of the variety. I replied, "Look here, old man, rou have, to $\mathrm{mi}^{*}$ knowledge, been breeding for nearly twenty years, and you have nerer bred a winner yet. Vear by year you purchase winners from Tom, Dick, or Harry, and go to Harry, Dick, or Tom for hens to pair with them. Now, if you have claimed II.'s hird, why not writc to $\mathbb{I V}^{\top}$, and ask him for a hen that will matc with it, and not go introducing strange hlood again? You have year after year gone on this foolish plan, and never had any pleasurt or satisfaction, whilst the amount of money your have rasted is enornrous."

\section{WHAT OFTEN HIPPENS.}

My friend does not stand alone. There are scores, aye, hindreds of others like hims. Ther have an idea that if they r archase their cocks from one breeder they must go to another for their huns. Sc1dom, indeed, does such a procedure bring success. When birds are somewhat related the chances are that they may hit and produce progeny erual, if not actually superior, to themselves. But when birds absolutely murelated are int together, the cliances are a hundred to one that they will not hit. It does occasionally happen that when hirds are paired togcther, crow though they he of the same strain, or family, that the result is not what is expected or desired, though the parunts are really good hirds. When this does occul the roung hand is apt to liscard the progeny, and the oli hirds as rell. This is fonlishness, or worse. The ronng birds having been tred from birds of high merit, must, of necessity, have in their veins the same hlonl and the same properties as the birds they have come from, cren though these good properties have not shomn themselves. In the general and ordinary way the young hand is disappointed with his young hirels, and 
as they are not so high in standard merit as his old ones, he sells them, and possibly the old ones, too. He sells at a sacrifice, and purchases again birds of great merit and high price, only to have his musatisfactory experiences repeated. This goes on for another year or two; the young fancier becomes clisheartened and disgusted, thinks he has been deceived, and throws up the Fancy in despair.

\section{THE OTHER SIDE.}

Now it must be evident to anyone who thinks, that two very high-class birds being mated, their good properties must be in the blood of the progeny, even if they do not show outwardly. Therefore, the breeder's task is to bring them out. This can best be done by pairing the best young hen back to her father, the best young cock back to his mother, or pairing two of the young together. It is a hundred pounds to a penny that such mating will bring the desired success, and if followed will prove both profitable and pleasurable, whereas the constant introduction of fresh blood can end in nothing but disaster and disappointment. It stands to reason that such close pairing must not be persisted in, or disaster will quickly follow. The old hand may breed closer than the novice, because he has experience to guide him. Fuller information on this point will be found in the chapter on "Establishing a Strain," and also in my book, "In-Breeding."

\section{VALUE OF PEDIGREE.}

The great value of securing one's original stock from one stud is that one is not so likely to breed a lot of wasters as when the birds are gathered together from all parts of the compass. Well bred second-rate birds-that is, birds just removed from the category of prize winners, will, if related, breed far better stock than a lot of high-priced winners of firsts and specials which are unrelated. It is a hundred to one against the latter producing anything but a lot of wastrels, because having been bred in different lofts they have not been bred upon the same lines. Further, the admixture of strange blood often gives rise to sports. On the other hand, the birds of one strain only once 


\section{Pigeons and All About Them.}

removed from being prize winners, and bred from the same blood, will, if correctly mated, produce stock generally superior to themselves. In mating such birds, one has to carefully blend the excellencies and deficiencies of each in such a manner that they are calculated to produce a perfect whole. This process of covering the weak points in one bird by the strong ones of its mate is deeply interesting, even as it is generally successful. Further, it is the only way in which a strain can be built up and maintained. A stud of birds got together and managed in the manner indicated must of necessity, sooner or later, yield "what's wanted." Time and patience will be needed in the work, but they will receive great reward if perseverance is added thereto. "Rome was not built in a day," neither can a stud be made in a season. But pedigree will tell. The aim and object of the breeder must be to intensify and increase the good points in his original stock, whilst at the same time he eliminates and reduces the bad ones.

\section{FIXING THE IDEAI .}

In starting a strain, a fancier needs to fix the ideal in his mind, and to let nothing turn him aside therefrom. He must keep his mind's eye ever fixed upon it, and plod steadily along until it is reached. In so doing, he must keep a careful record of all his matings, and each season every bird mated u1 should have all its faults and excellencies carefully recorded in the stud book. The keeping of a stud book is absolutely necessary if success is to be achieved. By its aid one is able to avoid making mistakes, because a glance at the stud book shows exactly where the good and bad points in the strain are coming from. Memory is not to be compared to a carefully tabulated record, and the man who trusts to memory will never attain the heights of the Fancy. But with carefully selected, related original stock and a stud register, all things become possible. 


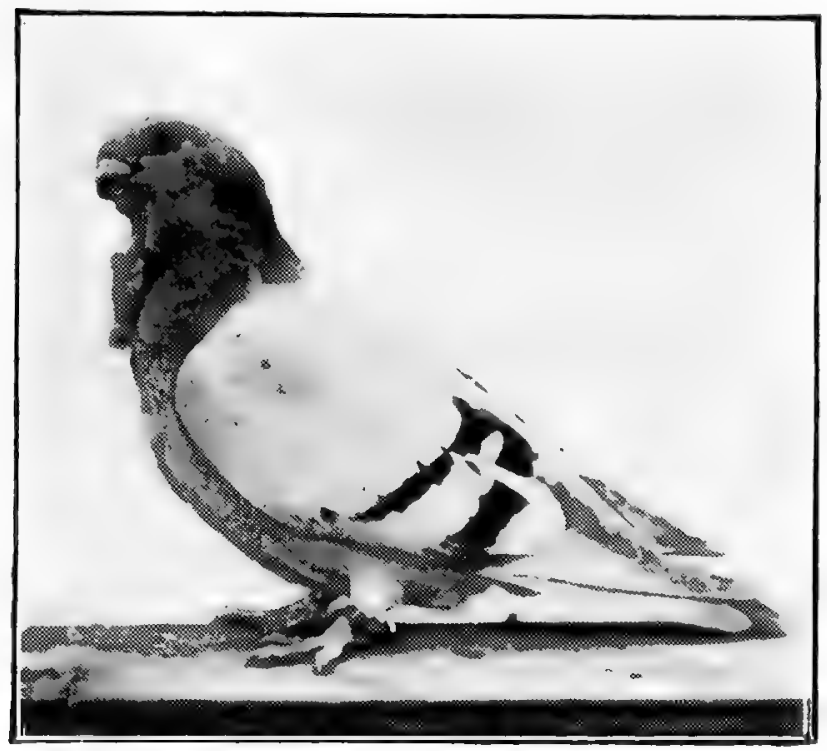

\section{Silver English Owl Hen.}

Winner, as a youngster, of 1st Manchester (F.1).C. Show), and is a descendant of Mr. Brayshaw's famus lisquilant Trophy hen.

The Property of Mr. Harry Tattersall. 



\section{CHAPTER III. \\ GENERAL MANAGEMENT.}

A good start having been made by the purchase of some well-bred stock, it must be followed up by strict attention to the gencral management. Good food, regularity in feeding, plenty of fresh water for drinking and bathing, the provision of grit, abundance of fresh air, and systematic cleanliness are the great essentials to success.

\section{THE FOOD SUPPLY.}

Food and feeding are items of the first importance. Nothing is gained by the purchase of cheap food. Many fail to realise this, and think that anything is good enough for Pigeons to eat. This is a grave error to make. I would impress upon my readers the absolute necessity of using only the best corn. It is cheapest in the end. Many diseases may be directly traced to the use of inferior, unsound, and unclean corn. Regularity in feeding is also essential to strceess. Birds should be fed as near as possible about the same time each day, and the best times for foeding stock birds are about 8 a.m. and 6 p.m. in Summer, and 9 r.m. and 4 p.m. in Winter.

GROUND $V$. HOPPER FEEDING.

When and wherever possible I advocate feeding on the floor of the flight. When birds are fed on the floor of the loft they are apt to pick up bits of sawdust and other matter which is not good for them. If there is no outside flight, and the birds must be $\mathrm{f} \approx \mathrm{d}$ inside, then hoppers should be used; but I prefer hand-feeding to hopper feeding, because one is able then to feed just so much as the birds require. Further, much pleasure is derived by watching the birds as they feed, and should one be looking a bit 
out of sorts, then is the time to see it and attend to it. 'The best hoppers are those of galvanised iron or *uamel ware, with divisions to prevent the birds scattering the conil about the floor. For stock birds

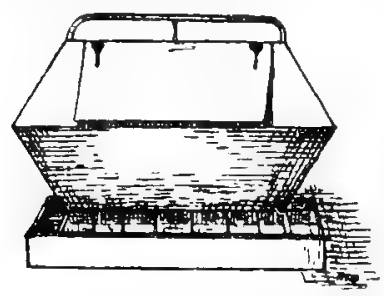

Metal Food Hopper.

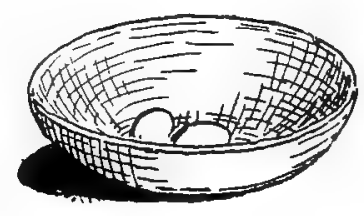

Earthenware Nest Pan

the best gencral feed is maple peas and tares for the medium-sized birds, with the addition of a little dari for the smaller breeds, and some tic beans for the more robust breeds.

\section{DRINKING WATER AND FOUNTAINS.}

The provision of clean fresh water is a point which must receive great care. In winter the foun-

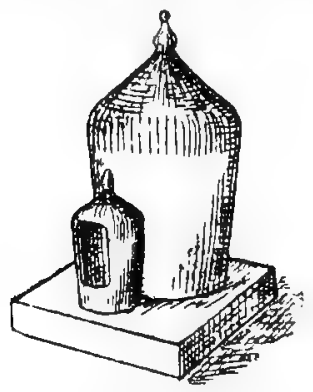

Stoneware Fountain.

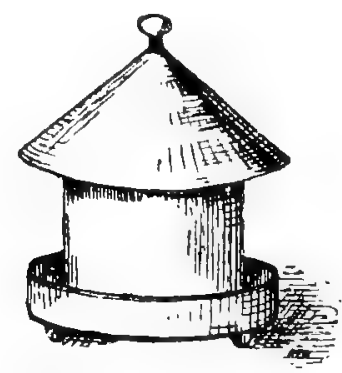

Covered Enamel Fountain.

tain should be filled regularly every morning, and in summer time twice or even thrice a day should the fountain be re-filled. There are fountains of all kinds, shapes, and sizes on the market, but the best are the round enamel ware ones. Stoneware is apt to chip 
and break, especially in frosty weather, and the majority of them are not so easily handled, by reason of their weight, as those made of iron and enamelled; neither are they so easily cleansed. The fonntain should stand in the flight in a shady corner, so as to keep the water cool. Sun-warmed water is apt to cause diarrhoea. Further, the water is not so likely to become fouled as if placed in the loft. In the loft, sawdust, dirt, and dust are all apt to find their way in to it.

\section{THE ORDER OF THE BATH.}

Many fanciers are apt to undervalue the importance of the bath. I may tell them that if Pigeons are to be kept in good health it is of the most vital importance that they should be allowed to bathe freely. This fact is not sufficiently appreciated and recognised by fanciers, and many who attend well to

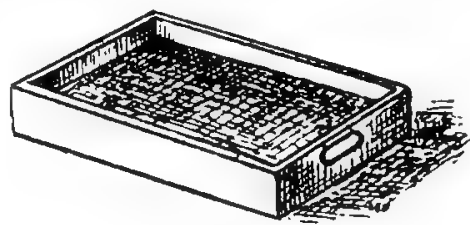

Zinc Bath.

other details of management ate apt to be lax about the bath. Water is cheap enough, and, generally speaking, plentiful enough. Therefore, there is neither sense nor reason in withholding it from the birds. In summer most Pigeons will, if given the opportunity, bathe every day, and in winter time every other day, and they should be given the opportunity. One of the first symptoms of a bird being out of sorts is a refusal to bathe, and birds which do not bathe should be examined and watched carefully. I have, in speaking of the utensils needed, described the form of bath which I favour. Pigeons delight in the tub. They are amongst the cleanest of animals, and the pleasure and enjoyment they receive from being able to indulge in the luxury of a good bath is 
great. When birds are in good health they go boldly into the water, opening their wings and splashing like a lot of kids bathing on the beach. They lie in the water, allowing it to permeate their plumage and loosen the dirt and scurf of the body; and in a little while a bath soon has the appearance of containing chalky or milky water. No better proof could be given of the necessity of the bath for Pigeons. A final word of warning. Remove the bath immediately the birds have finished their ablutions. If this is not done some of them may be tempted to drink from the bath instead of the fonntain, and thus take into their systems the dirt which is floating on the top of the water.

\section{GRI' AND ITS USES.}

This is one of the things Pigeons cannot do without. Grit, in some shape or form, is absolutely needful to their welfare. Sharp, flinty grit is needed to assist them in the digestion of their food, and to keep their bodies in good health. With the grit should be given salt, and most of the grits which are now

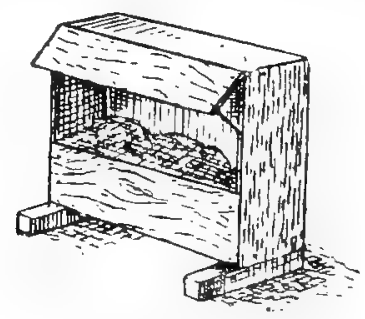

Covered Grit Box.

specially prepared for the use of Pigeon fanciers contain salt in some form or other. Lime, too, is needful to assist the hens in preparing the matter with which to shell their eggs, whilst for the young birds it provides matter for the building up of bone and feather. Old mortar used to be in great request by Pigeon fanciers, but I would warn my readers against using this. Mortar is not now made like it used to 


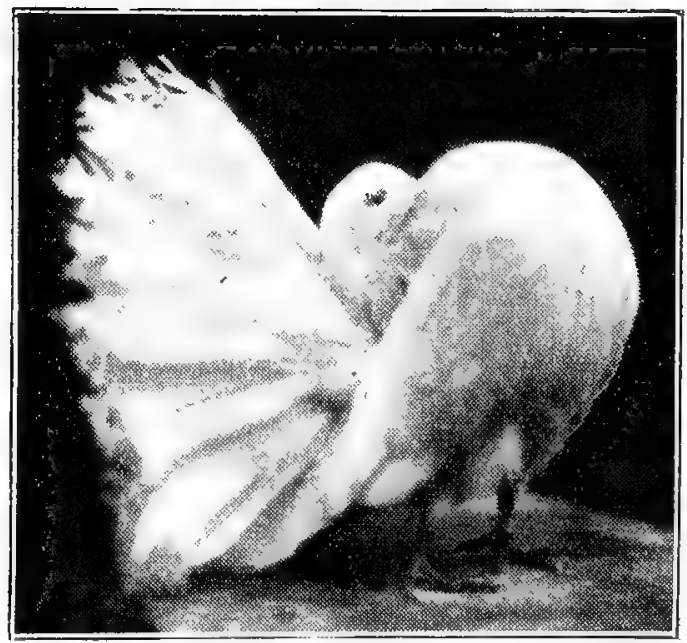

White Fantail Cock, "Dandy Prince."

Winner of 1 st and spl. hest cock Middlesex Colmmbarian Society's Show, 2nd Fantail Club Show, ete.

Bred and Exhibited by Mr. H. Thurston-See. 

be, and dire results may follow the using of it. Further, there is no noed to run risks by using nuatter about which nothing is known, when by the cxpenditure of a few shillings enough grit, properly medicated and salted, may be obtained to last a large stud the year round. Some prepared grits contain more salt than others, and if it is thought that more salt is required by the birds, then they may be given a lump of rock salt to lick. This, like the grit, should be placed in a wooden box. 'This grit box shoukl be placed in a corner of the flight under a cover, so as to keep it clean and afford protection from the weather. A word of warning as to the use of salt. Too much is as bad as too little. It impoverishes the blood and causes the feather to be thin, harsh and brittle.

The loft should be cleaned regularly and systematically. If possible, all droppings under the perches should be removed daily; and once if not

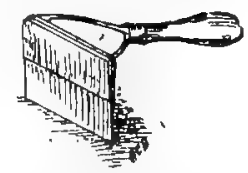

\section{A Useful scraper.}

twice a week the perches should be scraped, and the sawdust on the floor riddled so as to remove the loose droppings which it may contain. When the cleaning is done regularly it does not occupy much time, and it is astonisling how quickly a handy man can clean up a loft; half-an-hour a day spent in this manner will accomplish great things. A clean loft means a healthy loft, and a healthy loft means a successful loft. A dirty loft breeds vermin and discase, and where these are there cannot be successful results.

\section{OBJECTIONABLE VISITORS.}

Cats, rats, and mice are all enemies of Pigeons, and have to be guarded against. In lofts which are raised from the ground there is little to be feared from 


\section{Pigeons and Ali About Then.}

rats and mice, but in brick buildings, or those which rest on the ground, they are apt to make their appearance, there a watch must be kept so that if either make their appearance, measures may be immediately taken for their extermination. Rats will boldly attack and carry off young Pigeons, whilst they, and mice, too, foul the food if they come in contact with it, and many cases of diarrhnea, and other diseases, may be traced to this canse. Nowadays there is no need to lay down poison, which the hirds may get at as well as the rats and mice, but no harm can result from the use of Liverpool Virus, which spells death to all such gentry, and is easily prepared and laid about their runs. 


\section{CHAPTFR IV.}

\section{BREEDING.}

To the ardent fancier the breeding season is the season of the year. It may be a time of anxiety, expectation, and vexation, yet it is also a time of great joy, pleasure, and delight. Great, indeed, are the fascinations of the breeding season. To the true fancier no season brings such joy and pleasure. Even to the hand bitten show-goer the delights of the breeding season are keen. Many a time have I heard an old warrior exclaim that he derived far mote pleasure from his birds during the breeding season than he did at any other time of the year. The best way to secure all the pleasure that this most interestjng of times can give is to so prepare and carry through its work that it shall at least deserve, if it does not bring, success.

\section{MAKING READY.}

In preparing for the breeding season the first thing to do is to give the Pigeon house a thorough clean out from top to bottom, like a good housewife does her spring cleaning. Many people do a lot of work with the whitewash bucket and brush at this time, but I am no advacate of whitewash at this season of the year. Pigeons don't like damp, and it does not like them. They can stand anv amount of cold if it is dry, and their house is snug and dry, but damp and draught will soon play "old Harry" with them. The spring cleaning which I recommend consists in first removing all perches, then sweeping the roof and walls well and thoroughly with an ordinary house broom, and the carrying away of all soiled sawdust. This done, the walls should be given a good dry scrub with a scrubbing brush and a bucket of clean sawdust. The brush should be dipped in the 
sawdust, a certain quantity of the sawdust brought out of the pail on the face of the brush, and the walls well scrubbed and rubbed with the brush and sawdust. Each dip of the brush should cover about two or three feet of the wall. It is astonishing how clean a loft wall may be made by a dry scrub. The walls having been done in this way all round, should again be swept, as should the floor, and all the dirty sawdust used in the scrubbing process taken away. Following this, the floor should be covered with two or three inches of clean, coarse, sawdust. A dry, fine day should be selected for this cleaning down process, so that the birls may be turned into the flight whilst it is going on.

\section{BRINGING IN THE BOXES.}

I have expressed ny preference for dry cleaning of the walls over the white-washing method, and it nuy be as well to give the why and the wherefore. In the early months of the year the walls of a Pigeon house, be they of wood or brick, arre naturally more or less danp by reason of the moisture contained in the winter atmosphere, and they will not be dry until the sun obtanins more power. To give the walls a coating of whitewash would make them damper still, and the damp being given off from the walls, whilst the nights are cold, cannot by any possibility be good for the birds. Further, I have known more than one good Pigeon have its cyus troubled by the line coming off the walls. Many believe in the clcansing powers of lime, and that is the reason for advocating its use. It aiso is a good cover for dirt, and causes many a fancier to give his loft what is only a surface cleansing; that is, instead of thoroughly cleansing and sweeping the walls, as I adrise, the orner is apt to take the whitewash bucket and brush, and make a tout of the walls, covering up the dirt instead of taking it off.

The house having been swept and garnished, the perches slould again be fixed, and the nust hoxes brought in. I believe in portable nest box's, and always use ordinary cube sugar boxes. If you are 
dealing with the small varieties, such as Tumblers, Magpies, Archangels, Fantails, Jacobins, etc., one box is sufficient for each pair, but if you keep Runts, Pouters, Carriers, Dragoons, or Show Homers, then two of these sugar boxes will be needed for each pair, and they must be so arranged that each pair of birds will know their own nests, and thus not be inclined to wander away and interfere with their fellows in the loft. If you have a pen-room or a shed where you can fix up a few matching pens such as are advertised in "Pigeons," you need not trouble about doing anything to these boxes beyond nailing a strip of wood along the front, so as to form a barrier or fence to prevent the young birds, when you have any, from wandering away out of the nest. If you have no room or shed in which to mate your birds, or cannot afford the cost of a fiew mating pens, it is wise to put a few bars on the front of each box, and a door, so that the box looks something like a Rabbit hutch. A few laths nailed on with fine $x_{2}^{\frac{1}{2} i n . ~ F r e n c h ~ n a i l s, ~}$ a door with two pieces of old leather for hinges, a piece of wood to act as a button fastener, and the nesting place is complete. What is properly the top of the box becomes the front when the box is laid on its side lengthways, and the sides become the bottom and top. The bottom should be well covered with sawdust, and the birds which are to be mated should be put in together, and kept fastened up for three or four days until they have sworn eternal loyalty and allegiance. The food can be put on the floor of the boxes, and water may be given them in small jam jars o 1tside.

\section{FOR BETTER OR WORSE.}

When they seem to have decided to take each other "for better or for worse," the doors may be taken off, and the birds allowed to come out into the loft. Careful watch must be made at this time to see that they do not break. It sometimes happens that a gay young cock or a giddy young hen will break avay from the partner you have chosen, and go firting with some other bodr and the strange 
thing is that these self-formed attachments of Pigeons are generally speaking, very strong and binding upon the parties concerned. But as promiscuous pairing cannot for one moment be allowed in a well-ordered ariary, the birds must not be given the chance to pick their own partners. Some birds pair up very quickly and readily, and are such good-tempered, sweet dispositioned little creatures that they never cause their master or mistress a moment's worry or anxiety, whilst others are so full of the spirit of contrariness that they mould almost make a saint swear. Still, it is no use losing one's temper in the Pigeon loft. Kindness, firmness, and perseverance bring their own reward there, even as they do in many other things.

\section{A NEEDED VIRTUE.}

Patience! One needs a goodly stock of this virtue at the commcncenent of the breeding season, especially if there are any of these giddy, flighty, refractory birds in the loft. If the bitcls have seltted things nicely ere you let them out, you will have no trouble, but if you sce the least sign of coldness or indifference to the charms of the mate you have picked for any particular bird, rou must at once put them in confinement again. If not, there will be trouble, and a lot of it. Should you have a place in which rou can pen rour birds for pairing, you should, when they are ready, put them all in the loft together and let them select their own nesting places. There will be a few free fights, but you need not interfere unless a couplo of cocks should be extra pugnacious, and feel inclined to fight to the death. This does happen sometimes, but very rarely. Then it does you nulst step in and fasten one pair up in a box, and let the others take the bos orer which the battle-roral arose. It is the cocks, as a rule, which select the breeding place when the birds are turned loose in the loft in this fashion, and it is astonishing how they will fight for possessinn of the hox to which ther have taken a fancy. Speaking generally, cocks which fight well for their homl make most cxccllent parents and good breeders. 


\section{FEED I.IBERALLY.}

When the bircls are first paired up they should be fed liberally upon the best corn. Good, sound maple peas and tares are the best foecl at this time of the year, with the addition of a few handfuls of small maize two or three times a week.

Just a word of caution ere I leave speaking of pairing up. Never pair up any birds that ate not thoroughly fit and ready. All birds should be thoroughly fit, full of life and vivacity, clear in the eye, hard and tight in plumage, bold and vigorous in their movements, clear and bright in their calls one to the other. Nevet pair birds which are dull in eye, heavy and listlass in their movements, and soft and slack in plumage. When birds are fit the results of the breeding season are generally good, but when they are not, one can expect a series of shell-less eggs, unfertile eggs, egg-bound hens, and hens "down behind." The latter is a term used when hens have had such trouble in laying that they have ruptured the ovaries, and have become unfit for breeding. Condition plays a great part in the success or failure of a loft. Get it, keep it, cling to it, and success will be attained and failure avoided.

\section{CONCERNING NEST PANS.}

It is not wise to put the nest bowl into the box immediately the birds are turned dow'n in the loft, as it is apt to make some bircls a little too eager to go to nest. It is wise to "bide a wee," watch the progress of crents, and not to introduce the nest bowl until you see the birds are intent upon going to nest. This you can easily tell by the manner in which the hen is driven about all over the loft and flight br the cock. You need not be alarmed at this driving about; it is quite a natural process, and the cock will not hurt the hen. On the contrary, this "driving to nest," is a wise provision of Nature, and its object is to fit the hen for the task of laying. A hen that is well driven by the cock is seldon subject to egg-binding, the driving having the effect of reducing the flesh on the hen, making the muscles of her body strong, yet 
flexible, so that when she comes to lay she is able to commant the full power of her muscles in the act of roiding the eggs.

When you put the nest bowls in they should be half filled with sawdust, upon which has been sprinkled a few drops of turpentine. The object of this is to koep down insects. On the top of the sawclust should be laid a handful of straw, in lengths of three or four inches. Before putting the straw in the bowl, rub it well in the hands so as to soften it. If this is not done, the eggs are apt to roll about the howl and get cracked, chipped, or smashed altogether. As the bitds themselves like to have a hand in making their nests, a handful or two of this cut straw should be littered about the loft floor. This will afford them amusement, and also keep them steady and occupied.

\section{A TIME FOR INSPECTION.}

Whan you see a hen standing about in the nest bowl after the driving process has been in operation for a few days, you should keep a keen eye on her, and if she has not laid when you shut the birds up for tle night, you should lift her up and examine her carefully to see if she is egg-bound or not. If she is, the vent is likely to present a swollen and distended appearance, and upon pressing it gently you will be able to feel the egg; but if you cannot feel the egg you need not worry, as hens often stand in the nest bowl at night for a day or two before they lay the first egg. I will say more about egg-binding later on. The first egg is ustually laid about four or five o'clock in the afternoon, the next day is missed, and then about one or two o'clock on the third day the hen drops her second egs. During the interval between the laying of the first and second egg the hen will mount guard ove the first egg, but she will not commence to sit until she lays her second egg. The period of incubation is eighteen days. Some fanciers commence their reckoning from the date when the first egg is laid, others when the second makes its appearance. If goul adopt the former prac- 


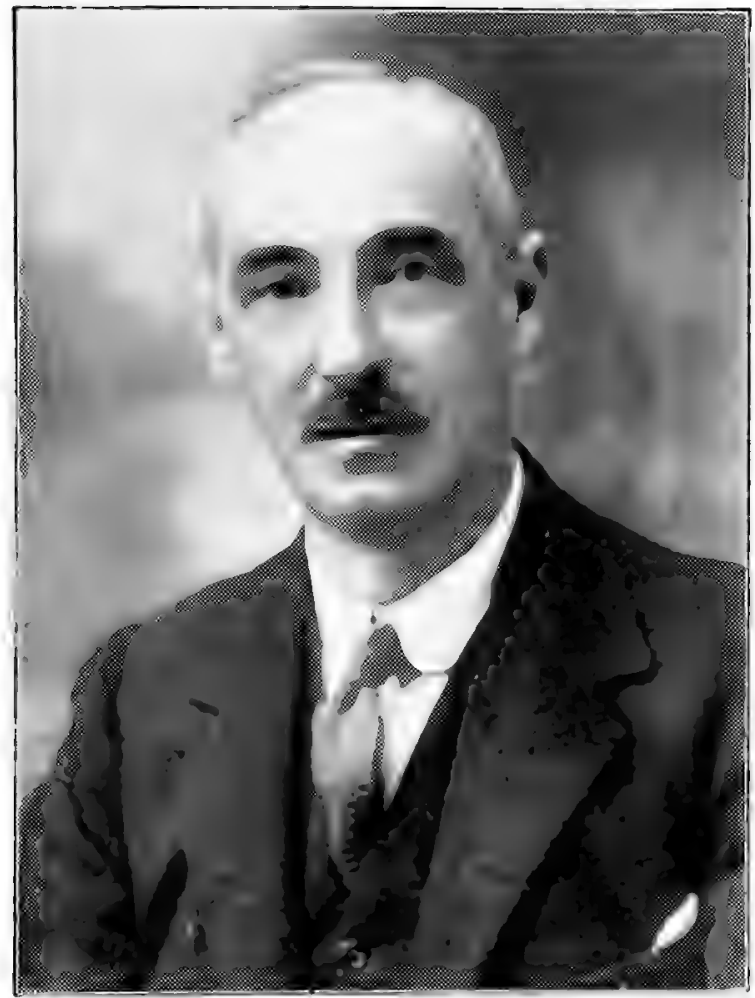

Br. W. E. Barker, M.B., Ch.B.

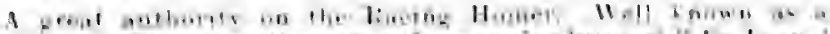

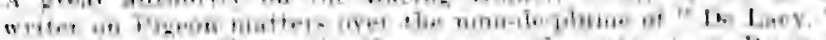

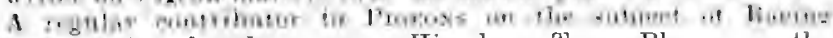
Homers for the show pen. His hen, True Blue, won the

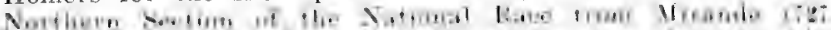

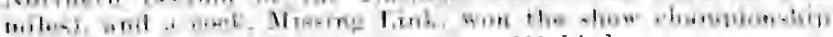
in 1916, beating over 6,000 birds. 

tice, you may expect the young bircls on the twentieth day; if the latter, eighteen days. In the early part of the season the hatching may be, and is, sometimes delayed a day or two longer, and contrariwise in the height of stmmer the young birds chip the shell from twelve to twenty-four hours earlier.

\section{THE HATCHING PERIOD.}

I intend speaking of some more of the troublesome obstacles to progross, and also hope at the same time to show my readers how to avoid them, or to alleviate and minimise the results thereof. The first is a very common trouble, and arises generally from one or two causes. It often happens that an egg gets a slight puncture, or is cracked, during the process of incubation. Sometimes this is caused by the sand and excreta adhering in little balls to the feet of the old birds, which destroys their sense of feeling, and interferes with their turning the eggs properly. If the birds' perches and nest boxes are kept thoroughly clean, and they are given a bath daily, eggs will scldom, if ever, be punctured from this cause. At other times, it may arise through a strange bird invading the nest-box, and wanting to usurp the privileges of its regular occupants. In such cases there is usually a battle royal, and eggs, if not absolutely smashed, are either punctured or cracked.

\section{INSPECTING EGGS.}

The eggs should be looked at once each day, either first thing in the morning or the last thing at night, the latter for preference, because accidents more often happen during the day than they do during the night, and, as a consequence, remedies can be applied more quickly, and evil nesults more often prevented if the diurnal inspection takes place at night. When an egg is found to be either punctured or cracked (that is the shell only, because it is useless doing anything if the inner mernbrane has been ruptured), it should at once be repaired. This can be done in two ways, one by cutting ont one or two thin strips of stamp edging, and sticking them over the 
puncture, or along the line of the crack, or by applying a little collodion to the place injured; the latter dries at once, and forms a complete airtight covering over the puncture of crack; but I prefer the strip of stanp edging myself. Care must be taken in putting on the collodion not to let it run over the outside of the shell; and the strip of stamp edging must also only be of sufficient width to cover and hold the shell along the line of the puncture or crack. If 1 nuch of the outsicle of the shell is covered its porous character is lost, and the roung bird will be suffocated ere it has strength enoingh to get out of the shell. Further, the day previous to the egg being due to hatch it should be soaked for five minutes in warm water, so as to remove the stamp edging. If this is not done it is quite possible the egg will not chip properly owing to the shell being held together by the stamp edging; and thus the young bird will not be able to emerge from the shell, and will be found dead, death having been induced by its hidebound condition, consequent on not being able to cast off the shell.

\section{VALUE OF MIOISTURE.}

Some fanciers sprinkle the eggs occasionally during the period of jucubation, but this is not necessary if the birds are allowed the daily use of the bath. The reason why it is done is to prevent the inner nembrane of the shell from bocoming hard, tough, and dry. When it reaches this state the young bird has a diffeulty in penctrating it when the time comes for the shell to be chipped. In its efforts to release itself from the shell the young Pigeon pecls at the inside of its prison, going all round in a straight line at the bottom of the air space in the top of the egs: If the inner numbrane has become hatd and tough it does not readily respond to the attacks of the little bird's beak; further, it sometimes adheres to the liead of the bird and provonts it working itsclf round the egg. Those who do not sprinkle the eges day by day chring incubation, often soak them for fire or six minutes in blood-warm water the two crenings previous to their being due to hatch. Some, instead 
of soaking them in warm water, hold them in the mouth for a few moments. The idca in each case is the samie, as is the effect-the softening of the inner membrane of the egg.

\section{ASSISTANCE IN HATCHING.}

It occasionally happens that young birds chip the egg, make the first indentation, and then for some reason or other are unable to do more. This generally arises from weakness. When such happens a little assistance is often attended with good results. In fact, one friend of mine assisted twenty out of his first thirty youngsters out of the shell during one season. The young should hatch on the eighteenth day following the day upon which the second egg was laid. Therefore, on the eighteenth day, if an egg is found to be chipped onie may take it that things are going on all right, but, if twenty-four hours after the first little puncture has makle its appearance there is no other break, the owner might try what he can do. to assist in the breaking of the shell. Generally speaking, at the end of the period of incubation the shell is very brittle, and there is not much difficulty in cracking it. A thin, blunt piece of wood or a toathpick should be inserted in the small aperture which the bird has made, and gently lifted upwards and outwards round the top of egg at the line where the body of the bird is lying. This operation must be very carefully conducted, and only the most minute portion of the shell broken at once. Any rough or clumsy treatment will, nine times ont of ten, mean instant death to the young squab. Having broken away a small portion of the shell, moisten the inner portion by applying a little saliva from the tip of your fore-finger. This will prevent injury to the squab by the inner membrane being softence. Often when this membrane is dry and adhering to the body or head of the bird, to attempt to remove it causes the bind pain, and brings away not only the membrane, but some of the down on the squab's head or shoulders as well, and this is not at all desirable. 


\section{DON'T HURRY.}

Having removed a small portion of the shell, and lifted the nembrane, if it has been found adhering to the squab, put the egg back under the old bird, and leave it for about one hout; then have another look. It is quite possible you will find that the slight assistance you gave has enabled it to move more freely in the shell, and that it has gone on with the work of breaking the shell itself. If it has not, you can do a little more, but don't do too much. Don't be in too great a hurry 'to make the youngsters leave. the shell. If it is living and breathing freely be patient, and the chances are a hundred to one on cverything proceeding to a successful hatching. If, however, after several hours you find the bird has made no progress on its own account, you must do a little more yourself. In removing the shell be vers careful to keep well within the line of the air space, and above the heacl of the squab. Should rou get below you are apt to rupture some of the delicate nembranes with which the bird is enfolded, and shoulcl you do this there is small chance of the bird coming out alive. Keep a sharp look-out whilst you are cracking the shell, and should you see the faintest trace of blood desist immediately. But one thing never forget in these operations, and that is, the softening influence of a little saliva.

During damp weather, there is not, as a rule, much difficulty experienced in hatching ont, unless the parent birds are not robust. Then the roung ofter farl to leave the shell because they have not the necessary vigour to burst the wall of their prison, but when strong, healthy birds are paired, it is onlyin very elry weather that there is much difficulty in this matter. Prevention, however, in this, as in all other matters, is better than curc. Therefore, it is, as I have saicl, a good plan to soak the eggs in warm water of the temperature known as blood-hcat. The soaking should take place the lay before the eges are due to hatch, and should last about five or six minntes. There are some fanciers who do not belicte in this soaking of the eggs. They say it is not 
natural. Granted! But what is absolutely and entircly natural in the manner in which domestic Pigeons are bred and reared? Breeding under the artificial conditions we do we cannot ensure natural methods being followed. Therefore, the best we can do is to get as near to them as possible, and when we cannot get as close as we should like, let Art step in to aid Nature. The eggs of wild Pigeons are exposed much more to the dampness of the atmosphere than are those of domestic Pigeons, and the dampness thus denied must be supplied in some other manner. The soaking in warm water I have proved over and over again to be of much service. I have soaked thousands of eggs, and I believe with the most beneficial effects.

\section{A LESSON FROM NATURE.}

That a moist atmosphere is conducive to the successful hatching of eggs has been proved over and over again. In addition to its exposure to the moisture of the atmosphere, the nest of the wild Pigeon is damped and moistened by the parent birds themselves. They have to seek their food among the wild grasses and growing crops, and these at morning and night contain a great deal of moisture, which is to some greater or lessar extent communicated to the feathers of the birds as they seek their food. Again, the birds bathe in the streams in the woords and on the edge of ponds, and bring the moisture back to their nests. This teaches us that during the period of incubation the bath should be liberally supplied to birds which are breeding. Every day should the baths be given. One day early in the morning, so that the cocks may bathe before they take up their position on the nest, and the next day after the cocks are on the eggs. This method ensures cocks and hens getting a bath every other day, and when it is provided in this manner few Pigeons there are that will refuse it. If the bath is given late in the morning the cocks never get the use of it during the incubatory period, and this is a mistake. Further, if it is given early and allowed to remain all the morning. so that the hens may have a turn as well as the cocks, 
the hens get nothing but dirty water to bathe in. This is most injurions to their health. I never like to sele baths in an aviary at all hours of the day. The first thing a Pigeon does when it stands on the edge of the bath before taking its plunge is to drink, and if the hens have the dirty water of the cocks left for them, it of necessity follows that they swallow a quantity of the refuse which has been thrown off the bodies of the cocks whilst they were bathing.

Threefold is the use of the bath during the breeding season, and the fancier who allows his birds to indulge freely in its use will never have cause to regret the same. It makes for health, strength and vigour in the old birds, it prevents the incubation and accumulation of undesirable parasites, and it assists in giving the moisture which the nest requires. The baths should never be allowed to remain all day in the aviaries, because if so the cocks will often bathe when they come off the nests in the afternoon, and this in the early part of the season means that they cannot properly dry themselves ere the shades of nigit with their chilling winds are upon them. Late bathing is apt to result in colds and roup.

\section{FIRST AID.}

There is just one nore point I would like to mention in connection with helping backward hatching youngsters. It is this: When a bird is a long time coming out after it has first chipped, some fanciers adopt the system of giving a little stimulant, a kind of "first aid." The difficulty which is experienced by so many young birds in getting froe of theit prison house is doubtless due to lack of vigour, therefore a little stimulant supplies them with "Dutch courage," and they break the bonds which hold them.

The stimulant used in such cases by the knowing ones is very weak brandy and water, the strength being about ten drops of water to three of brandy. Why brandy in preference to any other spirit? Because brandy is the juice of the grape. WVe know what brandy is, and, therefore, it is safe to use it. The way to adninister the brandy and water is to 
take a quill toothpick (quill toothpicks are wonderfully useful things to a Pigeon fancier), dip the broad end in the brandy and water, taking up about three or four drops of it, then touch the beak of the squab with the tip of the finger; it will generally open it slightly; as it does so, yot can place the end of the toothpick in the slight aperature, and the squab will suck the brandy and water down.

\section{TREATMEN'T OF DELICATE SQUABS.}

It sometimes happens that when young birds have emerged from the egg successfully, they are somewhat weak, and cannot take the nourishment their parents wish to give them. At other times the squabs are anxious to be fed, but their parents, for sonne reason or other, are not quite ready with the needful supply of soft food. From whichever of the two causes named the youngsters are not being fed it does not much matter; the fact is there, and unless food is given to them the wreakly babies will not be long for this world. In such cases, an egg should be beaten up and the youngsters fed with it. The best way to do this is to use a medicine-dropper, or a tube with which you fill your fountain-pen. Draw a small quantity of the egg up into the glass tube, then open the squab's mouth, insert the point of the tube, and gently squeeze the bulb. Only a few drops should be given at a time, because a young squab does not want its stomach overloaded the first two or three days of its existence in this world. "Little and often" is the golden rule in such cases. It is advisable, when administering soft food in this manner, to have an assistant, as it is rather difficult to hold the squab, and at the same time effectively handle the glass tube. If the assistant holds the squab in his hands, it leaves the operator with both hands free, so that with the left hand the beak of the youngster may be easily opened, and its hoad held so as to prevent its bobbing and nodding about, whilst the right hand manipulates the glass tube containing the beaten egg. A little assistance like this, the first two days of a squab's life, often preserves its existence, and enables it to continue in this world of trouble and care. 


\section{HON TO HAND FEED.}

Hand-feeding has also to be resorted to when the old birds feed one squab better than the other. Sometimes one of a pair of squabs is much nore vigorous than the other, and it obtains all, or nearly all, the sustenance which the old binds have to give in the way of Pigeon milk. At other times the parents seem not to care for one of their babies as they do the other, and systematically neglect it. There are occasions when the old birds have not the power of secretion sufficiently developed, and they fail to provide enough food for two healthy, vigorous squabs. When such is the case, sometimes one squab suffers, sometimes both. If both are equally strong, or equally weak, they both suffer together, but if one is stronger than the other-well, the weaker one goes to the wall, unless the owner steps in and gives assistance in the way of hand-feeding.

In any of such circumstances, the owner must supplement what the parents are doing, and the best way so to do is to moisten a small quantity of Spratt's Pigeon Food with boiling milk; mix it to the consistency of thick cream, then take a small glass syringe, plunge it into the mixture, pull out the plunger until the glass tube is full about one-third of the way up. Then take the squab, insert the muzzle of the syringe inside its beak, and slowly work the plunger down so that the creamy mass is ejected down the squab's throat. Should the syringe work at all stiffly, empty it, cleanse it with warm water, and recharge. Let every movement be one of gentleness. Do nothing harshly or roughly, of you may injure the beak or throat of a probable winner. A big, strong, healthy, growing squab that is neglected by its parents will take a great dcal of feeding in this manner, and its crop will not be filled all at once, ncither should you try so to do. The creamy mixture of Spratt's Pigeon Food and milk quickly thickens in the tube, therefore after each portion of food has been ejected from it the syringe should be cleansed. This is casily done by the aid of a basin of warm water, which should be at hand at such a time. As the tube 


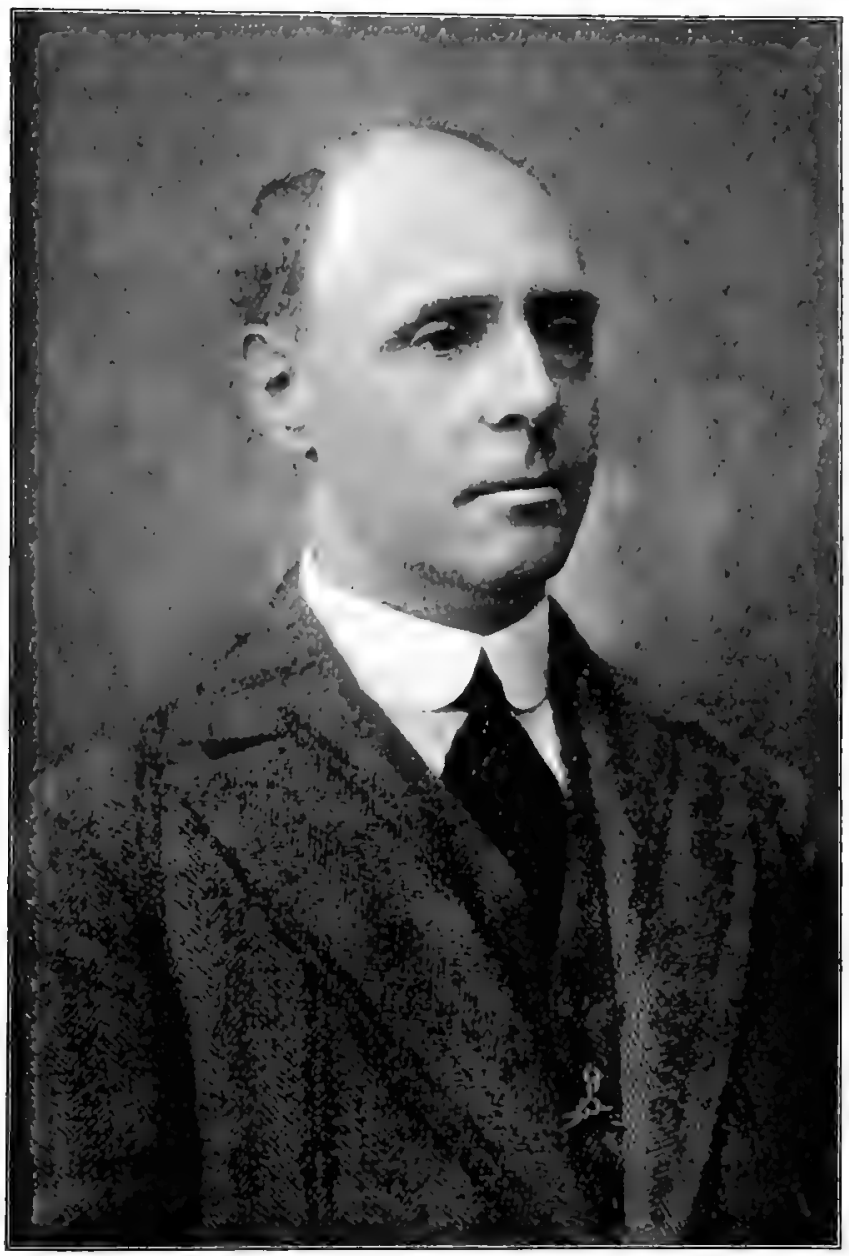

Mr. J. E. Watmough,

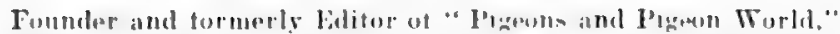
"Fur and Fouther" and other mon-piopers. Fonnder and

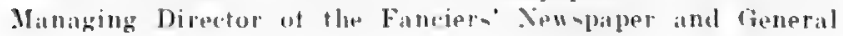
Printing and Publishing Co., Ltd. A life-long bramer and exhibitor of Horses, Dogs, Pigeons, Rabbits, etc. 

is relieved of food it should be charged with warm water, cleaned out, and then recharged with the creamy mixture.

\section{TROUBLESOME BUT USEFUL.}

All this may seem very bothersome, and the taking of a deal of trouble, but I can assure you that it does not take long; in fact, the cleansing of the tube really expedites matters, as you can re-charge and empty the tube much more quickly and more easily when you cleanse it each time. Further, if it is not cleansed in this manner it is apt to clog, and should it clog there is nothing more natural than for the operator to exert a little extra force on the plunger; he does so, it slips, with the result that the squab's beak is broken, its neck punctured, or its crop burst. Should it happen that either of these accidents occur it is wise to at once kill the injured youngster. It is usel€ss persevering with it after such an accident. Still, if ardinary care and gentleness are used such a contretemps will not happen.

\section{SOMETHING TO REMEMIBER.}

The chief thing to remember in all these operations is that a young squab is a very delicate little creature, and that the spark of life is very quickly extinguished if there is any rough usage. On the other hand, life is very tenacious, and Nature does not give way until great exhaustion takes place. It is really wonderful how some squabs hang on when they are neglected and only half fed by their parents.

When there are young birds about the owner should carefully examine every nest bowl first thing in the morning, at mid-day if possible, also at the time of the evening feed, and most certainly the last thing at night. If the daily vocation of a fancier is such that he cannot give this personal attention to his birds during the day, he should if at all possible depute the task to someone else, but taking care to make the first visit in the morning, and the last thing at night himself. 


\section{6t Pigeons and Ali About Theri.}

\section{A COMIION ACCIDENT.}

It sometimes happens that a young squab gets thrown out, or pulled out of the nest on to the floot of the loft itself. If the latter, there will be little chance of the owner doing anything for it, because it is a thousand to one against its being alive when found. It is very strange, but nevertheless perfectly true, that such quiet peaceful living animals as Pigeons are generally, and such good parents too, are at times most cruel. The sight of a poor helpless squab on the floor of the loft arouses in them some latent feeling of cannibalism, and they at once set to work and commit cold blooded nurder. The manner in which they do so is awfully rruel, as they simply peck and peck at the poor little squab until it is dead.

Such a catastrophe will seldom happen if thete is a good deep ledge of four or five inches in front of each nest box. In such cases, although a youngster may fall out, or be pulled out of the nest pan hy becoming entangled in its parent's plumage, it will get no further than the floor of the nest box. When found by the owner it may be to all appearance dead. There is an old proverb which says: "Things are not always what they scem," and over and over again have I proved its truth in Pigeon culture. When a youngster is thus found on the floor of the nest box, even though to all ontward appearance dead, stiff and cold, it should be taken into the house, and standing as near to the fire as possible, the owner should hold it in his hands, standing away from the fire every few minutes to breathe upon the bird whilst holding it closely between the palms of his two hands. That is, with both hands close together, and breathing heavily upon the squab from the small aperture between the two thumbs. In holding the bird near the fire care must be taken not to let the head be exposed to the fierce glare of the hat; let the bird lie in the hand upon its back. Persevere in this manner for some considerable time. I have known half an hour to elapse before any signs of life were observed. 
TROUBLE WELI, REPAID.

As soon as signs of life are seen the joy is great, and you say, "Well, it's worth all the trouble; I have saved a life." Should it so happen that you have not time to stay long with the bird in your efforts towards resuscitation it is a good plan to roll it in a piece of old flannel and place it in an old hat in the front of the fire, or if it is a closed stove, on the top of the stove; many a young Pigeon have I resurrected in this manner. The trouble often is great, but then great is the reward if you are successful. Even if you fail, you have the joy and satisfaction of knowing you did your best, but the odds against you were too great for your powers. It is far better to have sitriven to do something, and to have failed in the attempt, than not to have tried at all. In the one case there is always the comforting reflection, "Well, I failed, but I did my best" ; whilst in the other there is only the remorseful feeling, "I wish I had tried; I might have succeeded."

\section{EGG BINDING.}

I mentioned earlier in this chapter that though the long-standing of a hen in the nest pan is one of the signs of egg-binding, it does not necessarily follow that a hen so standing is egg-bound. When that standing is noticed in conjunction with other symptoms then egg-binding doubtless is present.

Egg-binding usually occurs with the first nests, and young hens are more prone to it than old ones; further, it generally occurs when the weather is extremely cold, and especially during the prevalence of East winds. This being so, those who have birds paired up must look carefully after them, as in such weather thens are apt to lose the uste of their limbs, or become egg-bound. When shutting up birds at night, when letting them out in the morning, and when feeding, a careful searching glance should pass over the whole stock. If a hen is found which has lost the use of her limbs, take her away from the aviary into the house, and place her in a basket somewhere near the kitchen fire, not too close, but just 
close enough for her to foel the gentle warmth of the fire. Give a couple of Dixons Revivers, and the chances are that in a few hours she will be all right. She should not, however, be returned to the breeding pen at once; let her rest for a few days amongst the spare hens; it will give her srstem time to recover itsclf.

\section{SHUTTING UF' THE NEST BOX.}

When the him is taken away, you must, of course, shut up the nest box, and put the cock bird cither anong yout spare cocks or else in a small pen by himse.f. If you leave him in the loft without a mate he will very soon discover that of the other cocks he will be able to say, "They all have a mate but me," and as a result he will determine to destroy the peace and happiness reigning in other families, by making love more or less to the mates of other cocks. This leads to fighting, to the breaking of eggs, the scalping of youngsters, the neglect of roungsters, and other evils equally uindesirable and to be avoided if possible.

In the case of agg-binding the remedial measures must be prompt to bo effective, hence the need for a watchful eye when in the Joft at this season of the year, especially amongst the young hens. As prevention is so nulch better than cure, strive to prevent cases of egg-binding by having your birds as fit as fiddles bufore pairing them.

This perfection of condition can be obtained by letting thom have plenty of exercise, an abundance of fresh air, fresh, clean drinking water every day, the best of food, and casy access to grit. This latter is nore important than many people think. The lime, salts, and iron in the best grits art most essential to the welfare of Pigeons, and are guite as essential as good food.

\section{SIMP'OOIS AND TREATMEN'T,}

How is the young enthusiast to tell a case of egg-binding from mere loss of limbs through cramp? An egg-boutnd hen is a sorry-looking creature, and innucdiately a hen is found standing in the nust-hox 
or pall, with her feathers wrong way up, her tail drooping, her eyes dim and dull, and her head hanging as though the muscles of het neck were broken, c.gg-binding should be suspecter. The hen must be caught and carcfully examined. If you are satisfied it is a case of egg-binding-and this you can easily tell by the inflamed appearance of the vent, and by fereling the egg near to the opening--you should at once set about relieving her. The first step in the process is to dip a large feather, or a fine camel-hair brush in sweet oil and insert it into the egg passage. Then hold the hen over a basin of boiling water, first stretching a picce of muslin over the top to prevent the hen's body coming in contact with the water and also to catch the egg should it be voided, as it sometimes may, whilst the steaming is being performed. Steam the hen for about a quarter of an hour or twenty minutes, and if the egg is not passed during this time, give her a couple of linseed oil capsules (those sent out by Mr. Richand IToods I can strongly recommend, because of the highly refined oil used in their manufacture), and place her in a basket neat the fire. Don't use an ordinary show basket, but a good-sized square marketing basket, or a round basket, such as is used for Fantails and Bantams. Such a basket allows the hen to move about, and stretch her body and limbs, and thus in most cases assist in bringing the egg away. If the egg has not been passed in a couple of hours repeat the steaming. A word of cantion is necessary as to this operation. Don't hold the hen too close to the top of the basin if your water is boiling, or you will scald her by the great heat of the steam.

\section{PROMPTITUDE NEEDED,}

In cases of egg-binding, relief must be afforded promptly as soon as ever the discovery is made that the hen is holding her cgs. Delay may mean the loss of the hen's life. The exhaustion in egg-binding is great, and hens quickly become prostrate. It must ever be remembered that as warmth is a great factor in effecting a cure, the hen must be kept near the fire 
until she has quite recovered. If after the treatment before given, the egg does not come awav, then hot fomentations must be tried. The ordinary decoction of chamomile flowers is one of the biest for the purpose-a handful of the flowers to a pint of boiling water. After each fomentation dry the feathers carefully, and make the little patient as comfortable as possible ere returning her to the basket. The bottom of the basket should be covered with some very soft, well rubbed hay or a piece of old flannel. In very stubborn cases, and as a last resort, ergot is a remedy which may be tried. Give it in three drop doses three times a day, till the poor little sufferer is relieved.

\section{TREATMENT IN EXTREME CASES.}

Prolonged cases of egg-binding usually result in the setting up of inflammation of the egg passage. It is, therefore, wise in such cases to give one or two drops of laudanum in five drops of sweet or linseed oil every three hours. This will ease the pain and give temporary relief. It sometimes happen's that the egg becomes broken. If this does come about, then great care must be used in getting away the whole of the shell, or bad inflammation will be set up. Should this happen, the ergot treatment should be resorted to, as this will have caused the egg passage to dilaite and allow of the introduction of a small pair of tweezers, with which to bring the shell away. Ere using the tweezers they should be sterilised by dipping in boiling water, wiped dry with a piece of medicated lint or wool, and then dippod in carbolised oil. Some may think this unnecessary. It may be, but nemember the whole of the organ's are in a highlyinflamed state, and the neglect to take ordinary antiseptic precautions may result in the loss of a valuable hen.

\section{WEARISOME AND IRRITATING.}

Bad cases of egg-binding are most wearisome and irritating, but one must not get anxious or excited. It is, I know, very easy to preach, but much harder to practise, and when one sees the best bird in the 
stud gasping for breath, and looking as though every moment will be her last, it is not easy to be calm, cool, and collected; and yet one must be. I don't know if it is animal magnetism or what it is, but I do know that if you are treating sick animals, and they find you steady and cool, they seem to be inspired with something of the same feeling, and it greatly aids their recovery.

A hen which has been egg-brand should not be returned to the breeding loft for a week or ten days, and in a severe case a fortnight or even three weeks is not too long to give her to recuperate; the more valuable the hen, the longer she should have to recover her strength. If ample time is not given for recovery, then you may expect another attack, or your hen may lay shell-less eggs, or worse still, may become ruptured, and thus useless for either the breeding or show pen.

\section{DIFFICULTIES GREAT.}

I am thinking that some of my readers will be coming to the conclusion that the difficulties which beset the path of the young beginner are so numerous that it is almost an impossibility for them to cope with such, and are feeling somewhat dismayed. I hope, however, their numbers are few, because, although I have mentioned many of the difficulties which bestrew the path of the young aspiran't for fame, I have also etndeavoured to point out in the fullest manner possible how such difficulties may be attacked and overcome; and as knowledge is power, the knowledge that such difficulties have to be met and overcome is in itself a source of power; whilst the further knowledge of how to effectively cope with them, how and when they arise, enables the new beginner to fieel (that is, if he is possessed of an ordinary amount of pluck) that come what may he has the power to grapple sticcessfully with the disadvantages associated with Pigeon culture; and knowing he has this power will press forward to dare and conquer the adverse moods of Mother Nature. 
Givun ordinary natural ability I maintain that what one fancier has donc, another may do, even if he does not make adrance on what has been done before. Those young fanciers who read my book should remember that the norices of thirty years ago had 110 such assistance as those of to-day receive. Elcmentary, educative articles were seldom seen in those days, whilst cheap handbooks dealing with Pigeon life were also unknown. Thirty vears ago fanciers had to grope and grope, dig and delve, and search and seck in the blindness and blackness of ignorance; yet they conquered. If they could do it, surely the novices of to-day ought to prove victorious in tenfold degree, because of all the aids to success which they have at command. Indomitable pluck and energy will carry one far, and there is no height in the Pigeon Fancy which nay not be scaled by the young aspirant to honours if he is only determined to make full use of the aids to success which are within his grasp.

\section{PREPARATION FOR THE SECONI NEST.}

But to get back to our Pigeons. When the roung bircls are from a fortnight to three weeks old their parents will manifest a desire to go to mest again. This is often a troubled and anxious time to the new beginner. He sees the old birds so intent upon bringing anthether pair of squabs into the world, and they neglect those to which they have already given life. This is a time whon the owner can do much. With some birds little has to be done, because 110 matter how anxious they may be to go to nest again they never cease to look after the roungsters they have already brought into the world. The owner should, however, kecp a watchful eye orer any young squabs which are in the nests at such time. If they are very choice birds, no ham will be donc if each morning and night he gives one or two of Troods' Nutrisules, or Tocher's Invigorators, to the youngsters, whilst if they are being neglected, he will be doing a great deal of good by possibly saring the lives of his squabs; in any case, he will, by giving 


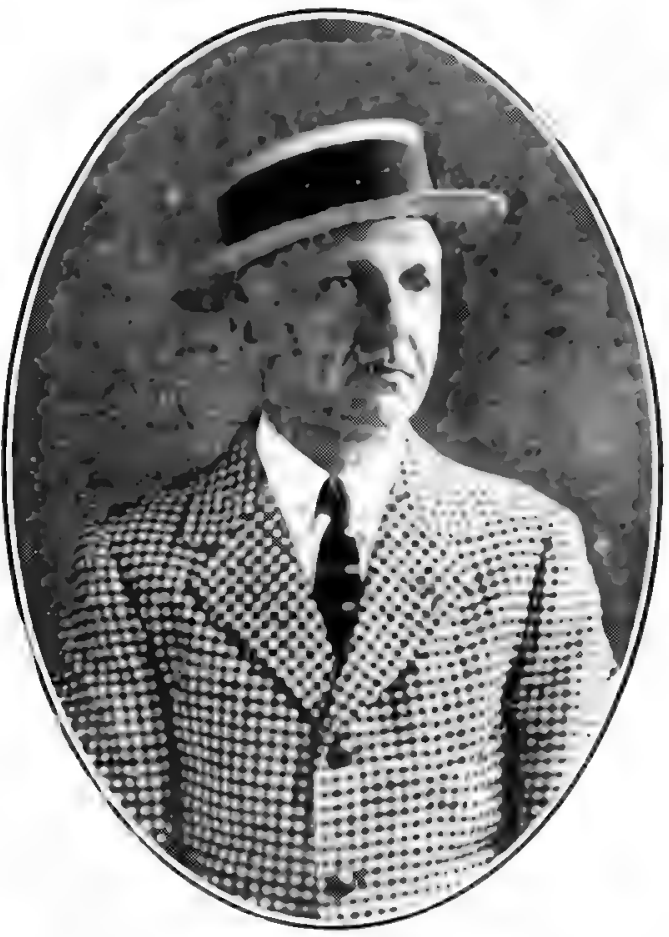

Mr. Robert E. Pauwels, of Brabant, Belgium.

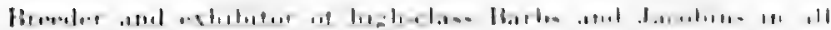
colours, but specialises in the former. In addition to having accounted for thousands of prizes at the best Continental

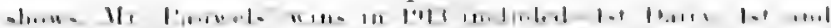

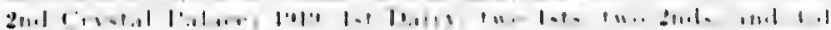
Manchester. The stud is managed by Mr, R. S. Powell, wellknown to those who visit our classic shows. 

them these capsules, enable them to assimilate more fully whal food the old birds have to give them, and also enable them to feather quickly.

USEFUL PRECAUTIONS.

When the old birds are going to nest again they often forget to cover the young squabs at night, and this is when the harm is done. Young squabs that are kept warm at nigh', evon though they may not be over well fed, will thrive and do better than those which are better fed but having nothing to keep them warm through the long cold nights of the early part of the season. When a fancier finds that the old birds are again driving to nest, he should take careful notice of his stock as soon as night closes in, and if those hens intent on preparing for their second family neglect to cover their early babes, artificial covering should be provided in the shape of a piece of old flannel or blanket being thrown over the nest pan each night.

\section{CARELESS PARENTS.}

Should the parents be on further matrimonial projects so intent that they neglect to feed their first babes the owner will have to hand-feed them. When this is needed, a quantity of mixed corn, maple peas, tares, wheat, dari, and some small Indian corn should be soaked in water for 24 hours, and given to the squabs. There are two methods of hand-feeding. One is by taking a handful of the soaked corn and forcing it into the throats of the squabs by the manipulation of the forefinger and thumb-and some fanciers are very clever in so filling a youngster's crop. The other method is to fill the mouth with the soaked corn. Place the beak of the youngster between the lips, and by the action of the tongue eject the corn into the squab's crop. I have known fanciers who could thus feed a dozen youngsters as quickly and effectively as their own parents would feed them.

\section{A NEEDFUL CAUTION.}

In connection with this hand-feeding with soaked corn, I must give a special word of waming. After the water in which it has been soaking has been 


\section{Pigens and Ali About Then.}

strained off the corn, boiling water should be poured over it, and allowed to stand for a few moments so as to warn the corn right through. If this is done the food so given is much more easily digested by the young squabs. They feel more comfortable than if a lot of cold water-logged foor is rammed into their crops. Digestion being rendered more easy is also more thorough. There is not the sevore tax on the digestive organs, the food is more easily assimilated, its nutriment more quickly and thoroughly extracted, and there is less possibility of cliarrhea and other intestinal troubles being set up.

As a rule, the neglect of the youngsters only lasts for a few days, and then having got over the fever and excitement of thinking of the second nest, the old birds take up their parental duties again in the most exemplary manner; but it is during those few days thai the future of many a would-be champion is not only marred, but completely spoiled. Hence the great importance of the birds being well watched at this time and artificial feeding being resorted to. No breeder of high-class birds should enter upon the breeding season's campaign without a supply of Wood's Nutrisules or Tocher's Invigorators. There are times in the life of a young squab when one of these assistants to the upbringing of young Pigeons is worth its weight in gold. To be forewarned is to be forearmed.

\section{FROM SQUABDOM TO SQUEATERDOM.}

When the hen has laid her second batch of eggs and gone to nest, the cock will do the major portion of the work entailed in looking after the first family. He it is who will see that they get their breakfast in the morning, as the hen will then be on the nest, and lie it is who will give them their supper at night; and these are the two most inmortant meals in the day for young growing Pigeons just emerging from squahdom to squeakerdom. I may say here that whi'st young Pigeons are in the nest-pan and have not much except down to cover them, they are known as silnabs, but when they are feathered and leave the nust-box 
and begin to take interest in the great world outside, they are styled squeakers. How the two names originated I an unable to say, but the latter appellation is indeed a good one, for the young Pigeon from three to eight or ten weeks is a most effective squeaker. He not only squeaks when he wants food, but he squeaks if he is handled, and he also squeaks if other Pigeons interfere with him.

\section{EARLY RISING NEEDFUL.}

During the breeding season the would-be successful fancier must be up betimes in the morning. Firsts, specials, and challenge cups are not for the sluggard. If young Pigeons are to make prize-winners in after life they must be kept growing, and the best way to keep them growing is to let them have plenty of good food, early and late. Pigeons, like all other winged fowl of the air, are early risers, and they begin to move about even before the sun is above the horizon ; and for young Pigcons to have to run about for a long time in the cold air of the early morning with nothing in their crops is not conducive to growth of body, muscle, or feather. As it is most important that these should be developed in the best manner possible, it will at once be seen how necessary it is that the young birds should go to bed with their crops full, and have them replenished as early as possible in the morning, because during the long watches of the night the food given at eventicle will have been digested, and all its warmth-giving and growth-giving properties assinilated. Warmth is a great factor in the growth of a young Pigeon's body, and also in its feathering.

\section{VALUE OF AN EARLY FEED.}

Now we are all of us fully aware that we ourselves feel the raw, nippy air of the early Spring mornings far more before breakfast than we do after, and if we do-how much more must the naked squabs and half-naked squeakers! With a full stomach they not only grow and make feather, but their bodies ate strengthened and built up so that they are able to 
withstand the microbes of any disease which may be stalking about. It must ever be remembered that birds which are only half-fed, or improperly fed, are ever more prone to disease than those which, by reason of good feeding, are strong, lusty, and of full habit. The ordinary rules of life hold good all through the animal world, and what is good for man is also good for beast.

Therefore, I say to all my young friends: Never neglect to feed your Pigeons early in the morning, especially during the breeding season. It may not be over pleasant to turn out on the frosty mornings of the early part of the season, but it is absolutely needful if the birds are to do well; and further, the benefit of the early rising will not all be on the side of the Pigeons, although that should be enough to bring it about. Early rising brings its own reward in increased health and vigour to those who practise it.

\section{THE WEANING TIME.}

By the time the second pair of eggs are due to hatch the first pair of babes will be able to do for themselves, and they should be removed from the house in which they have thus far lived. If it is not possible to remove them to another house-well, then, they must perforce remain; but when and wherever possible young squeakers should be removed from their parents abont two or three days before the next family is due. The reasons why this should be done are several. In the first place they will, if left, interfere considerably with the fresh-comers, and with the comfort of the parents, they will be continually clamouring to be fed, and thus will get a share of the food which should go to nourish their younger brothers and sisters. They will also be climbing about in the nest-pan, and possibly trample the new babes to death; or if they don't do it themselves will cause the parents to do so. Another point in this direction is also worthy of consideration. Should it so happen that the parents are so enamoured of their new family, they may not make any attempt to feed those whom they know should now be starting life 
on their own, and the consequence is that the squeakers, having been used to receive their meals from their parents, stand about waiting for the food which cometh not, and thus their growth and development is checked. This does not happen when they are taken away and placed in another loft. They are out of sight, and out of mind of their parents, and self-preservation being the first law of Nature they soon set about feeding themselves. It sometimes happens that when babes number two make their appearance the parents not only refuse to fered babes number one, but will so resent their presence that they set about them, pecking them with their beaks and hitting them with their wings, and in this manner do them serious injury. From this it will be seen that for the sake of the parents, for the sake of the early family, and for the sake of the younger babes, it is wise and prudent to have a nursery house to which all young birds may be removed as succeeding nests come round.

\section{A TIME FOR CARE AND CAUTION.}

The weaning time is an important period in the lives of our young squeakers, and under the very best of conditions they not only do not make headway for a few days, but they go backwards, and lose ground somewhat. 'This, however, may be minimised to some considerable extent by their owner constituting himself foster parent for a few days if necessary. For a few days, sometimes, the novelty of their new phase of life seems to prevent the squeakers from feeding as they should do. Shot1d this happen, their owner must resort to hand-feeding in the manner I described in a previous chapter.

This, too, is the time when those splendid aids to Pigeon culture, Woods' Nutrisules, are of the greatest benefit. At this time more than any other are they of service to the rearer of high-class squeakers, and many a life will they save if given two or three times a day. Many and many a future challenge cup winner has owed its life to them, and the fact that they are used by many of our leading fanciers in all varieties 
puts the hall-mark upon them. If they are founcl to be of service by men who are well versed in the management of Pigeons, how much more valuable must they be to the young annatenr who is not up to all the little dodges which experience teaches?

\section{ADTANTAGES OF TO-DAY .}

This is one of the things in which the amateur of to-clay has an advantage over fanciers of twenty or thirty years back. In those days there were none such. Good food even was difficult to obtain, but now we have corn-chandlers all over the kingdom taking far more interest in Pigeon corn than they used to do, and some eren making it a special line of threir business. This being so, Pigeon-keeping is a much nore pleasant and profitable hobby than it used to be in the days of yore. Happy they who are fanciers in the twentieth century.

The treatment which I have described for the first pair applies with equal force to the second and third pairs, and beyond this it is not wise to go. Three pairs of ronng are quite enough for any pair of Pigeions to bring up in a season. The reasons why are various. In the first place late-bred youngsters never do much good. They are born too late to ever have any chance in the show pen, and are too young to commence breeding with at the beginning of the following season. It should be an nuwritten rule in the management of every Pigeon aviary never to hatch out any eggs laid after the cnd of June ; some of our most successfiil fanciers are even more stringent still against late-bred birds, and they never allow their birds to incubate any eggs laid aftcr the first or second week in June.

\section{LATE BREEDING TO BE ATOIDED.}

Late-hatched birds are, of necessity, late in moulting, and late-moulting bircls are slow-moulting birds, which means that they are casting their coats during the cold, damp days of November and Decemler, at which time they need all the sustenance they derive from their food to keep the colkl out, and give support 


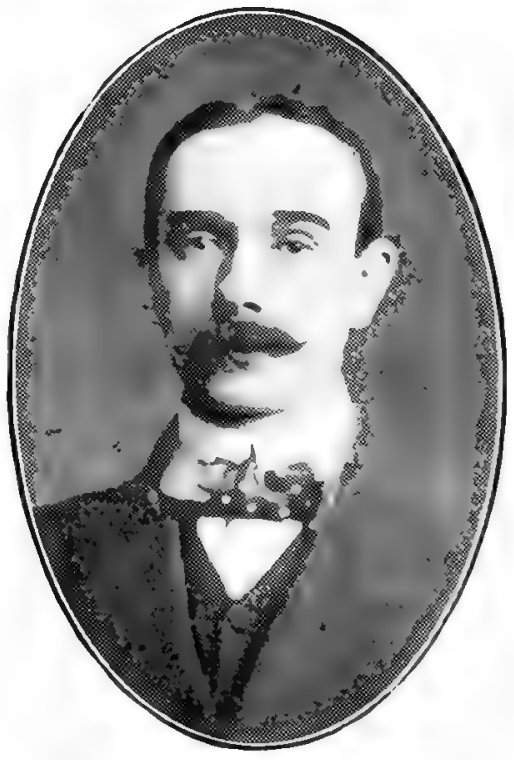

Mr. R. H. Bellamy.

A successtul breeder and exhibitor of Long-faced Beard 'Tumblers, winning challenge bowls, cups, and specials,

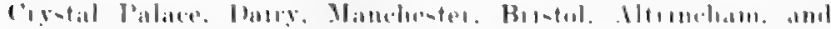
all the club shows. Won 1st Altrincham seven years in succession. Has produced more winning reds and yellows during the past fifteen years than any other breeder. 

to their bodies. Thus, if they are moulting at such time, there is a double strain on their systems, and the consequence is that neither do their coats grow properly, nor are their constitutions kept in full force and vigour. Bad as this is for the young stock, it is infinitely worse for the old birds. The strain of rearing four or five nests of youngsters is great, and when they have done so it stands to reason their supply of nervous energy and constitutional vigour has been severely taxed, and must of necessity be at a low ebb. Thus, when the moult commences, which it daes before they have finished tending their last nest of babes, they have not the requisite strength to go through it in a healthy normal manner. As a consequence they become ready prey, not only to colds and chills, but to many other ailment's to which Pigeon flesh is heir, and which are generally stalking about through the loft seeking something to devour. Many and many a good old hen has been lost owing to her owner's greed in seeking to take too many youngsters from her.

\section{HOW NO'T TO DO IT.}

As an illustration of the harm that is done by late breeding, I will give a case which came under my notice some time since. A fancier known to me was the possessor of a wonderfully good bird, one of the best of its variety living. He had never owned such a good specimen before, and as the breeding season progressed the owner found that the pride of his loft was just as good a stock bird as he was a show bird. The youngsters he produced were magnificent specimens of their kind, and well fitted to uphold the honour of the loft in the show pen. This being so, my friend bred on and on until the had taken no less than six niests from his champion. Breeding both early and late, he burned the candle at both ends, with the result that the gem of his collection never moulted properly, was in a sort of half-moulted, ragged state all through the winter, and thus was never fit to show. The next year's breeding season came round, and the bird was paired up, with the restilt that the 
first nest contained unfertile eggs. My friend is now as wise as the legendary Raven, and with him it is a case of "Nevermore." My warnings were unheeded. "The bitd was a big, strong, lusty specimen, and he would moult all right," was the owner's answer to my remonstrances. But he found that the breeding had taken too much out of his constitution, and he did not monlt "all right." He has lcarnt wisdom by expcrience, and will not again repeat his foolishness and breed late.

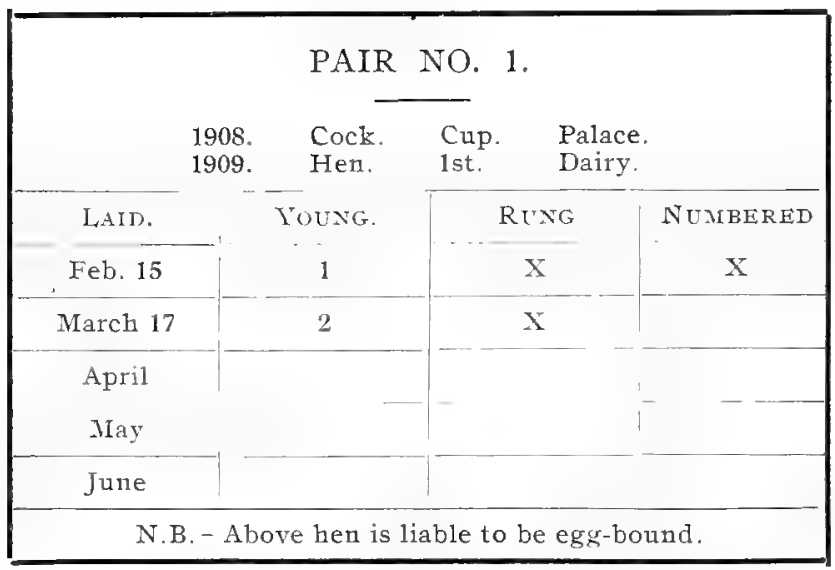
A useful Reference Card, which may be fastened to outside of each nest box for dally memoranda.

\section{LOOKING AHEAD.}

Fanciers must ever remember that there is the future to think of as well as the present, and that if birds are to be fit, strong, lusty, and hearty at the end of February, when the pairing-up time comes, they must not be bred with beyond the month of July. Then young birds which are hatched in tugust and September are not sufficiently matured by the next breeding season to beconce the parents of strong, healthy youngsters. They may go to nest, they nuay 
have fertile eggs, and they may rear their young, but there is never the virility, vigour, and vivacity about their stock that there is about the stock of bircls which are not paired up until they are fully matured. If birds are hatched in July they are only seven months old when paired up the following February, and this strely is young chough in all conscience! To mate up birds under this age is to court disaster instead of success.

To get back, hownever, to our newly-weaned babies. They must be carefully watched for some time, and if they are at all valuable it will not be a case of love's labour last if they are given a couple of Dixon's Cod Liver Oil and Quinine Capsules each night for a month after they are taken away from their parents.

The staple food for newly-weaned Pigeons should be the same as that which is given to the breeding birds, and which should be equal parts of maple peas, tares, wheat, and dari, with just a sprinkling of small maize; whilst each night after ther have had their feed of corn they should be given a dish of Spratt's Pigeon Food. This is a most admitable preparation, being strong in protein and carbo-hydrates. and is of great assistance in buildling up strong, robust constitutions in the young stock, assisting them in the putting on of muscle and the development of feather.

\section{CLEARING OU'T THE WASTERS.}

When the second nest of youngsters have reached the weaning stage, they should be treated in exactly the same way as that recommended for the first, and by this time, in many varieties the early youngsters will be sufficiently developed for their owners to know if they are likely to be of any use for either show or stock. A large proportion of the birds bred mar be only fit for killing, and the earlier they are killed the less will be the corn-bill; and the better birds, having more room given them, will develop more frecly and become finer and stronget birds than if hercled up and overcrowded with a lot of second-raters. Further, from six wecks to two 
months, young Pigeons make very nice eatingeither roasted and served with bread sauce and crumbs, after the manner of partridge or pheasant, or under a nice brown pie-crust. After the age of two months their flesh becomes hard and stringy, and is not so succulent or appetising. never hesitate to kill your wasters early.

"But how am I to know which are my wasters?" I hear some of my young friends say. Quite true; you will not know what to kill and what to leave to grow and mature. Therefore, my advice to you is to seek out some other fancier in your immediate neighbourhood who has some experience, and ask him to go through your stock with you. Under his guidance and counsel you will soon learn which to keep and which to reject. If it should happen that you are so situated that you cannot find anyone to advise you, well then, you must trust to your own knowledge and instinct, or else let all grow up together, the good and the bad. If, however, you have any idea at all of the variety you are keeping you will be able to pick out those that are real wasters. For instance, in Dragoons, it would be useless keeping a very down-faced, spindley-beaked youngster; in Homers or Tumblers, birds with coarse light ceres are useless, except for cooking; Jacobins with split hoods and very thin broken chains; Fantails with wry tails, uneven gappy tails, no action, and long legs; Magpies and Tumblers badly mismarked, or wrong in head structure; Turbits and Owls with narrow skulls, fine beaks, and pinched faces are all amongst those that should be killed. They are only cumberers of the ground, eating good food which should be consumed by better birds, and depriving those better birds of the greater amount of fresh air and exercise-space which they should have.

\section{CHANGING MATES.}

By the time the second round is a fortnight old, the breeder will have seen enough to be able to form some idea of the results of the different experimental matings which have been made. In some cases they 
will have been all that could be desired; in others, quite the reverse. In the former, of course, it will be wise to leave alone, but in the latter something must be done to see if the ideal which was being aimed for cannot yet be secured ere the season has run its course.

As an instance of what I mean I will give a case in point. A breeder of red and yellow self Tumblers, anxious to improve the head properties of his strain, has introduced a cock from another strain, quite equal to his own in shape, colour and style, but decidedly better in head. He has mated this bird to a most excellent hen, the best in his stud, but the result has not been what he expected. Certain it is, head and colour have both been improved by the cross, but with this improvement has come a failing hitherto unknown in the stud-white feathers in the tails of the young. This may have come from the cock, or from the hen. One cannot be sure which. It is most probably a throwing back to some remote ancestor on one side or the other. The white blood has been there all these years, but it has lain latent. The infusion of alien blood has awakened it into life, and it has shown itself in the tails of the young. These youngsters, of course, are useless as exhibition birds. No matter how they may develop, they can only be used as stock birds, and very carefully even at that. That, however, concerns the future; the present is what we have to deal with.

\section{HOW TO DO IT.}

Unless the season is to be wasted, so far as these two birds are concerned, they must be dismatched, and fresh mates found for each of them. In doing this they must, as soon as separated, be kept for about a week or ten days, not only out of sight and sound of each other, but also of all other birds, if this is possible. If it is not, then they must certainly be kept out of sight and sound of each other, or they will, although unable to see each other, yet call to one another, and refuse to be comforted by the advances of the fresh mate, which will have to be introduced 
to thenl. Mrhen a dismatching of this character takes place, two pairs usually are involved, because of the necessity of finding fresh mates, unless it be in a large stud whore a number of both cocks and hens are held in reserve.

Immediately the birds are taken from the breeding loft their nest-box should be fastened up. This will prevent other birds from starting on a roving career, and save a lot of squabbling and fighting when the birds which have been re-matched are brought back into the loft. In bringing them back it is most essential that each cock should be placed in the same nesting box with his new mate as he occupied with his first love. The reason why, does some young reader wish to know? Because the cock bird is the one which selects the home for his bride, and having inhabited it with his first love will certainly endeavour to introduce his second love to it, should his ownet be so foolish as to place him elsewhere. Let the cock lhare his original home; it will do much to make him forget his first love, and enconrage him to settle down with the second bride of his master's choosing.

\section{SIMIPLE YET IMPORTANT MATTERS.}

I have been progressing somewhat too fast. When the birds that have not fulfilled expectations are dismatched they must, as I have said, have a week or ten days solitary confinement, or else be placed with other surplus cocks and hens. If this latter course is followed it will be beneficial, becanse the birds will be getting regular excrcise and baths, which they will not get if the resources of the stud are such that they have to be penned up. Having been given timu to forget their first loves they will pair uip the more quickly when introduced to their new mates. These are simple little matters, but upon their neglect or carrying out great issues may hang, and it is in these little things that the romng fanciers net adrice and guidance. Wisdom comes with experience, and the old hands are apt to smile at times at simple and clementary teaching. They may smile. They have learnt wisdom, some of them at great cost; because 


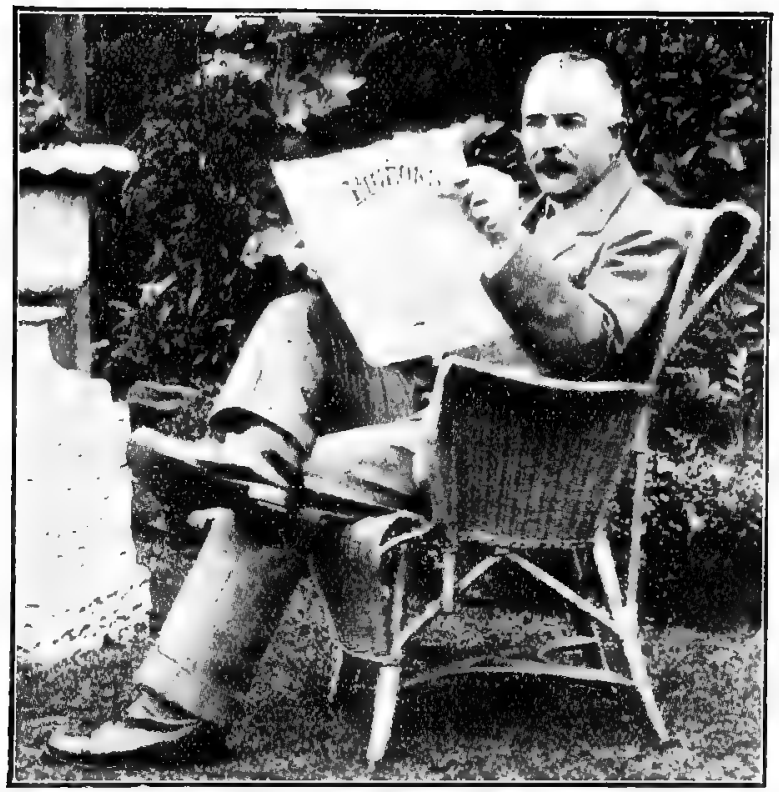

\section{Mr. James Staite Murray.}

A well-known believer in the potency of the cock; a writer on the subject of "The Pond of Little Fishes" or the "Atoms of Life" ! A member of the Middlesex Columbarian Society. the Long-faced Self Club, the London Long taced Tumbler Club, the Scottish Long-faced Tumbler Club, and the South Jundon Columbarian Society. Won the Red Selt Bowl in 1917. 

in years gone by the young budding aspirant for fame was not thought about as he is to-day, and not being thought about was not catered for. Only those whose position brings them into close touch with the novices know how very disconcerting and disheartening to them are the little details of management which need care and thought, and the questions which are addressed to myself and others who are looked upon in some degree as guides in Pigeon lore, are almost pathetic in their intense eagerness. They often cause me to think of my salad days, and of the stupid things I used to do for want of knowing better.

\section{THE RE-INTRODUCTION TO THE LOFT.}

When re-matched birds are returned to the loft they must be carefully watched for a few days, just to see that they settle down all right. It often happens that the other birds in the loft want to have a say in the domestic arrangements of the newly-married couples. Sometimes it arises from curiosity, at others from downright cussedness, but be the cause what it may, the interference must be prevented. If there is any interference it will be wise to shut the newlymarried ones up in their nesting-box for a few days, say until such time as the hen has laid and commenced incubation. To carry this out effectually and secure either the birds or their home from molestation by interfering or inquisitive neighbours, the newlymarried ones should be let out to feed, and as soon as they are out their nesting box should be shut up to keep out intruders. After they have fed and bathed the box may be opened, and the birds allowed to go back of their own accord. If it shonld happen that they are at all dilatory, then they must be caught and returned to the box, and the entrance barred to all who may seek to call upon them. The reason for all these precautions is that there is no time to lose, and that if the re-matched birds are interfered with it may result in clear eggs, soft-shelled eggs, or eggs being smashed as soon as laid; should such thappen then the re-matching will have been labour in vain. 
Many will say they can understand that eggs may be broken by the interference of outsiders, but why should that interference cause shell-less eggs? The shell-less eggs will be caused by the hens becoming excited and passing their eggs before they have become properly shelled. Any outside excitement at such a time is bad for both cocks and hens, and will generally tend to evil results.

\section{A TIME OF REST.}

Between the end of the breeding season and the commencement of the moult birds should be giren a time of rest. It is only common humanity and common sense, too, to allow them time to recuperate from the effects of the breeding season ere they are plunged full into the moulting period. Therefore I advocate an carly cessation of breeding. Birds that are bred heavily are more than likely to have a very bad time during the moult, owing to their systems having become exhausted by the work which they have undergone. Clear out all breeding utensils extra carly, and give the houses a thorough turn-out. Those who love the whitewash brush can use it now to their heart's content without fear of much eril in the way of colds resulting from the dampness of the boards and walls, whilst in addition to sweetening the lofts, the lime on the walls and ceilings will also tend to keen them cool in the excessively hot weather.

\section{CLEIRING THE SISTEM.}

Birds which have been brecding should, on being separated, have what is known anongst stock breeders as a "clearing ont." 'This, howerer, nust be done carefully and judiciously. An expert in a Fancy journal recommended some young fancier to gire his birds a solution of Epsom Salts of a strength which, to me, was appalling. The strength adrised was onc onnce of Epsom Salts to eight of water. My cxperience teaches me that the effects of Epson Salts on Piseons are very active, and that half an ounce of Fipsom Salts is sufficient to medicate a gallon of water. 
It nust be remembered that in the course of a summer's day Pigcons drink a large cuantity of water, and that if it is made too salty very serious injury is likely to accrue, even if death cloes not follow. I have known more than one fancier who has suffered from giving his birds a solution of Epsom Salts of too concentrated a character. If, when the brecding pens are broken up, the birds are given Epson Salts cach day for a week, in the proportion of half an ounce of salts to each gallon of water, it will cleanse their systems of all morbid humours, and render their biloorl clean and cool ready for the moult. I need not say more here as to the moult and the treatment of birds therein. 


\section{CHAPTER V. \\ EMBRYOLOGY.}

During the breeding season many fanciers are troubled with bad hatchings, and they are often unable to account for it. In some cases it may be the result of breeding with birds which are too old, too young, or, which owing to some weakness, either of the generative organs or some other part of the body are not fit and proper subjects to be engaged in the propagation of their species.

I heard rather an interesting argument on this point some time ago at a gathering of fanciers, and various were the reasons assigned for the state of things prevailing. Each member of the party had some pet theory of his own to propound as to the why and wherefore of it, yet none agreed with the other. One argument adduced was that in these cases of fertile eggs not hatchino, the hen, and the hen alone, was to blame, because once a cock had fertilised an egg it was fertilised, and its after development depended entirely upon the hen. If a hen was strong and healthy the young Pigeon had nothing to do but mature in the same manner as a seed grows and develops in the ground. At the time the argument seemed to me very convincing, but afterwards came the thought that there was bad seed and bad ground, and unless a gardener puts good seed into good ground he cannot produce a prolific crop.

\section{PERFECT CONDITION NEEDFUL.}

Does not the same hold good in embryology? Surely when one thinks the matter ont carefully it is absolutely necessary that both parents should be as fit as fit can be. An unhealthy or immature cock cannot fertilise the egos so effectively as one which is in full strength and vigour. Poor seed cannot produce a prolific 
crop, no matter how good the ground. Again, be the cock a strong, vigorous bird, in the very zenith of his power as a reproducer of his kind, how is it possible for him alone to ensure strong, healthy progeny? Careful thought has led me to the conclusion that the cock must be equally fit with his mate if we are to get the best results.

Embryology is a science which has occupied the attention of some of the greatest scientists in the world, and for ages learned professors and doctors have been studying it. Yet with all their skill, all their carefully balanced and delicate instruments, and all their devotion, they tell us that the science is even yet in its infancy. This is the conclusion of men who have made it a lifelong study for the sake of benefitting the human race. If these great and learned authorities are still so much in the dark, and openly acknowledge their lack of knowledge, is it to be wondered at that ordinary fanciers know so little about what to them is one of the most important subjects with which they have to deal?

\section{WHY FANCIERS ARE IN THE DARK.}

At the first glance it seems ridiculous that so little is really known by fanciers concerning the mysteries of embryology, yet second thoughts quickly give us a reason why 'tis so. As fanciers we are most earnest in our endeavour to produce, year by year, birds which shall excel in structural, feather, and colour properties the birds of the season immediately preceding. Onward and upward is the motto of the aspiring fancier, and his whole thought is concentrated on reaching the very apex of perfection as shown forth in the standards governing the variety he is interested in producing in a state of faultless beauty So enamoured is he of his love of the beautiful, the ideal which he has set before him, that he does not stop to consider and think out the weighty and mighty problems of Nature which assist him in climbing the heights which lie before him. The development of the embryo is hidden from his eyes by the shell in which it is contained, and so valuable are the contents of that shell, that he dare not, he cannot, investigate the processes by which Nature assists him in 
reacling his icleal. Further, did he set himself to study those hidden workings of Nature, he would have no time left in which to work and produce those marvenous sirecimens of the breeders' art with which he hopes to capture first, siecial and culy at the great event of the year. Thus it is that the man who produces year by year the most wronderful and beautiful specimens of the Columbothile race $1 \mathrm{~s}$ absolutey in the clark as to the why and the wherefore of the mysterious methods by which his results are achieved. Were it possible for a fancier to study, in a careful and painstaking manner, the science of embryology, sicle by side with the work of producing his cul wimners, we should know far more than we do now as to how Nature works from the time of the ego heing impregnated till the squab leaves the shell.

\section{HOW TO ATOID BAD HATCHING.}

One way to avoid the bad hatching of which I spoke is to breed only from birds which are thorourhly fit in every particular. It is a very common practice with fanciers to vair $u_{1}$, an old cock with a young hen, and a young cock with an old hen. The idea itself is a good one; the extra vigour of the youthful member of the lair is intended to counteract and counterbalance the impaired vitality of the older member. So far so good, hut it should be remembered that a young cock is much more forward than an old hen, and his very ardour and vivacity may cause him to so stimulate and excite his mate that she really comes into a breeding state earlier than she would have done had sle been left to follow lier own inclinations and the dictates of Nature. We all know we cannot force Nature's hand without her getting her own back with interest. She will be compensated for every ontrage we perpetrate against her laws, and compensatel in a manner which ofttimes upsets and frustrates all the carefully laid plans of a scason's breeding.

\section{THE LESSON TO BE LEARNED.}

What is the great lesson for us here? Why, that in all our hreeding arrangements we should suek to study Nature's methoils as closely as possible, and not 


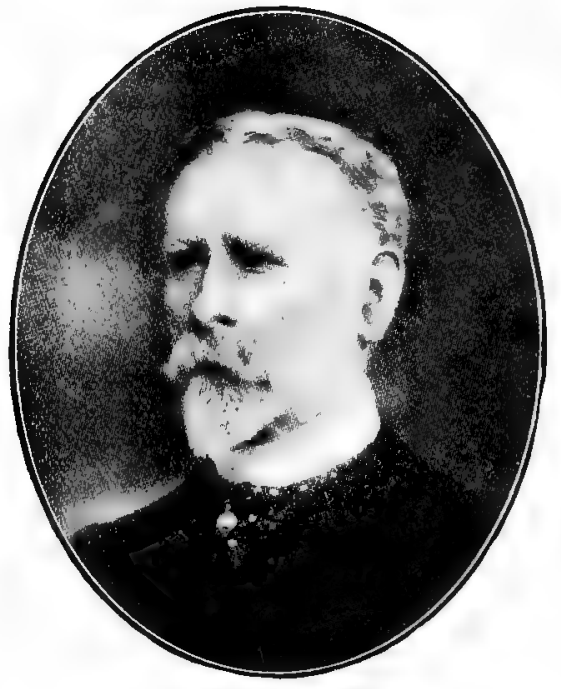

Capt. St. John Hornby.

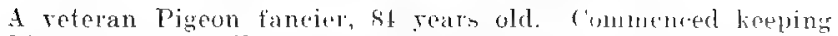
Pigeons 18kis; still lieeping Pigeons 1920. First P'resident of the P'inmy Pouter Club. 

work in antagonism to ler teachings more than we can possibly liclp. As an instance, we will take the case of a fancier with a valuable old hen. A bird of marvellous structural properties, or, maybe, excclling in colour and feather-a bird which, for some scasons, has held her position as the ackilowledged champion of her variety; she has bred for sereral seasons and produced good stock, but now the rarental cares of past years, and the effects of spending many days and nights in the show baskets and pens are telling upon her constitution, and although still healthy, she has lost the virility and vivacity of her early days. A ycar of two ago she would be in fit breeding condition early in Fehruary possibly, but with age and the artificial life she has led it is now absolutely impossible for her body to recuperate itself from the exhaustion and fatigue of the show season till tlee end of March, or the beginning of April. Her heedless, thoughtless owter pairs her up at the encl of January with a very vigorous, full-blooded young cock. What is the result? This young mate naturally wishes to commence the work of setting up housekeeping; he gets anxious and worries his lady love because she will not respond to his advances-she would if she could. He gets morc and more persistent, and so excites his mate that he stimulates her feclings, and her powers of reproduction are hastened instead of being allowed to develop naturally and quictly. Inder such circumstances can one expect the bost results? A noment's careful thought must, from the veriest tyro and most inexperienced of fanciers, give an uncquirocal negative.

CONSIDER THE VE'TERANS.

This being so, is it wise to attempt to rush our old warriers? They are, indeed, the flowers of our flock, and should be most carefully tended. A hen such as I have described, paired at the proper time, could go on for years delighting the fanciers at shows by her marvellous beauty, and her owner by her home bringing of firsts and specials, and the production of progeny which should even excel their parents in beauty and value. On the other hand, should she be paired up too early ere she is ready to respond to the 
love calls of her mate, what can one expect? Shellless eggs, undeveloped young dead in shell, fully developed babes brouglit to the hour of birth, yet lacking the necessary strength to break the shell enveloping them, and thus gain entrance to life, squabs which die in the nest, squeakers which, though reared, shuffle off to the haprer liunting grounds immediately the noult commences, because they have not stamina enough in them to withstand the strain on the system which the moult entails. Is this any fancy picture I have drawn? Is it not true to life? Is there one of us with any lengthened experience of the Fancy but what has seen many such cases? There can only be one answer to these searching questions, and that is a direct and unqualified No. What is needed in the following out of all general rules in regard to Fancy matters is more thought as to their apllicability to individual cases. How many an ardent young fancier wrecks his chances of success by generalising too much, and inclividualising or specialising too little? General rules and principles are needed, and are quite correct and proper in their place, but we must ever remember that the inclividual characters, dispositions, and constitutions of our pets must be studied in connection with those gencral rules which nust ever be adapted and conformed to local environment. Only hy so doing can we reap pleasure and profit from our treading out of the maze of the Fancy.

\section{THE QUESTION OF ENTIRONMENT,}

Some time since a friend asked:- "Do you think the embryo is likely to be harmed by unhealthy surroundings?" Most certainly I do. It is well-known that the shell of an cgg is porouts, therefore, through the pores the embryo must, of necessity, inhale any foulness of atmosphere which may surround the nest pan. It may be that the air of the loft is generally vitiated by some cause which is outside, and this, no cloubt, will have its effect n1)on the Young Pigeon, which is, or should be, growing to the perfection of unseen life. In a word, it is, I believe, quite possible for the embryo to be suffocated by impure gases in- 
haled through the shell. Another cause is that owing to the shell of the egg becoming coated with excreta, or other kind of dirt, the squab is gradually suffocated, whilst it should be developing.

\section{SLOW POISON, YET POISON.}

The more one studies this question of the reason why youngsters do not chip, the more apparent it becomes that unnatural surroundings have something to do with it. A loft which is kept closely shut up at night so that all the air becomes exhausted and vitiated is not likely to produce strong, healthy squabs. Neither is one in which too many birds are kept, for the exhalations of the inmates quickly renders the atmosphere poisonous. Like the old lady's stewed tea, it may be slow poison, but it is poison, none the less. It is many a day now since I went birds' nesting, but my memory does not recall many cases of young birds dead in the shell amongst the nests I stole; as a matter of fact, I don't seem able to call to mind one single case. I used, now and again, to find an addled egg, or an unfertile one, but never do I remember one in which the youngster had come to the hour of birth and then had not strength enough to chip the shell. We all know that the eggs of our wild birds are always beautifully clean and bright in the nest, and as for the atmosphere, where conld it possibly be purer? This, therefore, draws one to the conclusion that impure air and dirty lofts may have something to do with our young Pigeons being deacl in shell. Another thought strikes me as I write.

Eggs are sometimes dirty in a loft which cannot be so styled. When this is so, it will be found that one of the parents has dirty feet. Now, dirty feet are an unfailing sign of lack of stamina and ill-health. Adult birds which are in possession of a full flow of animal spirits, health; and vivacity, never have dirty feet. Unhealthy birds thus not only are objectionable, because they cannot be expected to procreate healthy progeny, but because, by their neglect of the ordinary rules of health they further handicap their progeny yet unborn by putting an extra weight upon 


\section{Pigeons and All About Their.}

their developing organism in the form of a shortage of rure air. If we study wild bird life carefully wo find that there is an abundance of fresh air, sun, and light vouchsafed to the nests of most birds, and, as a conseyuence, none of the drawbacks which affect Pigeons in a state of domesticity are developed. This leads me to reiterate advice I have often given before. If we would be successful we must keep as close to Nature as we possibly can. 


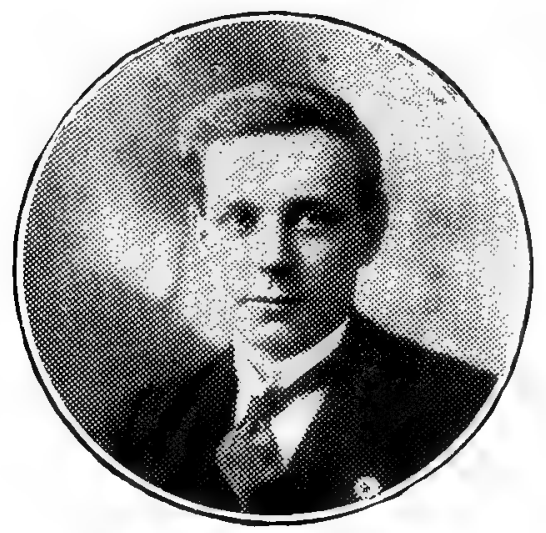

Mr. Harry Ingram.

An enthusiastic brecder of Exhibition Homers, Racing Homers, Oriental Fıillm. Jacohins. and T.F. Tumblers. A member of the E. F. Homer society and the Ince Fur and Featlor Societr. 



\section{CHAPTER VI. \\ CONCERNING PIGEON'S MILK.}

About twenty years ago the subject of P'igeon's milk caused some little excitement owing to the publication of an article advancing the theory that the milk secretion dicl not take place until the birds felt the movement of the young in the eggs which they had been incubating, and that such secretion was dependent upon the movement of the squab in the egg. Personally, judging from my own observations in a somewhat lengthy experience of Fantails, Owls, Nuns, Tumblers, Show and Working Homers, my conclusions are opposed to this. With Fantails, one gets more clear eggs than with any other variety, and it is not all unusual in a very high-class stud for seventy-five per cent., or even more, to be clear in the first rotnd; and as with birds of such a highly strung nervous temperament as Fantails, it would not be wisc to destroy the eggs and set the bircls going as soon as it is found they are unfertile, they are generally allowed to sit the whole time, or nearly. the whole time, before being disturbed. My experience has been when birds have been sitting on clear eggs that the milk, or soft food, has come just the same as when the eggs have been fertile, and often have I handled my birds on the fifteenth, sixteenth, and seventeenth days to discover if this were so or not.

\section{IN GENERAL AGREEMENT.}

It is generally considered that unless bircls are allowed to feed off the soft food that serious consequences are, of necessity, bound to follow. Whilst in the manner intended by Nature, I have never worried myself because my birds were unable to so feed it off. When I have not had youngsters to put under birds with 
clear eggs my plan has been to give two or three doses of Epsom Salts, and I have never had birds sick. Once, however, the birds have started to feed it is most essential for their welfare that they should go on. I am firmly convinced that the soft food grows very fast once its mranufacturing apparatus, so to speak, is brought into operation; and it is much more likely for a bird to go wrong, and very wrong, too, if it has feid for a couple of days, and then, owing to the death of its progeny, it is mable to go on. In many such cases the digestive organs seem to be completely upset, and it is advisable to take such birds out of the breeding loft, shut up their boxes and turn them into another house. I do not believe in putting them into pens, because the exercise they get is beneficial to them. They should be given al pinch of Epsom Salts, morning and night, fed very sparingly, and a little Condy's Fluid should be put into their drinking water each day. After four or five day's of such treatment they will, generally speaking, be guite themselves again. Then for three or four days they may be given Dixons' Tonic Pills, and by this time they can be returned to their breeding quarters.

\section{ANYO DOMINI 1786.}

This question of Pigeons' milk has heen an interesting one for many years; in fact, one might say ages, and some of our greatest scientists have spent much time and thought in research concerning it. More than nne hundred years ago, in 1786, one, John Hunter, lublished a paper on the subject with the title of "On a Sccretion in the Crop of Breeding Pigeons, for the Nourishment of their Yroung." In this paper Hunter demonstrated that a substance in the form of a little lellet, and resenbling in appearance the curd of milk, is formed in the lateral pouches of the crop of both cock and hen, for some two day's before, and seven to nine lays after the hatching of the eggs, and that the young squabs are fed exclusirely upon this for two or three clars, after which other substances are introduced into the dietary by the prarents. In all his investigations amongst birds he could not find instances of any birds except Pigenns, which fed their young in this manner. 
Jumping fifty years, and coming to the year 18.59 , Claude Bernard gives to the world the results attending his investigations into this most curious problem of Nature. Bernard found that this substance known as Pigeons' milk consists of masses of the cells lining the crop, but that these cells differ from the normal inasmuch as they are loaded with globules of fat. In Bernard's opinion the substance is more analogous to sebum or the oily substance formed in the bird's tailgland, and with which it preens its feathers, than it is to the milk of the mammal race of animals. This is in full accordance with the earlier investigations of Hunter, who agrees entirely with Bernard that the substance forming the soft food of Pigeons is entirely free from sugar.

\section{THE CHARGES IN THE CROI'}

The changes occurring in the crop membrane during the formation of the soft food, or when, as it was quaintly put $b_{y}$ Hunter, " the Pigeon gets in milk," are as follows:

"The crop of the non-breeding Pigeon is simply lined with layers of flat non-fatty cells, the total thickness of the cell-layer being apparently about the two hundred and fiftieth part of an inch. "These non-fatty cells are placed over small vascular papillæ. During the period of incubation these papillae grow, capillaries from their vessels penetrate the superposed layers of cells, which increase most rapidly in number, and manufacture fat. The thickness of the cell-layers is now about one-sixteenth of an inch, and the surface of the crop membranc becomes reticulated and pittecl. From now onward the fatty cell-layer becomes richly supplied with blood, contintes to grow at a great rate, and as new cells are formed in its deep strata, so whole masses are cast off at the surface, and this process occurring especially in the pits leads to the formation of the pellets of the soft food, or milk, found in the crop.

\section{THE STIMULATING AGENT.}

"As in the mammal, a fretus in utero is the stimt1lus to action for the mammary, or milk, gland, so here the incubation is the stimulating agent, and this 


\section{Pigeons AND Ali ABout TheM.}

leriod of incubation carried out by both parents, is the determining cause of those changes of the crop secretions which lead up to the production of Pigeon's milk. 'Two days before the squabs are due to be hatched, that is on the sixteenth day of incubation, the crops of the old birds will always be found to contain soft food, and immediately the squabs break through the shells and make their appearance in this world of care and sorrow the pellet apluears. These are lubricated by mucous secretion of the glands of the gullet, are raised by an action similar to that of retching, and immediately in response to their call transferred to the beaks and crops of the squabs. The marvellous manner in which a young Pigeon increases in weight often affords cause for wonderment, yet it need not when we consider the great amount of food which its parents pump into its cro1). It seems almost incredible, but it is beyond dispute, that the average quantity of Pigeon's milk jumped into a young squab each time it is fed by its jarents amounts to no less than two-fifths of the body rieight of the young bird. Is it any wonder they grow? When a Pigeon is deprived of its young it has to swallow its milk, and this it sometimes can do without aly evil effects; but when, owing to any disturbing cause, it is mable so to do, then crop sickness ensues, but if the birds are treated as I recommend ahove, the ill effects will be avoided, and the milk, as it is formed, will enter into the stomacl, be absorbed, and afford nourishment to the body. For three days when the old birds are in a healthy normal state the young squahs are fed entirely upon the soft fond secretions of their parents. From the fourth day unward to the eightl or ninth day, it will be found, if examined, that the crops of the young birds have within them a quantity of half digested and broken grain, in addition to the Pigeon's milk, but from the ninth day onward the supply of soft food is withheld, and the crops are packed with grain entirely,"

The analysis of Pigeon's milk made by Mr. F. J. Hambly, of iniversity College, Dundee, works out something like the following:- 


\section{Concerning Pigeon's Milik.}

Water

Albumen

Fat

Mineral

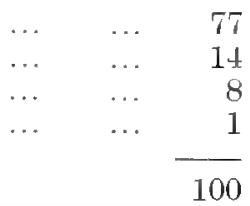

Taking the solids of Pigeons' milk only, Mr. Hambly found their constituent parts to work out as follows:

$\begin{array}{lllllr}\text { Albumen } & & \ldots & \ldots & \ldots & 58 \\ \text { Fat } & \ldots & \ldots & \ldots & \ldots & 37 \\ \text { Mineral } & \ldots & \ldots & \ldots & \ldots & 5 \\ & & & & & 100\end{array}$

THE NAME NOT A MisNomer.

There is much in the character of Pigeons milk which warrants it being called milk. For instance, the watery extract of Pigeons milk when treated with rennet, clots in precisely the same manner as does ordinary cow's milk when so treated, which indicates that it contains albuminous matter of the nature of casein, which chemists class with the family of the nucleo-albumens, the most nutritive of all the albumens. From the above, my readers will readily gather that Pigeon's milk contains ingredients of a highly nutritive nature-fat and nucleo-albumens.

This splendid nutritive article it is which accounts for the wonderful growth of the squabs. It is easily digested and made use of, for the bodies of the milk cells are digested off by the stomach above the gizzard, and the free fat globules found in the gut can be easily traced into the cells of the villi, and even to the leucocytes of the blood. The digestive ferments arc supplied by the squab itself, and not by the parent birds, for the milk as it leaves the crops of the parents contains no digestive ferments.

\section{NATURE'S PROVISION.}

As regards the meaning of this particular method of feeding, which is distinct from any other member of the feathered tribe, one can only sturmise that the 
natural forces of a young Pigeon are not so great as those of other birds. Nature, undoubtedly, working as she does, in perfect harmony with all her surroundings, has provided this peculiar food for the young Pigeon because it is obvious that the whole grain would be absolutely useless in the feeding of such a weakling as a young squab, from the fact that its gizzard membrane is so thin and friable that the microscopist has difficulty in its preparation for the lurposes of research, and it is so frail as most certainly not to be equal to crushing whole grain.

A young squab might, it is true, be sustained upon grain crushed for it by its parents, for the pancreas of the young Pigeon is quite equal to the task of digesting starchy matter, as is the case with the young of the mammal family. Indeed, as I have shown, after the first two days a few crushed grains are actually supplied by the parent birds with the soft food. Nevertheless, the fact remains that the bulk of the diet first supplied to a young. Pigeon in the early stages of its existence is composed of fatty and albuminous niatter.

\section{THE GROW'TH OF SQUABS.}

Those acquainted with the growth of young Pigeons know that a squab grows faster than almost anything else one comes in contact with. In fact, it is not too much to say that the manner in which a young Pigeon grows is simply astounding. During the first twelve days of its life its growth is phenomenal in its rapidity. After that stage the growth is slower. Seeing that the Pigeons milk almost, if not quite, ceases about the ninth lay, it is only reasonable to suppose that the marvellous development of a young Pigeon is, indeed, due entirely to its fatty and albuminous dict. The highly nutritive character of the milk lict is such that it lasts for a day or two after the milk lias been stopred, and as soon as the system has exliausted the last of the milk feeding, the mushroom srowth, so tn speak, is arrested, and the daily growth of the nestling becomes much slower. 


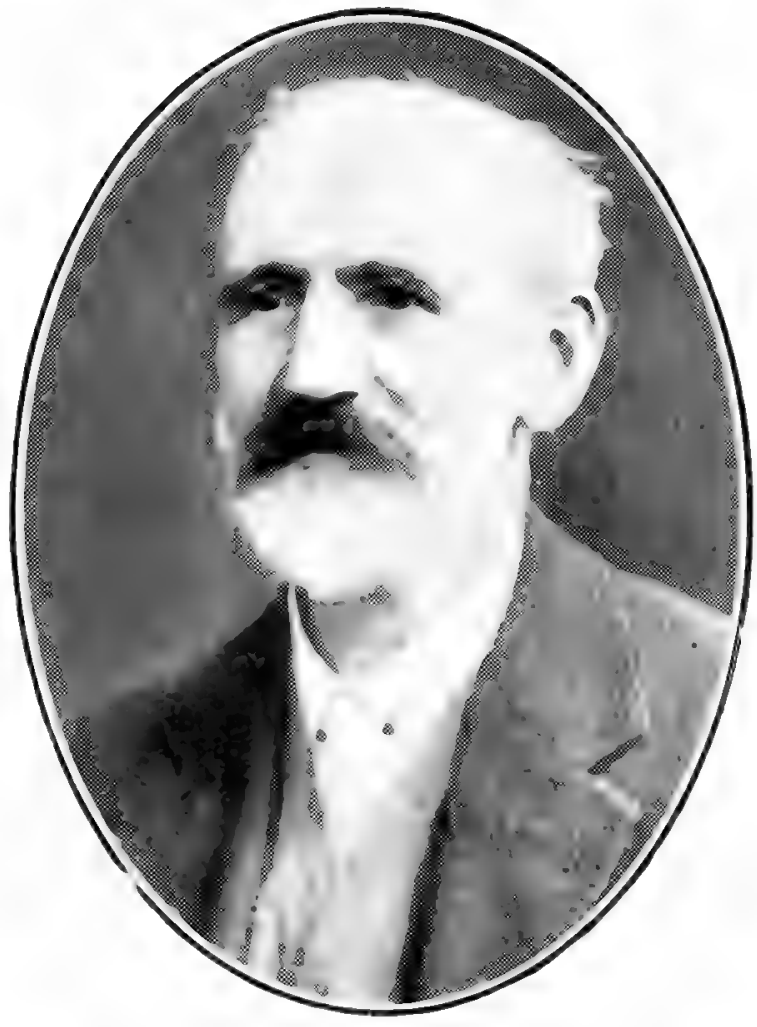

Mr. Jas. F. King, Egrove, nr, Oxford.

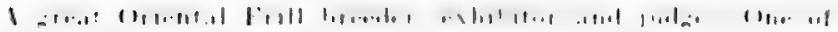
our oldest fancier's of the "Flowers of the Pigeon Fancy." Specialises in Black and Dun-laced Blondinettes and Satinettes. Has won the Interuational Trophy, Palace; Fulton Trophy, Dairy; and many other inportant prizes. 

There is a why and a wherefore in all plans of Vature, and it is wise to stop, at times ancl ponder thoughtfully over the lessons she wrould teach us. Now what are the lessons which this forcing of young Pigeons teaches us? That they are forced no one can deny. But why ate they forced? That's the question. As I have said before, Nature's works are all carried out in manner harmonious, and the reason why she provides for this forcing of the young squabs is doubtless because Pigeons being very free breeding hirds it is a matter of necessity that the young families should be got quickly out of the way before each succeeding family makes its apuearance. For much of the information which I have given my readers concerning Pigeons milk I am indebted to a paper read some jears ago hefore the British Association, by Professor Waymouth Reid, of Dundee I'niversity College.

\section{VIITT MUORE THOUGH'T.}

The following extracts concerning Pigeons milk is from " Voore's Columbarian," which was pul)lisher nearly two hundred rears ago, in 1785. This writer in language most quaint says :-

The young one's being usher'd into the World, naturally learls us to take a Vicw of the Manner in which it receives its first Sustenance. We have already mentioner soft Meat, which is nothing clse but a fine soft liquid Pal, 1repar'd as it were by Instinct by the Parents, by a Dissolution of the hard Grains in their Craw, against the time that the Futus is first disclos'd when weak, naked, and helpless; this soft Meat they throw up out of their Craw, taking the beak of their roung ones in their own, and by this Means injecting it into theirs; with this I Ieat the continue feeding them for six or seven Days, when they begin to mix some harder Food amongst it, 'till at Length they feed "em with all whole Grain." 


\section{CHAPTER VII. \\ THE MOULTING SEASON,}

The moulting season is an anxious time witl most fanciers; anxiety is caused during its progress in many ways. It is during the moult that many a pronising youngster is made or marred. The moult it is which finds out the weak spots in a bird's constitution, and the moult it is which causes to develop faults and failings not seen in the first feather. On the other hand, it must also be said that many a bird little tllought of before the moult blossoms out into a wimner of firsts, specials, and cups owing to the care bestowed upon it, and by the manner in which it comes through the moult.

The moulting, or the changing of plumage in birds, is like unto the shelding of their foliage by the trees. The process is somemhat similar, and ret it is altogether different. Similar in so far as shedding of the plumage is concerned, but totally different inasmuch as a bird, in addition to shedding its old coat. has to grow a new one at the same time, a process which the tre delays till the springtime. The leaves on a tree grow and grow till such a time as their veins are filled with the matter from which they obtain life. There is then a susprension of the growing process, and the leares hold on for a time; but owing to the fact that in leaves, as in other things, there can be no life without circulation, so after a time the leaves begin to wither and then (rop) off. In somewhat the same manner does a feather grow, then gradually loses its strength, and drops away.

THE COMPOSITION OF A FEATIEER.

To thoroughly anderstand the moulting of a Pigeon, one needs to have some linowledge of the structure of feathers. If we take a feather and carefully cxanine it, we find that it is, roughly speaking, com- 
posed of three parts-the quill, the shaft, and the vein. By the former is the feather held to the skin of the Pigeon, the shaft grows out of the quill, running up the centre of the feather, and to the shaft is the vein attached. The feather grows and is nourished directly from the blood through a small opening at the bottom through which the sustenance for the feather is drawn during the whole time it is growing.

This, like the veins of the leaves of a tree, in time becomes choked $t_{y}$ the accunulation of the secretions of chemical matter, and the feather, like the leaf, falls away from its support, because it is no longer nourished and strengthened.

The moulting' process is marvellous when one comes to think of it. At this time the Pigeon, in common with other birds, from the elements contained in its own body, produces the forces which cause its old coat to be cast off and a new one to grow in all its living, glowing pristine beauty. We are so used to this wonderful process that we never stay to think of its miraculousness. Did we first sce a bird moult without knowing anything about it we should be awestruck by the wonderfulness of the mystery; but lucause we grow up with it, and our eye is trained to it, we fail to stop and think of all that the process is and means.

\section{LIFE PRODUCES LIFE.}

In the monlting of a Pigeon the old is replaced lng the new, as in many other things. Life produces life, and from the decay of life fresh life springs. The moult commences with the desiccation of the old feathers. The quills become dry and sapless, all the sap is clried out of them, they lose their strength and firmness, the web loses its lustre and depth of colour, the quills shrink within their sockets, the surrounding skin becomes shrivelled, and like the leaves on the trees they drop off.

Immediately the old feather has clropped out the new begins to fill its place, even if it, like the second tooth of a child, has not already had something to do with the ousting of its forerunner.

It is obvious to all, even the merest tyro in natural history, or orni- 


\section{PigeONS AND Ali ABOUT Their.}

thology, that the time of the moult must of necessity be a time of severe strain to the birds. Not only have they to keep up the natural forces of their body, but they have also to sulpily from the source of these forces the material or food, to grow another crop of feathers. This must naturally have a most exhausting and enervating effect upon the internal economy of birds undergoing the process. This being so, it becomes our duty to see what we can do to assist our pets to go through the moult with the least amount of discomfort possible.

\section{WARIITH A FACTOR.}

First and foremost we know that warmth is a most desirable and necessary factor in the accomplishment of a quick, healthy, and successful moult. A quick moult is usually a healthy moult, and a healthy moult is, generally spcaking, a successful one. Nature herself has chosen the most fittine time-the end of Summer, when the earth is full of heat from the rays of the sun which have been pouring down upon it for some weeks, and which keeps the nights almost as warm as the lays; as at night, when the sun is not shining, the earth gives off its stored heat, thus equalising the temperature of day and night. To secure the full benefit of this provision of Nature we want to see to it that the moult in our stock is not delayed. An early moult is a quick one. A late moult is a slow onc, caused by the fact that the atmospherical surroundings are not so favourable, and that as a consequence the moult is retarded, and very often unforesecn and unctesirable complications ensue.

With the end of June fanciers should begin to think of putting away all the appurtenances of the rreeding season. The snoner breeding is finished the sooner will the old hirds drop into moult - that is, the body moult; the hig quill fuathers are already on the move. In this connection it should be noted that the older a Pigeon becomes the longer it takes to moult. Thus very old and choice favoutites of the loft should not have more than two nests of youngsters taken from them, so as to ensure their getting well through the 


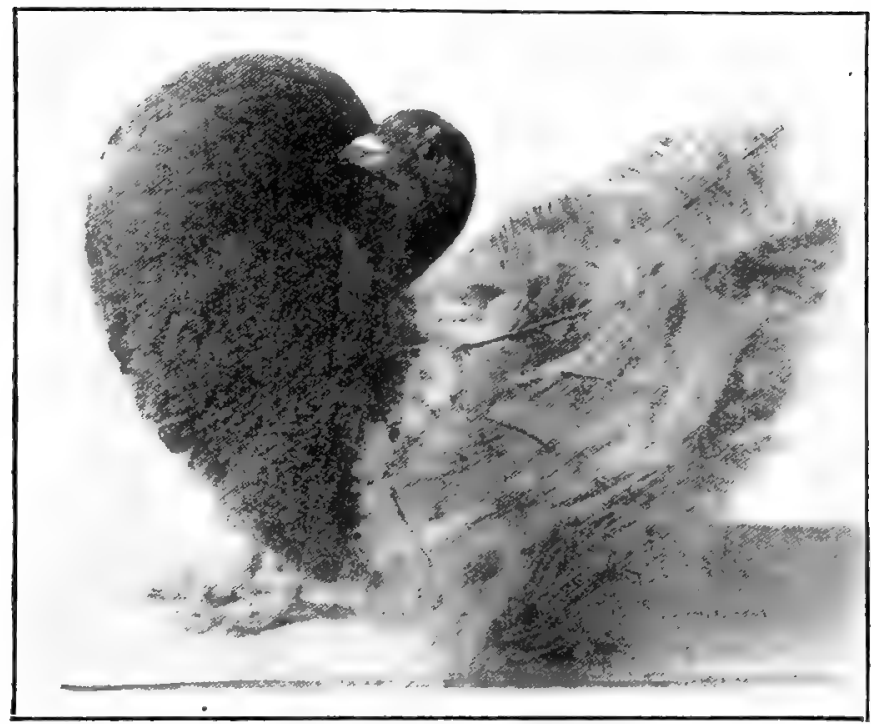

\section{Red Lace Fantail, "Autumn Leaf."}

Winner of the Lace Cup in 191\%.

Bred and Exhibited by Mr. R. Charles Hall. 

moult. Some time since a young fancier, a first season man, came to me in great distress. He had four pairs of hirds up, and he had not bred a youngster. "What shall I do to get my hens to lay? They go to nest, and sit! sit!! sit!!! But they will not lay." I discovered in the course of conversation that his stock was pretty old ere it came into his hands, and that the hens were bred with late the previous summer. Their previous owner did badly, and bred late on in the season in his endeavour to repay himself for the early misfortunes. As a consequence, the hens were so pumped out that they had not laid an egg-not one of the four! Their present owner wanted to know what he could do with them. My advice was, "Stop breeding at once, get them moulted through early, give them plenty of flying room, and then next season you might be able to get something from them."

\section{CHILLS TO BE AVOIDED.}

Warmth being an essential factor in a successful moult, fanciers should see to it that their birds are enabled to get the full bencfit of all the warmth which the sun gives, and that they are protected from draughts, and also from damp. Draughts and damp are fatal to Pigeons under any circumstances, more especially during the moulting season. So serious are the effects of a chill caught by exposure to dranght or damp during the moult, that they often check the moult altogether, causing the birds unnecessary pain, consequent illness, and somctimes death, and even if death does not supervene the birds are reduced to a poor state of health, and never recover sufficiently from the effects of the bad moult to be ready to take their places in the breeding pens later on. During the moult birds are more or less without their full complement of clothes, and thus are very liable to attacks of cold or chill. Therefore, it is the more necessary at this time to exercise the greater care in their management.

\section{A LIRERAL DIETARY NEEDED.}

During the monlt the feeding should be of a liberal and generous character. The corn given should be 
of the very best, and may contain a fair quantity of wheat and maize-that is, compared to what is given at other times of the rear. The wheat is somewhat laxative in its nature, thus keeps the bowels working freely, whilst the maize is stimulating and fattening, and thus does good service at this time in that it keeps flesh on the bodies of birds that might be apt to get low in condition. " are much helped by a little maize during the time they are in the moult. If the dietary consists of equal parts maple peas, tares, wheat, and maize for the stronger varieties, good feeding will be provided, whilst for the smaller, and more delicate, not necessarily more delicate in constitution, but in appearance, in feather, and general character, using the word more in the sense in which it is connected with things beautiful, the maize should be omitted. Another most valuable adjunct of the clietary table of all Pigeons during the moult is Siratt's Pigeon Food. Being a cooked food, it is so much more quickly and easily digested than raw grain. 'Thus, it provides the birds' systems with nourishnent without half the expenditure of nerve force that grain needs to digest it.

\section{ESEFTL STIAITLANTS.}

For birds which are hanging in the moult and casting their feathers very slowly new wheat is a grand food; it is most stimulative and sets the feathers falling quickly. For slow and late moulters it is invaluable.

IIany fanciers give their birds pick-me-ups, and conditioners, such as hemp seed, linseed, canary seed, ctc., cluring the moult, and all with the desire to stimulate and nourish the body. I am not a great adrocate of hemp-a little of it goes a long way. In large quantities it has a prejudicial effect upon the liver, and is also apt to render the feather soft and coarse. I mean, of course, when given excessively. A little hemp is all very well. Then as regards the linseed; few Pigeons will eat it readily. The valuable properties of linseed are known to all who have any practical experience of getting animal life into good bloom and condition, but whilst breeders of horses, cattle, and 
other animals have little trouble to induce their stock to eat it, Pigeon fanciers have great difficulty. The great value that linseed is to the stock breeder is because of the valuable effects of its oil upon the coat. Owing to modern enterprise and skill Pigeon men are now able to administer to their birds the active principle of linseed in the shape of linseed oil capsules, and that their value is known and proved is shown by the big demand there has been for them since their introduction by Mr. R. Woods. Of canary seed, and its value as a conditioner, I have often written. Pigeons are madly fond of it. Its great value comes towards the end of the moult when the birds need tightening and hardening up in plumage.

\section{THE VALUE OF TONICS.}

A most excellent tonic and stimulant during the moult is iron, but to secure the best restlts from iron it needs to be mixed with other substances. The best form in which it can be given to birds is that known as saccharated carbonate of iron; the iron being chemically treated in some manner with sugar becomes much more nutritive and effective. Iron in any form is useful during the moult, but this particular form is the best. I have reason to believe that several of the tonics in pill and capsule form which are on the market contain carbonate of iron in some form or other, and these pills and capsules are much to be preferred to any home-made mixture. A most excellent capsule is that which contains Extract of Malt, Cod Liver Oil, and Parrish's Food. Long feathered birds such as Fantails, Jacobins, Trumpeters, etc., can be greatly assisted if given Woods' Compound Sulphur Pills. which are compiled from a formula of my own, and successfully used amongst my Fantails for many years. The ingredients in those pills are all conclucive to quick and strong feather growth, and as they are the result of many years' experience in my orn loft, I know their value. 


\section{CHAPTER VIIT. \\ SUCCESSFUL EXHIBITING.}

"In wonderful fettle,", "Beaten in feather," "Not in such good form," "Won by condition." How well known are such phrases as these, not only to the frequenters of shows, but also to readers of the reports which appear in the weekry paper, "Pigeons.." Few, very few, are the points given for condition in any standard, yet how great a part it plays in the decisions of our judges. Some may argue, too great a part. I think not. It matters not how good a bircl may be in structural proportions, beauty of plumage, or excellency of marking, it cannot show these points to perfection unless it is in good condition. Therefore, our judges cannot insist too much on exhibits being in good condition, neither can they appraise ton highly the efforts of those fanciers who put their birds down as fit as the proverbial fiddle. Condition is to the exhibitor what possession is to the litigant-nine points of the law.

\section{CIEANIINESS A VIRTTE.}

No matter how excellent an exhibit may be as regards its standard properties, it cannot slow off its beauty unless it is shown spotlessly clean, and with its featleers tight ant smart. Te all know the elifference in the appearance of a hird that is fit and one that is not, and we all apreciate that clifference. It is this appreciation of condition which has made the Barb and Carrier men protest somewhat of late against the giving of prizes to hirds which, althung marvels in regard to structural properties, have yet in the pens looked of all birds most miserable. Tnder some of our judoes, if a bird had a bic head, a stout beak, and plenty of cere, he would get well ui', no matter if half its feathers were glued together with dirt, and the top and bottom 


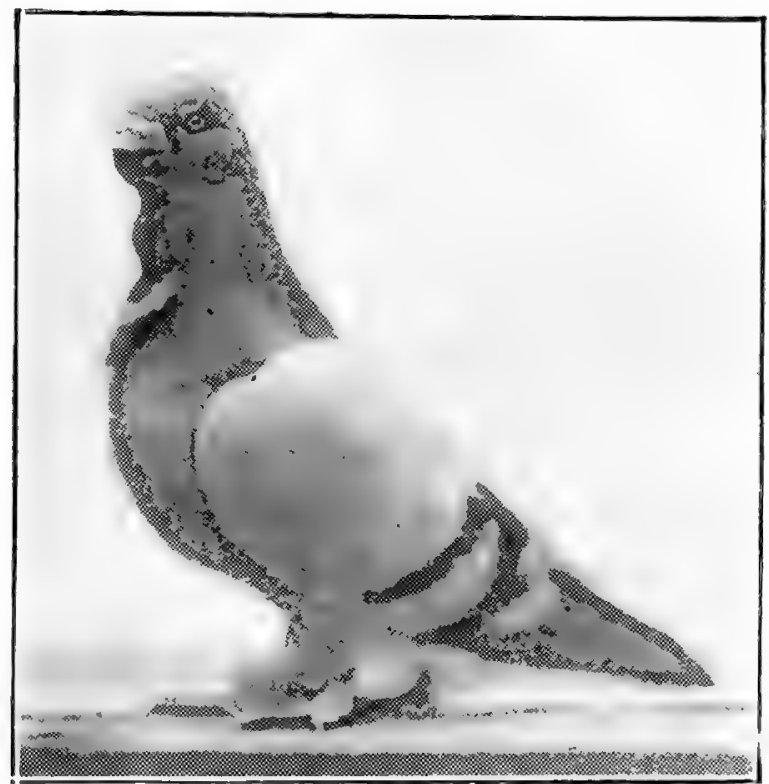

1914 Blue English OwI Goch, "Lord Kitchener."

One of the best Owls of his day, and winner of many prizes, including 1st and spl. best adult English Owl Dairy, 1st and spl. Keighley, 1st and Cup best Pigeon Ilkley, 1st Otley, 1st Paisley (twice), 1st Glasgow, etc.

Bred and Exhibited by Mr. Prince Smith, Junr. 

jortions of its ceres held close by an aclmixture of dirt and mucous discharge from the eyes. Beauty we all admire, but there is no beauty about a Pigeon dead out of form; and such a bird ought not to be recornised by our judges. Some will have condition; others are not so particular.

\section{WHY BIRDS FAIL TO WIN}

Many birds which should and could win are left carclless because they are in the moult.

There are some who never think a bird is out of conclition tunless it is ragged in feather from the moult. Then they can see it, and will say, "Look at its condition! What could you expect?" I think little of the absence of feathers during the jrogress of the moult. The bird at that time is going through one of the natural processes of its existence. It must moult to live, and it is quite possible for a bird to be deep in the moult and yet in splendid condition. Its feathers may be clean, its eye bright and clear, its flesh hard and firm, its carriage and action smart and lively. No! the mere fact that a hird is moulting does not imply lack of condition. It certainly does mean that it is not in full beauty of plumage, and it should not mean more in a bird that is well looked after. I grant that it is more difficult to keep a bird in condition durnng the moult than at anv other time, but this is hecause in addition to supplying its body with its necessary strstenance it has also to grow a new coat.

\section{STMLIER SHOWING.}

Year by year are our Summer shows growing in number and importance. Some few years since such shows were almost all held in the North, but now South country fanciers have many a little flutter in the Summertime, and the tendency is towards more and more of these summer outings. As these fixtures increase in number and volume year by year, it is incumbent upon those fanciers who would move with the times that they should have a few birds in good form for Summer shows. Some there are who keep a few birds on purpose for them. They, of course are, in 


\section{Pigeons ANid All Abot' Thenr.}

the early Nid-Summer months in good form, because being free from parental cares they are sleek and tiglit in plumage, and their eye full of fire and vigour. It is only those fanciers who have plenty of accommodation and a fairly large stud who can afford to run a few birds over for the Summer shows. Those who are able to do so reap a rich reward, as many a good first and special may be picked up at these shows by birds which, in the Winter season, would play second fiddle to the first violins.

The birds that have been held over and freed from the cares of a family usually moult early, and thus are often " as ragged as coots " during August when, both in the Nortl and the South, there is most to be won at these Summer shows. Therefore, something else has to be found. It cannot be the birds which commenced to breed early, becalse they, if anything, will possibly, and most certainly should, be more forward in the moult than those which have been held over. Therefore, the birds which should be in the best form for the August shows are those which are not paired up early in the year. This is a point which is not given the attention it should te br fanciers. Birds which are paired early invariably moult early, and those that are paired late to not cast their feathers either so carly or so swiftly as those which go to nest early in the season.

\section{WINNING AT HOME}

There are many fanciers who never dream of sencling away to a Summer show yet who like to support any local fixture that may be heli within reasonable distance of home; and there are many reasons why they like to support "home industries." - A man is not without honour save within his own little circle of acquaintances. He may send away to the Dairy Show. Crystal Palace, Manchester, Barnstaple. and other big events, but what are they compared to the little flutter in connection witl the flower show at Slocum-on-the-Mud? Nothing-a veritable nothing! The local folk hear these events talked about, and are told that their friend and neiglibon wins at 
them. He must win at Slocum-on-the-1Iud, then they will believe he has some good Pigenns. With them, seeing is believing, otherwise they are doubting Thomases one and all. Then, altlough one may be able to win at the big classical events, there is a desire to do well at home at the little insignificant, unimportant fixture, which if it were fifty or a hundred miles away one would ${ }_{1}$ ot give a second thought to. It is the desire to win local approbation, to stand well in the eyes of our every-day friends and companions, which causes us to wish to win at the local event-and how much some of us have sactificed to win this local esteem for our birds! How often has a winner of a first and cup at the Palace, or some other big fixture, been trotted out for the little home event, and had to bow its proud head to some bird not worth as many shillings as our champion was worth pounds; but that, bitter though it has been, was nothing to be compared to the gall and wormwood of being beaten on our own ground, and before the eyes of our bosom pals, who have not forgotten afterwards to rub it in.

\section{GETTING CONDITION.}

Now, as condition, or the lack of it, has much to do with the awards at Summer shows, I wish to lead some of my young friends into the desired way of obtaining it. When birds which have been attending to the requirements of the later nests of young birds are relieved of their parental responsibilities they should be allowed plenty of flight room, fed rather sparingly, and upon as non-heatin a diet as possible. For the first few days after leaving the young they should be given a pinch of Epsom Salts morning and night. This will cool their blood, cleanse their systems, and assist in keeping their jackets intact. They should be given a bath every other day to cleanse and brighten their plumage. Birds of the wattled varieties will need a more searchin $r$ preparation than those belonging to the non-wattled breeds. During the breeding season the birds with heavy wattles and ceres become very much messed un about the head, and unless this is put right the chances of such are seriously jeopardised. 
Some exhibitors presume on the fact that judges do not like to pass the champion birds, and thus will not take the trouble to put them down spic and span. I hardly know who to blame most-the judges who allow such presumption to grow up in exhibitors' minds, or the exhibitors who presume. Most of our schedules say " the prizes shall be awarded for beauty of plumage, high quality, and condition," etc. Now, how can there be beanty of plumage and high condition in a bird which is smothered in dirt?

\section{TONING UP.}

Before a bird is sent to a show it should be given a few of Dixon's Revivers to tone it up a bit and two days before the show-that is, the day before being sent off, the wattles-if it is a wattled varietyceres, legs, and feet should be well washed. The sponge, soap, and water will do all that is required about the legs, feet, and ceres, but around the mouth, nostrils, and wattles, the tooth-brush will come in useful. The wattle in wattled birds, should be opened in all its crevices, and the brush well soaped, carefully inserted, then the sponge should remove the dirt by the aid of water. Not only will this cleanse the wattle, but it will make it soft and pliable for a time, and by a little manipulation its appearance may be greatly improved. After the sponging has been well done, the ceres, wattles, face, etc., should be carefully dried with a soft towel, and a little violet powder, or Pear's Prepared Fullers Earth dusted into the crevices of the wattles. Not only will this cleansing add considerably to the appearance of the bird so treated, but it will also greatly increase its comfort.

\section{CATCHING THE EYE OF THE JUDGE.}

A bird so cleansed will catch the eye of the careful judge much before one that is dirty and greasy. When a bird is put down clean and smart it looks as though the owner takes a pricle in the appearance of his stock, and it is only fitting that his labours should be rewarded. There is one fancier whom I know who is most assiduous in the care and attention which he 


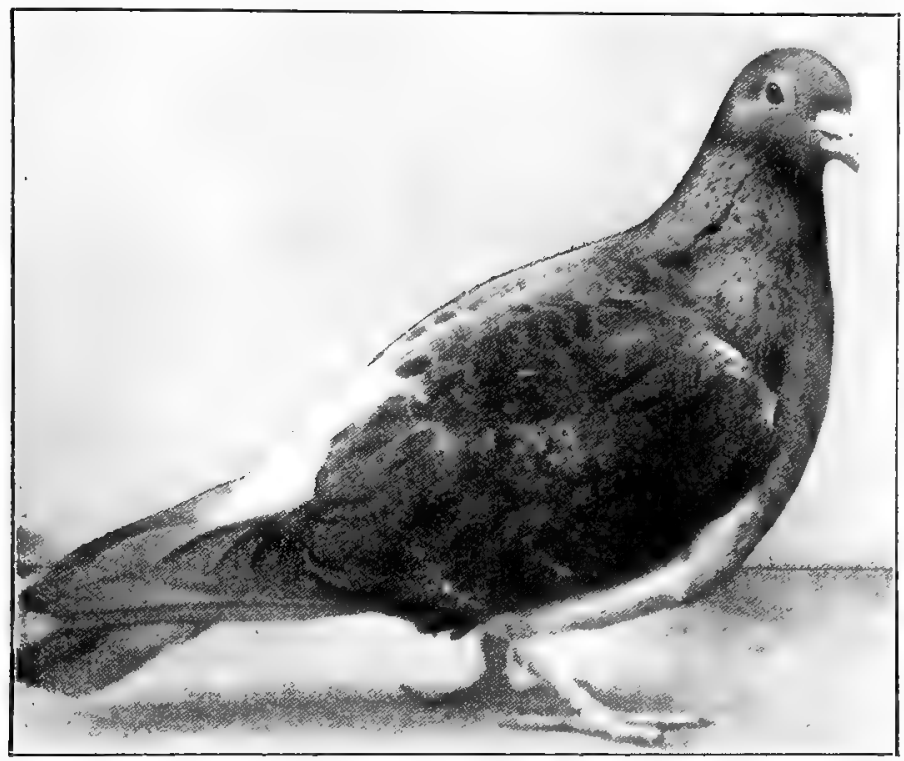

Pure smerle Hen.

The "Twice Marennes" Hen.

Won all races up to and including Marenues (375 miles).

Bred and Trained by Capt. St. John Hornby, R.N. 

bestows npon his birds, and the result is to be seen in the innumerable firsts and specials which he captures. Yet more than once have I heard fanciers envious of his success depreciate his birds and his labours by saying, "He's no fancier; he's only a showman." In a way their depreciation adds to the honour gained by the man they belittle, for if he works, as he does work to secure his reward, that reward must be sweet to him, and well deserved. A good bird deserves to be well shown, and a moderate bird even is much im1)roved by being well shown. Condition should be a far greater factor in the awards of our judges than it is. A man who is careless of the condition in which his birds are shown is not, and cannot be, a true fancier, because he does not consider the health and comfort of his birds. A bird in good condition is a bird in good health, and a bird in good health is happy and contented, and enjoys life as well as his master, who should, in return for the labour which he bestows on his pets, receive all the encouragement that can possibly be given him by our juclges.

The spoils are to the victors on the battlefields of the Fancy, even as they are on fields of a more martial character. Victory usually rests with the leader, who comes into the fray with his guns all trained, his powder dry, and his men fresh, fearless, and confident of rictory attending their prowess. In a word, the man who never shows his birds unless they are fit, and only tnder men who have the knowledge and experience necessary to appreciate their merits, is the man who attains success.

\section{ETILS OF OVERSHOWING.}

I wish to sound a warning note against the overshowing of birds, and of birds that are not fit. A glance through the reports which appear week by week in the columns of "Pigeons," will show that some birds do three shows a week. This is little short of cruelty. If the shows are one-day fixtures within easy distance of home, and the birds are taken to and from shows by their owners, there is nothing wrong in three shows a week, because the birds can perch 
in their own loft each night, and get a drink and feed at home, both before and after the show. In such circumstances little liarm can cone to them. But when the shows are some distance array from home, and they have to travel by themselves-in some cases going from one show to another-how is it possible for them to keep, up in condition? Seldom getting a good feed, having to drink pollited water day after day (a glance at the drinking tins at our shows speaks for itself) having to sleep in a show pen or a basket fire nights out of seren, and only ably to get a good wash once a week-how can they keep in condition?

It is really amazing the amount of thoughtlessness shown by some exhibitors. To endure what they are asked to endure, their Pigeons would need to be as strong as a horse. In the midst of so many handbooks on Pigeons, and such a number of practical articles as appear almost every reek in "Pigeons," it does sem strange that men are still to be found who have ret to learn that the first state of an exhibition Pigeon is that known as being "fit."

\section{ONERSHONING KILS MINY GOOD BIRDS.}

When this takes place their owners have much to say to their friends about the bad luck they liare met with in the deatli of sucl grand birds-such noted winners! Vet they thenselves will have been responsible. If fanciers will not stuty the care and comfort of their birds, and treat them in a natural and humane manner, they certainly cannot hope for success in the show per1. Good birds ileed to be well shown to reach the top of the tree.

When birds have to be sent away from home to show's without anyone in attendance, one show a week is quite sufficient. In fact, that is really too much if it is kejt u1) regularly without a break for any length of tince. Some of our best fanciers never show their choice birds more than three or four times in a season. They know that if they do over-show them ther will not be able to procreate their kind in the Siring, when the breeding season is mon them. 


\section{RFGULAR ATTENTION NEEDED.}

It is impossible to keep a bird or animal right up to concert pitch for a longer period than forty-eight hours. This being so, it will be seen how recessary it is for birds to be given regular attention unless great inroads are to be made upon their constitutions. I urge this not altogether to assist my readers to win 1rizes, but because I have an intense love for the dumb creation, and it pains me to see Pigeons tortured by the thoughtlessness of their owners. I like to see a Pigeon with its eye bright and clear, its head held firmly, its tail expanded as it bows and sweeps round the pen with a merry joyous coo. In such a state a bird appeals to my sense of the beautiful, and also to my critical faculty as a judge. But when the eye is closed, the head held listlessly, the wings drooping, and the tail resting on the floor of the pen, my feelings are outraged.

Condition is nine points of the law in showing, vicwed only from a selfish standpoint-the desire of victory. But above and beyond this it is every man's duty to keep his pets in a fit and healthy state, so that they may enjoy life even as does their master. 


\section{CHAPTER IX. \\ THE WASHING OF PIGEONS.}

Those whom duty or pleasure has taken to any considerable number of exhibitions will have noticed that where one pigeon shows sigus of being well washed there are many that look as if their introduction to the bath had resulted in their last state being worse than the first.

Many there are who are so nervous, and so afraid of injuring the subject of the bath, that they dare not make the attempt. Now it is absolutely needful for the town dweller, if he keeps any of the lighter plumaged varieties, to know how to wash. Birds cannot be kept absolutely spotless in plumage in a district where smuts and smoke abound. To such an one the knowledge of how to wash makes all the difference between success and failure in the show pen. The man whose ariaries are situated away in some delightful country dell, on an open hillside, or near the boundless ocean, has no need to worry about washing. So clear and bright is the atmosphere in which he and his pets live that lack of condition through atmospherical surroundings is unknown to him.

\section{DO TT WELL OR NOT AT AIL.}

It is not at all an easy task to wash a Pigeon unless you are in adept at the practice, and few, very few, are the fanciers who can truthfully say that they are experts in the art of washing. One thing must ever be remembered, that if a bird is badly washed it looks worse than it would have done had the attempt not been made at all. The washing should be done thoroughly and smartly, or else left altogether alone.

At the outset I would say: Never wash a Pigeon unless obliged to do so. A newly washed bird looks very handsome and smart, and an occasional tubbing 
is, I think, conducive to health, but the evil of it is that once. one has started to wash a Pigeon for exhibition, the practice has to be kept up, and every twice or thrice that the bird leaves home for a show necessitates the process being gone through. Now constant washing, I feel sure, cannot be to the advantage of the bird's constitution, and it certainly does not improve its plumage. After a bird has been washed two or three times, the feather loses its soft, silky nature, and becomes harsh, hard, and dry looking, having a sort of cottony appearance, instead of a silky look, whilst it must ever be remembered that once the washing has commenced it must be continued, because a bird once washed very quickly soils. Still, after all these drawbacks have been considered, the question left facing us is that unless town-kept birds are washed they cannot win; and, therefore, washed they must be if success is to be achieved.

\section{SUCCESS NOT EASILY OBTAINABLE,}

Success in washing is not attained all at once. In a laundry the girl who gets up all the fine laces and collars is not a new hand; she has had to serve an apprenticeship by doing some of the coarser work, and thus get both her hand and eye in. It is the same with washing Pigeons. The novice cannot hope to turn out a bird in the same style as one who has washed season after season. Practice makes perfect. In the commencement it is wise for the novice at washing to try his 'prentice hand on some of the wasters in his flock. It not infrequently happens that at first disasters occur, and if they do occur, it is far better for a bird of no value to be sacrificed than for one that is likely to score well in the show pen.

In washing Pigeons, as in all things, there is a right way and a wrong, and if success is to come it must be through the adoption of proper methods. It is no use attempting to wash Pigeons unless you set about it in a proper manner. The safest and most convenient time is the erening. In the first place, the house is quiet, and one is not so likely to have 
the operation interfered with by members of the household, and the operation is not so likely to cause annoyance to those upon whose shoulders falls the work of the house. Further, the evening is the best time for the birds. A bird should be washed after it has had its erening meal-though not immediately after-so that the food in its crop may digest and nourish it during the hours intervening between the washing and the next morning. If birds are washed upon an empty crop they are more apt to be upset than when they have some food inside them; they also are not so likely to recover from the exhaustion so quickly.

\section{THE KNACK OF HANDLING.}

There is much in the knack of handling Pigeons in the washing process, and this takes some little time to acquire. It is not at all an unusual thing for a novice at washing to pull out a few flight.or tail feathers, even if he does nothing worse; but practice makes perfect, and in a very short time the average individual will have secured the necessary confidence and knack of handling the birds, and he will think no more of putting at team of birds through the order of the bath than he will of taking his own matutinal dip. Confidence in one's own powers is the great essential; that secured, all else becomes easy.

The first washing is approached with much fear and trepidation, and although a fancier may have been told how, also have read very carefully this chapter on washing, he will be one by himself if he can commence on his first bird without any qualms of fear as to the result. It is all very well to read, or be told, how it is done; it is another thing altogether to do it. Reading and hearing about such things are good so far as they go, but seeing is $I$, ooo per cent. beyond them. More, far more, can be learnt by seeing another fancier put a bird through the bath than can be gathered from being told a dozen times. This being so, if there is any possible chance of seeing some skilful operator perform, that chance should be accepted. If the novice has the acquaintance of some fancier who is an experienced 


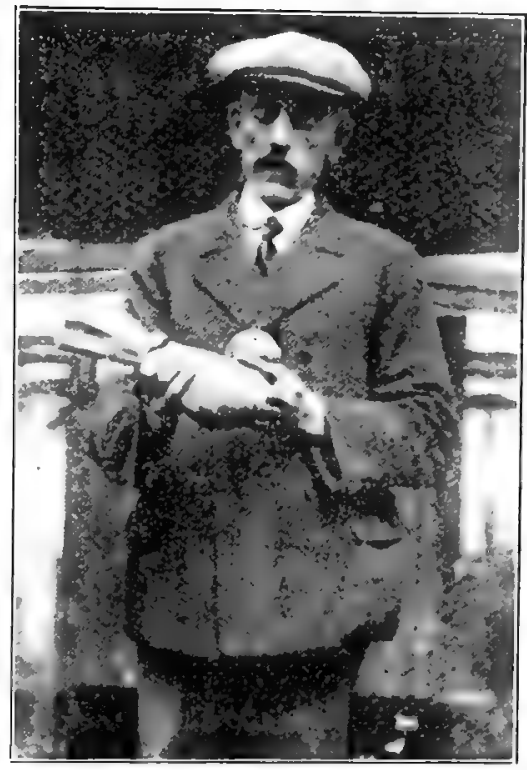

\section{Mr. G. A. Pelling (Stud Manager)}

Handling the sensational Yellow Chequer Cock owned by Mr. W. A. Murray, and for which three different offers of t100 have been refused. 

exhibitor, he should politely, yet boldly, ask to be allowed the privilege of seeing his friend put a bird through the process. Not only will an ocular demonstration show him clearly how to proceed himself, but it will also remove all or much of his fear as to the successful issue of his first attempt.

\section{VALUE OF A GOOD START.}

In the washing of Pigeons, as in many other things, a good beginning goes a long way towards a good ending, and if one is to feel that all's well that ends well one must start right. In the washing of Pigeons one must keep on the track the whole time, as the operation is a continuous one, and any slight deviation from the right road may spoil the whole of one's work.

To start with, a good steady fire is needed, and the best way to secure this is to commence by well stirring the fire, getting all the dust out of it, also pieces of slate and other objectionable matter. Then proceed to build it up so as to get the full value of its combustion. This can best be done by using equal quantities of coal and coke. Nice knohby pieces of about the size of a cricket ball, not larger, because if larger they will require smashing on the fire, and thus spoil the gradual combustion which is required, and also waste a quantity of heat. Dusty coal must not be used, because the gas in it is quickly liberated, gives out great heat for a short time, and then your fire becomes a dead mass. A fire made up of small, even pieces of coal and coke burns steadily, and throws out a nice steady heat, and this is just what is required to dry the birds properly. Further, a fire so made produces less smoke and less ash, two very important considerations, especially if one is washing a large team of from twenty to thirty birds, as 1 have done before now.

\section{GETTING READT.}

During the time the fire is burning up, the articles necessary to a successful wash may be collected together. These are three good-sized bowls-bed- 
room wash-basins are as good as any, and about the right size. One is required for the washing, one for the first rinsing, and one for the final rinse. A small honeycomb sponge, a nail brush, a tablet of soap, three or four nice soft towels (old discarded Turkish bath towels answer the purpose best), a big jug of cold water, a jug for the hot water, a bottle of glycerine, and the household blue bag.

The soap plays an important part in the proceedings, especially if birds of a delicate colour are to be operated upon, because coarse common soap contains a lot of free alkaline matter, and this acts prejudically upon the colour. High-class suap is more carefully made, its ingredients are purer, and it does not injure either the plumage or its colour. Most fanciers have some particular kind of soap which they consider best for the purpose. Thus, whilst one swears by the old-fashioned Brown Windsor Toilet Soap, another will only use Glycerine Soap, another is wedded to Castile, whilst all the talk in the world would not convince some that White Curd can be improved upon. The truth of the matter is that all these are good, as is any carefully prepared toilet soap. My opinion as to the best soap for the purpose is that Spratt's Poultry and Pigeon Soap is the best. Not only is it as carefully prepared as the best toilet soaps from the purest ingredients, but in its manufacture thought is given to the special purpose for which it is to be used, and in addition to the cleansing ingredients in its composition there are also others whose special work is to destroy any insect life which may be concealed about the plumage.

\section{HOW TO DRY THE BIRDS.}

In addition to the washing utensils, something is also needed in which to dry the birds. Some fanciers use a drying box. That is, a long box about three feet long, eighteen or twenty inches deep from back to front, and about the same in height. This has wooden top, bottom, ends, and back. The front is of open wire work-often the fronts of a couple of Pigeon or Bantam pens; some use a Poultry pen. 
My own choice is a large round Poultry hamper. This I have covered with sacking three-parts of the way round, leaving the rest open, so that the warmth of the fire may the more readily and easily reach the birds, and allow me to see how the drying is progressing. The bottom of the basket I cover with cut hay or straw, oat or wheat husks. This prevents the plumage from becoming soiled by the excreta which the birds may void whilst in the basket. A very important consideration is this, because if a Pigeon's feathers become stained with anything whilst they are wet, or partially dry, it is a most difficult matter to restore them to their pristine beauty.

The cloths which are used for drving the birds should be thrown over the front of the basket or cage in which the birds are dried. This will not only watrm and dry them whilst the operation is being conducted, but will also be useful in preventing the fire from scorching the birds should it be a bit too fierce, and will also prevent any draught from getting at the birds whilst they are drying.

\section{ALI READY.}

Everything being in readiness, some cold water should be placed in each of the three basins, and slightly tinged with a little extract from the blue-bag. Then add sufficient hot water to the first basin, so that you can comfortably bear your hand in it. If the water is at all hard, a small piece of washing soda or borax may be added to the vater in all three basins, but if you are living in a district served by either of the big northern manufacturing districts this is not needed, neither is it reouired if some nice clean rain water is being used. But in the South, where the water contains thirty degrees or more of hardness than it does in the North, some artificial means of softening must be used. If you 'n not like to use soda or borax, use glvcerine. I, myself, prefer the glvcerine; it comes more expensive than soda or borax, but that is nothing when one has to consider the importance of turning the birds out well. Soda and borax are all right for white plumaged birds. but they are apt to make the colour run in such delicate 
plumaged birds as yellows, creams, silvers, duns, mealies, and blues. Further, whilst most excellent as softeners of hard water, they lack the power of making the plunage glossy, which is possessed by the ylycerine.

The process of washing withdraws from the plumage much of its natural oil, and it is a day or two before this gets restored, and if no glycerine is used the plumage dries harsh, hard, and lifeless looking. Some fanciers only use the glycerine in the rinsing waters. I used to do so myself, but experience teaches, and now whenever I wash any birds I use glycerine in all three waters. The quantity of glycerine should be a good teaspoonful to each quart of water. The water in the second and third basins should be each slightly cooler than the other. That is, the first rinsing water must not be so hot as the water in which the washing is performed, whilst the second rinsing water should be cooler still; in fact, only just about lukewarm, or, as they say in the North, "nicely aired."

\section{AN IMPORTANT FACTOR.}

One most important factor in the successful washing of Pigeons, or, for the matter of that, any other bird, is not to allow the plumage to come into direct contact with the soap if it can possibly be aroided. Therefore, before taking the first bird out of the basket in which it has been brought in from the loft, make a good lather of suds in the first bowl, using the nail brush and soap for this purpose.

The suds having been prepared, you will now be realdy to commence the operation proper. Take the bird from the basket and hold it in your left hand, with its head towards you. Immerse it bodily in the cuds, leaving only its head exposed. Hold it thus for a moment or two to let the water thoroughly saturate and soften the plumage. Then take the bird's left wing in your right hand, and work it to and fro in the suds, so as to loosen the dirt by the action of the water; transfer the bird to your right hand, and work the other wing about with your left hand. A 


\section{The IVashing of Pigeons.}

good Pigeon "asher needs to be ambi-dextrous. Next hold the bird firmly across the shoulders and work the tail to and fro in the same manner as you hate previously worked the wings about. By this time the suds will have thoroughly impregnated the whole of the plumage and you may commence to use the sponge The feather having become thoroughly saturated and softened by the water, there is little likelihood of its being broken by the rubbing. Rub backwards and forwards, upwards and downwards, in fact, in any and every way you like, but don't rub too hard, and not with a dry sponge; let the sponge be full of suds the whole time. It is not the hardness or vigorousness of the rubbing which gets the dirt out so much as it is getting the suds well into every fibre of the feather, so as to thoroughly loosen the dirt. I he dirt, it must be remembered, is, after all, on the top of the feather, not inside it.

Commence by spreading the right wing over the fingers of your left hand, whilst still grasping the bird with the thumb and the palm of the hand. It may be a bit awkward to do this at first, but persevere, and you will succeed; the knack of doing it will come. Give the wings each a good sponging, then turn the hird over on its back and well sponge the under parts of its body, the wings, and the tail. Returning the bird once more to the normal manner of grasping it, you should work the sponge well down its back, cushion, and tail.

\section{DO HEAD AND NECK NEXT.}

Next turn your attention to the head and neck. These should always be left till the last, so as to aroid putting the bird to unnecessary discomfort and inconvenience. The good fancier is merciful to his beast, and mindful of his own. Great care will be needed in washing the head and neck. The dirt seems to adhere more firmly to the head feathers than it does to any other part of the bird. This, to some extent, is due to the fact that there is always a certain amount of mucus being exuded from the mouth and nostrils, and this mixing with any floating dust 


\section{PIgEON'S AND AlL ABOUT Their.}

and dirt which may be about, and with particles of food, forms a thin coating almost like glue round about the face and head.

In washing the head care is needed to keep the soap out of the eyes. The eyes of some Pigeons are very sensitive. I have known a bird to lose its sight for several days, and for its eyes to be very highly intlamed, owing to particles of soap getting into them during the wash. A little of the suds getting into the eyes will not hurt, and beyond a temporary smarting the bird will not suffer, but the soap should be used sparingly about the eyes, as should too much be used very serious harm may result. An easy method of loosening the dirt round the face is to rub the feather well with the forefinger instead of the sponge, as by so doing the suds and sponge are kept away from the eyes of the bird. If the wings and tail are very dirty they should be spread on the table and well rubbed with the sponge.

\section{CLEARING OUT' THE SOAP.}

This about completes the lathering process, and the next thought is how to get the soapy suds out of the feathers again. To do his, hold the bird firmly between both hands and move it swiftly to and fro in the water in the first basin, so as to clear the wings and tail, then with a clean piece of sponge go well over the body, sousing it completely with the clean water; repeat the process in the third basin, and not much soan will have been left behind. Don't be afraid to use plenty of water. Give the bird a thorough good sousing, for unless you get every particle of soap out of the web of the feather all your labour will have been in vain, and the last state of your bird will be worse than the first. Should any soap be left in the feathers the bird will present a very rough appearance when dry, as the soap will prevent the feathers from webbing, and they will look liarsh and cottony in appearance.

The rinsing having been finished, draw the wing and tail smatly through the hands-this will extract much of the water from the feathers. Then well mop the hody with a dry sponge. Next take one of the 


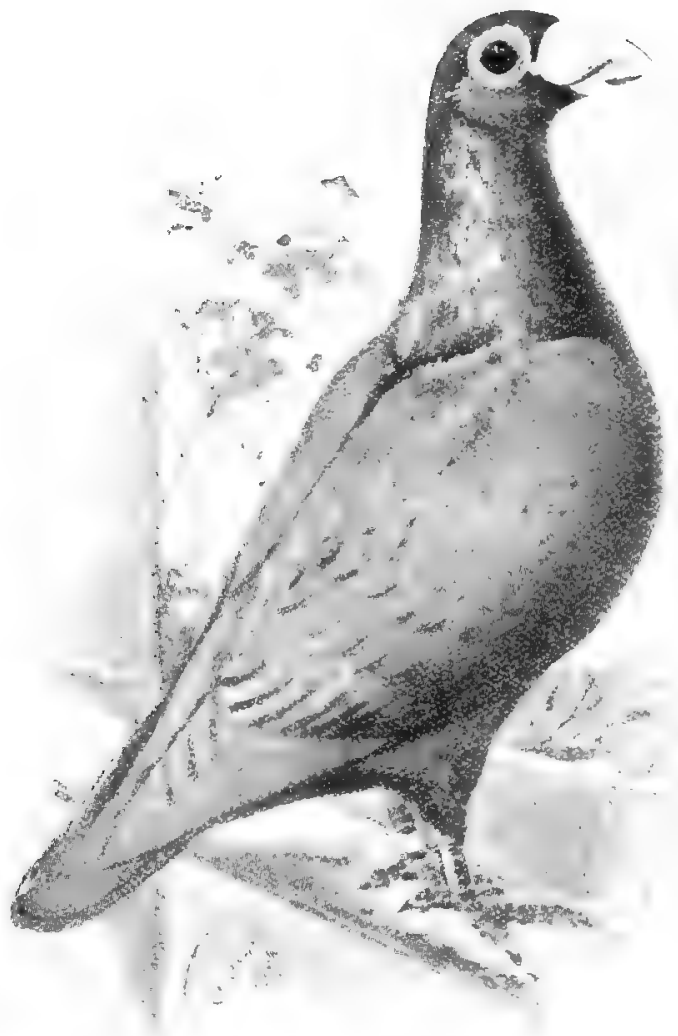

Adult Yellow Dragoon Cock.

Winner of very many prizes at the leading shows.

Bred and Exhibited by Mr. W. Bastard. 

warm dry cloths from off the front of the drying basket, roll the bird in it, and wipe your hands in one of the others. Having done this, throw one end of the cloth over your left hand, place the bird in it, with your fingers and thumb underneath the wings, take the other end of the cloth in the right hand and proceed to carefully and softly dry up what water is left in the feathers of the back, wings, and tail. At the same time you should so manipulate the left hand that all the water in the under portion of the body is extracted. Then straighten the feathers of the wings and tail by drawing them separately through the fingers of the right hand.

Hold the bird carefully and very firmly by the thighs, letting the legs fall between the first and second fingers of the right hand. This will cause the bird to flutter its wings about, which will assist in the webbing process. The tail may also be aided in this direction by holding the bird firmly in both hands and waving it to and fro for a moment or two. It must be remembered that the whole of the washing process must be conducted as closely to the fire as possible, so as to avoid any risk of chill or cold being contracted. To allow a bird to get cold when its plumage is wet, and after it has recently been in warm water, and all the pores of its skin opened, would be courting disaster swift and sure.

\section{HOW BIRDS STAND THE BATH.}

Naturally, some birds stand the process of washing better than others, owing to being possessed of either a stronger and more muscular body, or else a less highly sensitive nervous organisation. With some there is little, if any, enervating result, but on some of the weaker ones it has a somewhat exhausting effect. I have before now seen some extra nervous birds absolutely prostrate after the operation, but only once have I known one to die; that was when some patent special Pigeon wash was being tried, and the bird died not from exhaustion induced by the washing, but by suffocation from the fumes arising from the potent, as well as patent, Pigeon wash. 
Fatal results are indeed few and far between so far as washing is concerned. A bird should come out of the wash looking none the worse for the experience, and be able to walk round the drying basket and commence shaking and preening itself directly. Should it happen that a bird does come out of the wash looking rather weak, helpless, and prostrate, don't be alarmed. I have seen some of the nerrous ones look as though they were approaching their end when they have first been put in the drying basket, but after they have lain helpless for a few moments they have pulled themselves together and got (1) their legs:

\section{FATALITIES SELDON OCCUR.}

As I have said, fatal results seldom occur, and when they do it is not because of the washing, but senerally becaluse the bird hat been held too tightly in the hand and has not been able to breathe properly. There is a wonderful difference in birds. Some will struggle tremendously the whole time, not only whilst in the water, but even whilst being dried in the towels; others are very passive, and give little trouble. should, however, a bird struggle and you feel it is guing to clude vour grasp, let it do so. Don't on any account attempt to tighten your hold on it, because if you do you may possibly nip it too tight and stop the circulation of its heart, or you may only half grasp it and pull a lot of feather's out. Therefore, if it plunges and struggles, let it go; you can very easily pick it up again.

If the bird is held firmly in the manner I have previously described, it will not be able to struggle much. The first and greatest consideration in the washing of Pigeons is plenty of self-confidence on the part of the operator, and when such is wanting the Pigeons seem, by some intuitive instinct, to recognise the fact, and, like wilful children with a weak parent, they act accordingly. A strong, firm, yet tender grasp is what is required, and when this is present the birds, as a rule, are as quiet and docile as lambs. There is a great att in handling birds properly, and an experienced and skilful washerman feels quite as 
much at home in putting his little pets through the suds as he does in taking his own early morning: sponge. The birds know and appreciate the difference between the two forms of handling.

The birds must not be allowed to get too dry in the drying cage, and after being close to the fire for some time, say twenty minutes or half-an-hour, they should be moved a little further back. In about one hour from the time when they were put into the drying cage, or basket, they may be taken out and placed in some clean pens, which have been fixed up previously, either on the kitchen table or dresser. It takes from eight to twelve minutes to wash a Pigeon, sponge and wipe it, and place it in the drying cage, and it takes fifty or sixty for it to dry thoroughly.

During the time the birds are in the basket they should be taken out occasionally, grasped firmly by the thighs, and allowed to flap their wings about a bit. This loosens the body feather, and helps forward the drying process by letting the air get into the feather. It also assists in the webbing up again of the flights and tail.

Once a bird has been washed it must be remembered that it quickly soils. Therefore, all pens into which newly washed birds are put should be scrupulously clean, or the washing will have been of little effect; in fact, will have been in vain. Birds with soiled plumage are severely handicapped in the race for supremacy, so keen is the competition nowadays, and it takes very little to turn the scale one way or the other.

\section{THE VALUE OF SPRAYING.}

When the birds are nearly feathered up, say two hours after the wash, or perhaps three, it will be beneficial to spray them lightly with a little water and glycerine, the two being mixed in proportion of a teaspoonful of glycerine to a pint of water. This spraying assists in the tightening up of the feather, and also in the putting on of a soft glossy appearance.

It is generally thought that white birds are the only ones improved by a wash, but this is a very mis- 
taken idea. Trhites, it is true, are considerably improved in appearance by being washed, and so are most of the coloured varieties if they are kept in a town. The dirt is not so easily seen on a coloured Pigeon as on a white one, but it is there all the same, and when it is removed there is a corresponding improvement. In washing delicate colours like silvers, yellows, creams, and reds, great care is needed; the soapy water must not be allowed to hang about the plumage longer than is absolutely necessary, or it maly make the colour run. I have myself washed birds of all colours. It is a great thing to be an expert laundryman, as a good tubbing will improve a secondrater very considerably, whilst on the other hand, a bad wash will destroy all chance of winning possessed by the greatest champion ever bred.

Another point to be considered is the difference in the quality of feather in birds, and whilst washing improves some feathers it will ruin others. Some birds it would never do to wash, but a rub with a dry silk handkerchief will work wonders upon them. In this connection I am, of course, referring entirely to self coloured birds, such as blacks, reds, duns, silvers, and yellows. Others, again, are considerably beatified by being rubbed over with a sponge which has been dipped in spirits of wine, the sponging being followed by the silk handkerchief. I cannot convey to $\mathrm{my}$ readers how to discriminate between the feathering of birds which should be washed and those which should not. No man on earth could do it. The power can only be obtained by practical experience and observation. One thing I can, and do, say, speaking in a general way, the bird which best repays the washerman for his trouble is a rich, lustrous coloured black. 


\section{CHAPTER X. \\ THE BREEDS OF PIGEONS.}

In previous chapters I have dealt with housing, breeding, feeding, moulting, and other details of general management; in a word, what has gone before may be termed the practical portion of $\mathrm{my}$ work. These latter chapter's may be styled the descriptive, as in them I purpose giving a brief description, not of all breeds of Pigeons, as my space will not allow of that, but of those varieties which are most highly esteemed, and most generally kept by fanciers of the twentieth century. This being so, I naturally commence with the King of Pigeons.

\section{THE CARRIER.}

This handsome bird has for long enjoyed pride of place in the Columbophile Kingdom, and although to-day it has not so great a popularity as in days of yore, yet none would be so bold as to dispute its position as the King of Pigeons. A well-grown, properly developed Carrier is, indeed, a most handsome Pigeon. Towards the end of the nineteenth century a great craze set in for extreme and inordinately sized wattles, and in the rush for this property, shape and carriage (two most essential properties), were somewhat neglected. The Carrier is a large, upstanding bird, of most majestic appearance, and size is an important feature. A weak, puny, undersized bird, however good in head properties, will never go far on the show bench. Size and length are of great value. Length of face, length of neck, length of body, length of feather, and length of leg are properties keenly sought for, and highly appreciated when seen. From the tip of the beak to the end of its tail a representative male member of the family should measure at least isin. Hens, naturally, 
will be somewhat shorter, even as they are also lighter in build than the cocks. Important as they are, size of wattle and substance of beak are not everything in a Carrier. Shape and carriage are equally valuable, and without them a bird is not a true Carrier, for style and that indefinable something known as quality give an air of distinction to a bird which nothing else confers.

The beak should be long, stout, straight, and very close fitting from tip to base. Length of face is a great feature, and this is measured from the tip of the beak to the centre of the eye, and should be from $2 \mathrm{in}$. to $2 \frac{1}{2} \mathrm{in}$. The colour of the beak should be white, or light, very light, brown colour. A beak which curves or bends downward is a grave fault.

The beak wattle is a source of much concern to breeders, as so much depends upon it. As it is a property which is years in arriving at maturity, it affords endless scope for the exercise of that great virtue, patience, and also of continual care and attention. A fully developed wattle, as seen on a Pigeon of two to three years of age, should present a close, even appearance. It should not be.rough in texture nor lop-sided, but should, when viewed from the front, appear even and regular, not only in formation, but also in balance. That is, it should present an appearance something similar to the shell of a walnut, both in shape and surface. A "walnut wattle", is much esteemed. The greater portion of the wattle is on the upper mandible; that on the lower is known as the jewing or jew wattle.

The eye wattle, or ceres, should be large, round in shape, fine in texture, fit close to the skull, and be formed in proportion to the size and length of the skull. A good cere must not be hard, neither must it be soft and flabby. It must be affixed to the face, and not grow over the skull, neither must it grow too much forward so as to crowd the face, and give the bird the appearance of being short in face. It should be perfectly round, and about rin. in diameter. The favourite torm for a perfect eye wattle is "roseeyed." The skull itself should be long, fine, narrow 


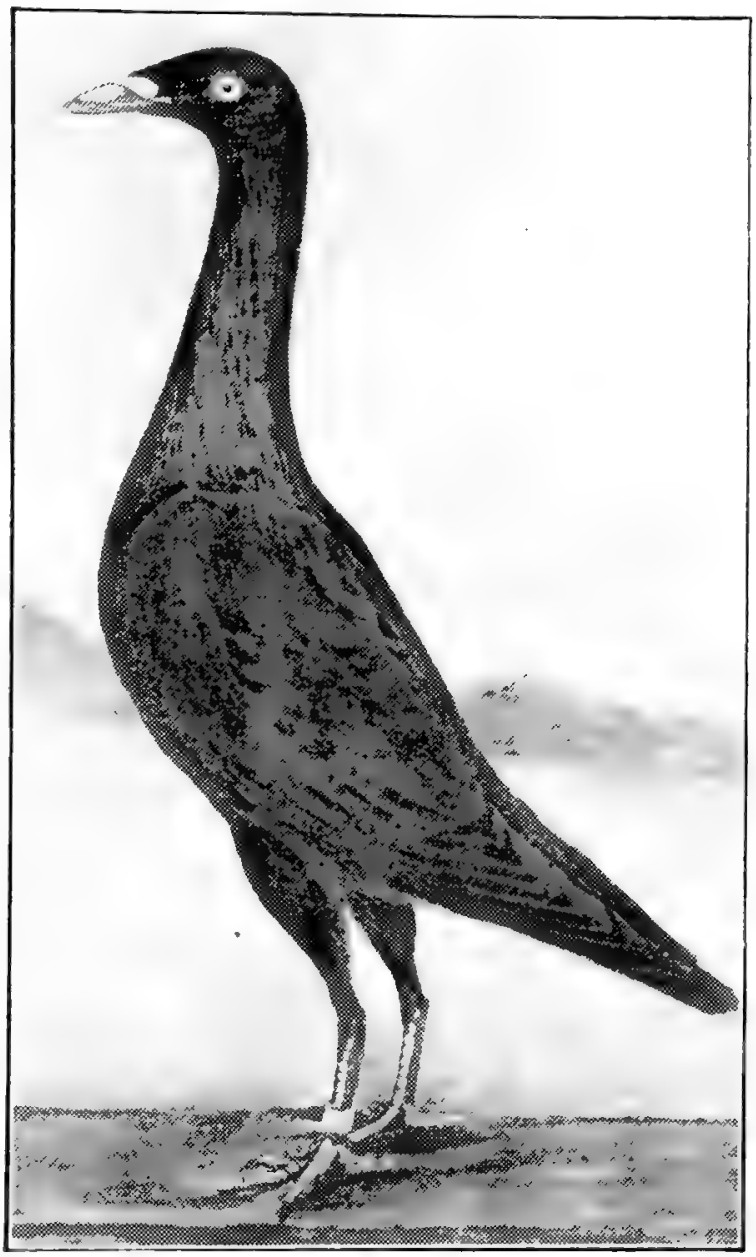

LFrom a Drauing by Miss D. J. Williams. our Newest Breed.

"Martian," a typical Yellow Martham hen, winner of lst Manchester, ete.

Bred and Exhibited by Messrs. Bracey and Cooke. 

and fat. The eye should be large, full, and prominent, and possess a staring appearance.

The neck should be long, thin, and tapering, and set on a stout, broad-set pair of shoulders. The butts of the wings should project beyond the chest, and the back should be flat; a rounded back is a great fault. The wings and tail should be well braced, and show no clumsiness or slovenliness. The legs should be stout, long, and set well apart, so as to give the bird a commanding and alert appearance.

The chief colours are black, dun, and white, followed by blue, silver, red, and pied.

\section{THE BARB.}

To the Barb belongs the distinction of being the only Pigeon mentioned by the great dramatist, Shakespeare. It is everywhere regarded as a Pigeon with very ancient lineage, and is much esteemed by breeders on the Continent and in America, although it has, to a great extent, lost its hold on the affections of English breeders.

Most of the show properties of the Barb are centred in its skull. The beak should be short, thick and massive, and slightly curred, and in colour should be white, although many good birds have dark or "stained" beaks. The beak wattle should be fine, close, and even in texture, divided in the centre, and have the appearance of two beans, one on either side of the division. The eye should be pearl or white, but it is seldom found without a tinge of yellow; but a white eye, in addition to being the correct thing, has the advantage of setting off the glories of the eye wattle, which is one of the chief, if not absolutely the chief, characteristic of the Barb. A faulty cere, either in formation or colour, is a big defect. In colour it should be a rich, bright, fresh-looking red, and in formation it should be circular and as large as possible. It must be firm, yet not hard, soft, yet not flabby; it must stand well away from skull, and be of considerable thickness. The skull itself should be broad, somewhat flat on top, but with a good full frontal, and a gradual rounding away into the neck at 


\section{5t Pigenons and Ali, About Their.}

the base. Viewed from the front, the head of a highclass Barb should present the appearance somewhat of a cotton reel.

The neck should be fine and short, a long reachy neck being a great fault. It must be nicely modelled and show no gullet. 'The chest should be broad and full, the body rather long in proportion to the neck; the wings should follow the body in length and be neatly carried. The legs, like the neck, should be short, of just sufficient length to carry the body gracefully without making the bird look squatty or gawky.

The colours are black, red, yellow, dun, and white, running in this order of popularity. This is due in great measure to the fact that the blacks and reds excel in head points, although of late some extremely stout skulled yellows have been bred.

In the breeding of Barbs, as in Carriers, there is considerable mixing of the colours, blacks being paired to almost all the other colours, and, as a consequence, many grand birds are bred which are of indifferent colour. Whilst the breed is in few hands, and head properties are esteemed before anything else, this I suppose will continue, but did some enterprisino fancier strike out on his own, determined to improve the colour of his Barbs, whilst not losing head points, he would soon reap a rich reward.

\section{THE DRAGOUN.}

Of all wattled Pigeons, the Dragoon is the most popular and most largely kept. The reason for this popularity doubtless is because it is a bird in which there are many points of importance, and undue value is not placed upon any. Thus, although a wattled Pigeon, and a Pigeon in which the wattle is of considerable importance, yet the wattle is not everything, and is not allowed to over-balance the other properties of beak, eye, cere, skull, bodv, feather, colour, and carriage, all of which carry weight in the make-up of the twentieth century Dragoon. The Dragoon holds somerwat the same position in the 
Pigeon liancy to that of the game cock in the poultry world, or the fox terrier in dogdom.

Dealing with the Dragoon in the same manner as I have the Carrier and Barb, I commence with the beak. This should be stout, of moderate length, straight, with the mandibles fitting closely and evenly without any openness. Blues, chequers, and grizzles should have dark beaks; silvers, dark horn colour; reds, vellows and whites, flesh colour. The beak wattle should be shaped something like a peg-top split in halves, hence the term "peg-shaped wattle "; that is, broader and higher at the back than the front. It should be evenly distributed, without lumps or corruscations, and be fine in texture. The skull, like the wattle, should be wedge-shaped, wider behind than in front, and slightly oval on top, viewed either from behind or in front, a flat or shallow skulled bird being of little worth.

The eye should be a rich, ruby red in all colours except whites, full and bold, and present an alert, watchful appearance. Blues, chequers, and grizzles are the best in eye colour at the present time, the silvers, yellows, and reds not coming up to the ideal, being mostly red or gravel-eyed. TVhites should have a "bull," or dark hazel eye. The eye cere should be fine in texture, thin in substance, nearly circular in shape, and somewhat pinched at the back edging. Blues, chequers, grizzles and silvers should have a dark, or damson coloured cere, with a nice powdery bloom like unto that of the Hamburgh grape. In reds, yellows, and whites, the ceres are flesh coloured, and should possess the same bloom.

The neck should be short and thick, the breast broad and prominent, the back flat, shoulders broad and well defined, the wings strong, stout quilled, closely braced and carried well above the tail; the tail should, like the flights, be short, compactly made, and rell carried; a long feathered Dragoon lacks that grace which is so much desired. The legs should be short, set well apart, with stout, muscular thighs. The shape generally should be cobby and compact, and the carriage alert, smart, commanding and graceful. 
Dragoons are a large and varied family, embracing in colour-blues, blue chequers, red chequers, silvers, silver chequers, grizzles, reds, yellows, whites, and mealies. In breeding blues must be matched to blues, chequers to chequers, silvers to silvers or blues, grizzles to blues, reds to reds or yellows, yellows to yellows or reds.

\section{THE ANTWERP.}

This variety, at one time very largely bred in the West Riding of Yorkshire, Lancashire, and the Birmingham district, has of late fallen somewhat from its former high estate, and although there is a club devoted to its interests, the breed does not possess the rim and go which its qualities demand and deserve. There is nothing showy or flashy about the Antwerp, no meretricious charms belong to it, but rather is it the embodiment of all that denotes strength, tenacity, and pugnacity; it is, indeed, the bulldog of the Pigeon Fancy. Its properties are chiefly those of the head, very little attention being paid to colour, etc., and in its skull are to be seen some of the most wondertul developments of the breeder's art; developments which have concentrated themselves to such an extent that, unlike other breeds which are subdivided by colour, the Antwerp is sub-divided into short-faced, medium-faced, and long-faced, according to the length of skull. The length of the face is measured from the centre of the eve to the end of the beak, and a short-face should be $i_{4}^{3}$ inches, a medium about $\mathrm{I} \frac{5}{8}$ inches, and a long-face anything abore $\mathrm{I} \frac{3}{4}$ inches.

The beak of the Antwerp should be rery stout, especially in the lower mandible; it should also be proportionately short, varving, of course, in the different lengthed faces. The beak wattle should be broad and compact, eren in texture, and fit closely to the frontal, not being loose or lop-sided. The eve wattle should be hard, firm, and circular, without softness or coarseness. The eve should be full and bold, and of a gravel or orange shade. The head should, in all three dirisions of the family, be very broad and full, well archeo and free from bumps or 


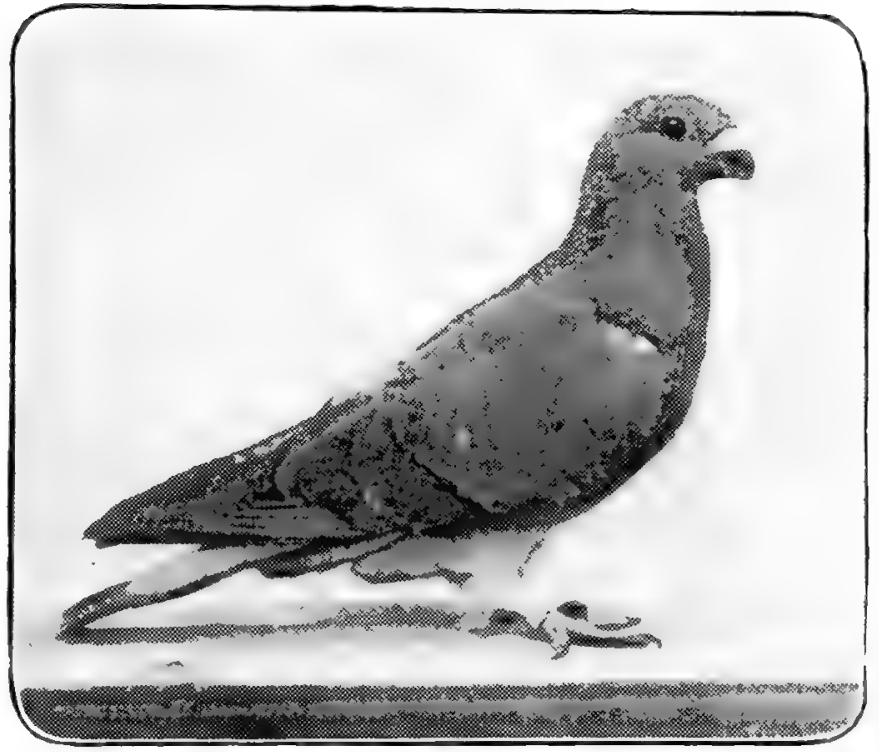

1919 Black Chequer Antwerp Hen.

Winner of 1st Cliff, 2nd Settle. 1st and spl. Altrincham, and 1st Dairy

Bred and Exhibited by Mr. A. T. Mays. 

angularities. The neck should be short and stout, the shoulders very broad and massive, with a bold, round chest. The back, although not flat, should not be too rounded. The wings should have great strength, both of quill and web, and should be carried well up. The legs should be strong and muscular. In size the Antwerp should be larece yet not ungainly or Runtish in appearance.

The sub-varieties are differentiated as follows:The short-faced should be, as its name implies, short in beak and short in skull, yet it must be very broad and full in skult, and when viewed in profile the skull of the shortace should resemble the shape of a penny piece. Few, indeed, come up to this ideal, the prevailing fault being lack of rotundity; but the shortfaced Antwerp, like the English Owl, wants a round head, with the eye centrally placed. The beak and head of the medium-face should be longer than that of the short-face, but there should be the same fullness, width and strength of muzzle, the difference being that whereas the short-face should be round, the medium-face is so elongated in face and back skull as to make the head appear oval in shape. The long-face presents greater length of face and sweep of skull than the medium-face, and there is a corresponding increase of stoutness and length of beak, and quantity of beak wattle.

The shape of body and carriage should be the same in all three divisions, and it should never be allowed to become clumsy and slovenly. Breeders have given so much attention to substance of head and beak that they have somewhat neglected colour, shape, and carriage of body, and neatness of feather. If attention is given to these points, whilst preserving the massiveness of head and beak, especially of the under mandible, the Antwerp should again become much prized and sought after.

The colours mostly seen are silver duns and red chequers. There are blues and blue chequers, but they are seldom seen, and when seen are far behind the other colours in substance of head and beak. TThen 
all is said and done, the simple fact remains that head and beak are the great points of the Antwerp.

\section{THE SHOIN HOMER.}

This is undoubtedly a most popular and largelykept variety. North, away in distant Scotland; South. as far as the Isle of Wright; West, in Cornwall and W'ales; and East, in Lincolnshire and Norfolk. In fact, the show Homer is ubiquitous, and the difficulty would be to say where it is not popular. The number of its followers is everywhere increasing, and year by year nore birds change hands at big prices than in any other variety. So big have been the prices realised for Show Homers that they have provided, year after year, the sensation of the season.

In recent years much progress has been made in the perfecting of the breed, and to-day we can, at any show of importance, find a large number of birds combining in the highest degree the much-valued properties of substance and quality. The rage for substance of head and beak which prevailed so strongly years ago has worked itself out, and breeders both North and South have set thumselves to produce specimens excelling in all-round properties. Further, there is not now the difference existing between the birds of the North and the South. Breeders of the North have bred down to. quality, and those of the South have bred up to substance. To-day the show Homer is one of the most handsome, graceful, and commandiug firds on thi show bench.

'The beak is an important property in the Show Homer, because upon its length, stuutness, and setting, depend in great measure the perfection of the profile. The beak should be long, but not unduly stout; it numst not overbalance the rest of the face, or the bird will appear mean-faced. From the corner of the eyce to the tip of the beak should be from I $\frac{1}{2} i n$. to I $\frac{3}{4}$ inl., with proportionate stontness. The beak wattle should be very fine and glovelike in texture and fit, and be $\mathrm{V}$-shaped.

The eye should be bold and prominent, and pearl or white in colour. A red eve is a bad fault, 
and one not easily bred out of a strain. Purity of eye is the hail-mark of a high-class show Homer. The cere should be very fine and hard in texture, small and close fitting, and of dark a colour as possible. A milk-white eye in a rich dark cere gives a bird a most distinguished and handsome appearance.

The head, when viewed in profile, should show an unbroken curve from the tip of the beak to the back of the skull. The face should be well filled in, without bumps or angles of any kind.

The throat must be clean and neat, without suspicion of gullet.

The neck should be of such proportionate length as not to destroy that graceful poise of head which is such a great feature in the Show Homer. At the shoulders it shoult be stout, and taper away gracefully as it approaches the head.

The body shotild be short and wedge-sliaped, broad in the chest, and tapering well away at the vent. The shoulders should be strong and stand out somewhat from the chest. The beak should be broad, flat and straight.

The flights sho:ild be short, stout in web and quili, close fitting, and carried well over the tail.

The body feather must be short, hard, and close fitting. Softness or slackiness of feather is out of keeping with the characteristics of the Show Homer.

The tail should be short, compact, and carried clear of the pen floor.

The legs should be stout and of mediun length, with strong, well set thighs, and nicely proportioned in length from body to hock, and hock to feet, which also should be strong and cleanly made.

Much has been said and written about the size of Show Homers. A big, coarse Runtish body is as wrong as a small nreedy one. The Show Homer is a bold, commanding bird, and therefore should possess a medium-sized body. One showing strength with giace, and no clumsiness. Then in show position the bird should possess an alert yet dignified appearance, and this it cannot do with an ungainly sized body. 


\section{Pigeons and Ali About Their.}

The principal colours are Black-chequers, Bluechequers, Silver-chequers, Reds, Red-chequers, Blues, Silvers, Mealics, Yellow-chequers, Yellows, in something like the order given.

Between the Black-chequers and Blue-chequers there is very little difference, and it is often difficult to say if a bird is one or the other. This is due to the fact that brceders trouble little about the colour and marking of birds they pair up. Head, eye, and cere are given all the thoight, at the expense of other valuable properties.

The Silver-chenters are seldom very pure in their grotund colour, and there is room here for the exercise of the breeder's energy and ability. The production of a real silver strain of Silvor-chequers, with all the other properties in perfection, would well repay any breeder who set himself the task.

\section{THE EXHIBITION FLYING HOMER.}

'This, one of our modern brecds, is very popular, and has its devotees in all parts of the country. The breed has a strong and flourishing specialist club to looli after its interests, and its standard of perfection has been so drawn as to exclude birds showing Show Homer tendencies in head, whilst being a highly refined edition of the same in body. High as the ideal of the standard is, it is astonishing how close to it breeders have attained in a few years.

There is a tendency at the present moment to encourage sizc, which should be checked, because, if allowed to continue, the breed will lose that smart, alert, active appearance which is one of its greatest charms. With this increase in size of body has come another failing, or rather objoctionable feature, a curving of the face, which has undoubtedly been borrowed from the Show Homer. This is altogether opposed to the standard, which distinctly states there should be no such sweep of sliull, but a nice straight face, with an imperceptible rise from the beak to the crown. Judges and breeders both should see to it that the craze for sizc and fulness of face is not allowed to spoil one of the most attractive breeds we possess. 


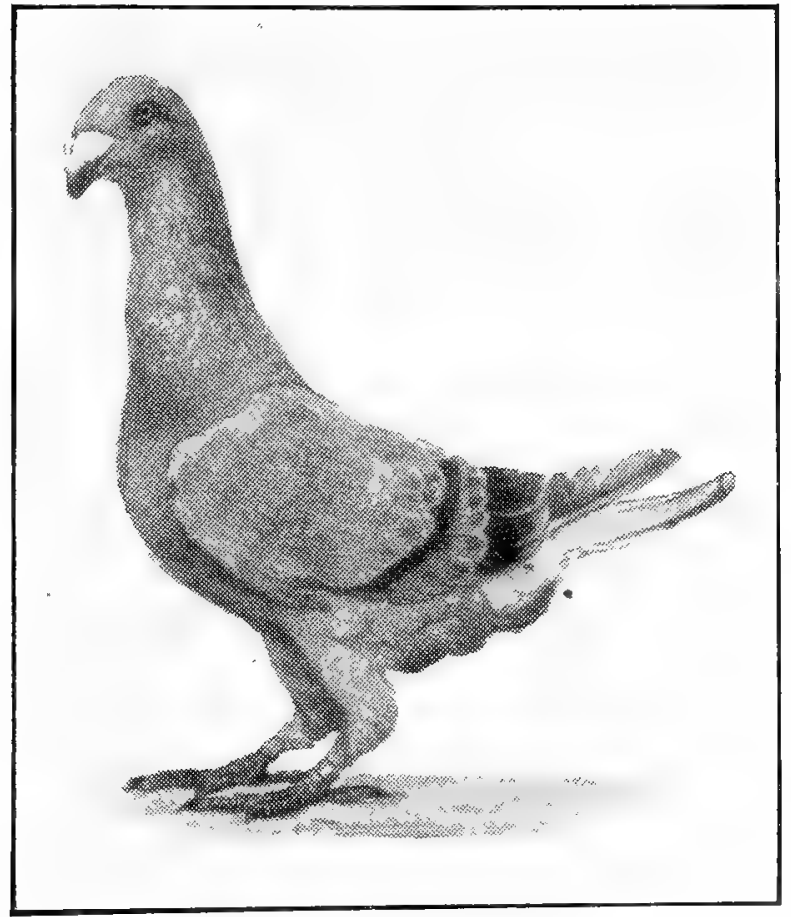

1919 Strawberry Mealy Show Homer Cock.

A bijd of beautiful type and quality.

Bred by Mr. Fred G. Barnard.

whose strain has helped to produce many of Fingland's classic winners. 

Another point to be remembered is that length of beak is not the same thing as length of face; the two do in many instances go together, but there are birds with only ordinary or modarate length of face and skul, but which possess long spindley beaks. Some, in their ignorance, speak of these birds as being long in face. They are not. They simply possess abnormally long beaks, and such birds do not show that gentle rise from the beak to the top of the skull.

A very important point in the Exhibition Flying Homer is the eye. I am not referring altogether to to its colour, but more particularly to its shape and size. It must be full and bold, very bright and clear, so as to give the alert appearance needed, and be in due proportion to the size of the head. Some eyes are very large, but they are not bold; they are more or less sunken. Such an eye, no matter how good in colour, spoils an otherwise good bird. A nicely shaped, round bold eye of a pearl or white colour, set in a fine, dark cere, adds immensely to the attractions of a bird.

A tip-top Exhibition Flying Homer should bear some close resemblance to the following standard, which has been compiled by the Exhibition Flying Homer Society :

BEAK.-Fairly stout and straight set, both mandibles of nearly equal substance, close fitting, a hard dark colour preferred. In pieds, a particoloured beak is admissible.

WATTLE.-Small and smooth in texture, free from coarseness, and V-shaped.

EYE.-To be pearl colour, bold, alert, and full of intelligence.

CERE.-Small, hard, and finely laced, lark colour preferred. In pieds, a parti-coloured cere is admissible.

The HEAD in profile, rising gradually and a1most imperceptibly from wattle to above the eye, showing no angularity or flatness, the whole giving the appearance of a nice straight-faced bird, wit? 


\section{I66 Pigeons and Ali About Them.}

nothing of the character and swcep of nead of the Show Homer, immediately above the eye being the highest point, then descending to the neck without exhibiting a broken outline. The top view sinould show fairly broad hetween the eyes, gradually narrowing towards the wattle. The crown should be convex from eye to eye, and the whole hea 1 and beak should have a long appearance, with no suspicion of weakness.

NECK.-Of medium length and thicknes;, e1tirely free from gullet, and gradually widening from head to body.

CHEST.-Broad and full.

BACK.-Short, flat, broad across the shoulders tapering off to the rump and tail.

BODY.-Deep in keel, short and straight in breastbone, plenty of front, and finisning in a redge shape.

WINGS.-To have powerful and pruminent butts, the flights being fairly short, st:ong, broari, and closely overlapped.

TAIL.-Close fitting, having the apporance of one feather, carried clear off the grome, somewhat short in proportion to the size of the lind, and $6 x$ tending slightly beyond the flights.

LEGS.-Of medium length, good muscular thighs, and well set back.

CARRIAGE.-Erect and bold.

SIZE.-Medium, every point in proportion.

COLOLR.- Sound, bright and hard, in chequers the chepuering to be bold and distinct, not having a waslied-out appearance.

CONDITION.--Clea1n, hard, muscular, and plump, but not fat.

GENERAI CONFIGURATION. - Short in body, broad shoulders, deep keel, presenting a wedge-shaped appuarance, medium in size, and excossive in no property, hard, and very close feathered, alert and watchful. 
Scale of value of each point, total roo.-Head, I5; beak, 2 ; wattle, 2 ; eye, 5 ; cere, 5 ; neck, 5 ; chest, 5 ; back. 5 ; body, 5 ; wings and flights, I5; tail, 4 ; carriage, 5 ; size, 5 ; colour, 5 ; condition, I5 ; legs, 2 .

The colours most generally shown, are Reds, Red Chequers, Mealies, Blues, Blue Chequers, Blacks, Black Chequers, and Pieds.

THE WOREING OR RACING HONER.

The sport of Pigeion Flying has made tremendous strides during the last few years, and to-day there must be at least 34,000 to 40,000 people interested in the sport in the United Kingdom alone. The National Homing Union has a membership of more than half that of the figures given, and it is only fair to assume that where at least there is one fancier who is a member of that organisation, there is another who is not.

The sport of Pigeon racing is most absorbing, enthralling, and exciting, even whilst it is one of the most honest and best conducted of sports. In Pigeon racing, every bird is his own jockey, and thus there is little opportunity for mal-practices. The amount of monev which is flown for each year runs into hundreds of thousands of pounds, and if statistics could be compiled I have no doubt that we should find that quite $£ 500,000$ is flown for each year in the United Kingdom. On the continent the total amount would perhaps not amount to so much in the aggregate, but the prizes are very valuable, owing to the system of pooling, which is more advanced than with us. In the best races in Belgium, it is not unusual for a bird to win from $f_{500}$ to $f_{\mathrm{I}, 000}$ in one race. The excitement occasioned by the National races extends from one end of the country to the other, and it is not at all unusual for the whole of a man's friencls to find the money to enter the crack of his loft in a number of the pools in the big races. The question as to how birds "home" has never yet been solved. Some argue that the birds fly by instinct, others say it is sight; others again persist that reasoning power is the faculty that brings birds 


\section{Pigeons and All About Them.}

home. Certain it is that sight alone cannot be the dominant faculty, because birds that have only been trained 200 miles in a given direction have been sent 500 and 600 miles, and "homed" successfully. I myself, on one accasion, jumped a bird from 200 to 400 miles, and he won a long way in front of the 501 other birds in the race; and again on one occasion, in a 6oo-milo race, one of my birds was jumped from 200 miles to 600 , and was 2nd in the race. Sight alone could not do this. My own opinion is that the only reasonable and natural explanation of the homing power is that the training through which the birds go develops some natural power which is inherited, and that the greatest factor of all is reasoning power. It must ever be remembered that unless a bird is trained it has not the power to home, but is like a rudder-less ship on the open sea-helpless.

In training, the birds are first of all allowed to view the surrounding country from the top of their loft, then after a few weeks' flying round the loft they are taken about half a mile from home and "tossed"; the next stage is a mile, then three, then five, from five to ten, ten to twenty, twenty to thirtyfive or forty, then seventy or seventy-five, the succeeding stages being I00, I50, 200, 300, 400, and after that any distance up to 600 or 700 miles. Races of 700 miles and over are not frequent, and are invariably productive of great losses. The speed at which a Homing Pigeon will travel is controlled by the state of the atmosphere. When it is bright and clear, with a fair amount of moisture in the air, and the wind favourable, birds will travel at any speed from I, 200 yards to a mile per minute; but when it is hot, with a dry atmosphere and not much wind, $\Upsilon, 000$ yards per minute is good work; again, when the weather is stormy, and the wind against them, anything from 600 to 900 yards per minute is good work. Birds which can fly for fourteen or sixteen hours and do 700 or 800 yards per yards per minute on a bad day are the most highly esteemed, because on such a day is brought out not only the bird's reasoning powers, but also its powers of endurance. 
In the selection of stock for breeding, good looks and such points as colour and marking have no place in the thoughts of a Working Homer fancier. Pedigree is the great thing which is studied, and as much as $f_{50}$ has been paid for birds from a good strain, and which have proved themselves also to be good fliers. Stock birds bred from noted birds have often been sold at $f_{5}$ to $f_{1}$ Io each. Apart from pedigree, the points valued, are boldness of eye, width of skull, with prominent frontal indicating brain power, strong muscular shoulders, stoutness of quill, width and strength of the web of the flights, so that the flights overlapping or covering each other well, the birds are able to ofier resistance to the air in the same manner that the blade of an oar offers resistance to the water. The chest should be deep, so as to afford plenty of room for the lungs to play. Width of chest is not greatly to be desired, that is, abnormal width, becausc a wide chested bird offers more resistance to the wind; a Racing Homer needs a chest deep like unto that of the greyhound. The tail should be of moderate length, strong and closely packed; a loose, slack tail is a hindrance to a bird when flying, and one that is too short does not give the bird that power to rest in the air which a well proportioned and stoutly made tail gives. Further, the tail acts as a rudder to the bird during flight, and thus will be seen at once the necessity for its being well and proportionately built.

\section{THE SCANDAROON.}

The Scandaroon is not very largely bred in this country. In Germany it has a host of admirers. It is the only one of the long-faced wattled Pigeons bred in England which has not a straight face. Its long arched beak and face, which is one of its stroingest points, is looked upon by many as being a malformation, and one has to be educated up to a certain standasd ere it is possible to appreciate the points which go to make up a good exhibition specimen of the variety. One great charm the Scandaroon possesses, and that is its marvellous depth, richness, 
and purity of colour. Red, Black, and Yellow Scandaroons are what their name implies, and could the same beautiful colouring be infused into many of the other brecds known to the English Fancy, their value and beauty would be considerably enhanced.

Scandaroons are rather quarrelsome and pugnacious, and he who would keep them must give them plenty of perch room. Box perches are the best for them, as by their use quarrelsome members of the stud can be kept from doing harm to other hirds unawares. In selecting stock for breeding, the chief points are length of face, height and fulness of arch, and stoutness of beak. Birds with straight faces, crooked or spindley bcaks, and flat faces and crowns, are of little worth.

The beak, which is so prominent a feature, should be very long, stout, well arched, closely fitting, blunt at the tip, and white in colour. The beak wattle should be fine and even in texture, long and full, not too flat, yet not rising so as to break the profile of the face. A coarse, wattle will completely spoil an otherwise good face.

The skull must be long and narrow, well arched from the beak to the crown, and free from angles or lumps. In fact, from the tip of the beak to the back of the skull should be an unbroken semi-circular clongated outline, whilst from side to side the skull should be round, any tendency to flatness taking away from the arched appearance.

The eye and eye cere, although not of great importance in themselves, have much to do with the general finish of the head. In Pieds and Whites the ere should be "bu11" or dark, in Reds and Blues rich hright red, and a paler red or orange in Yellows. The ceres should be in proportion to the size of skull and heak wattle, fit closely to the skull, and be of rich flesh colour bordering on red.

The neck should be very long, slender, and swan-like in curve, the chest wide and prominent; the back should be flat, the wings shonld be rather short, yet strong with the flights well folded, or packed; the tail, also, should be short. 


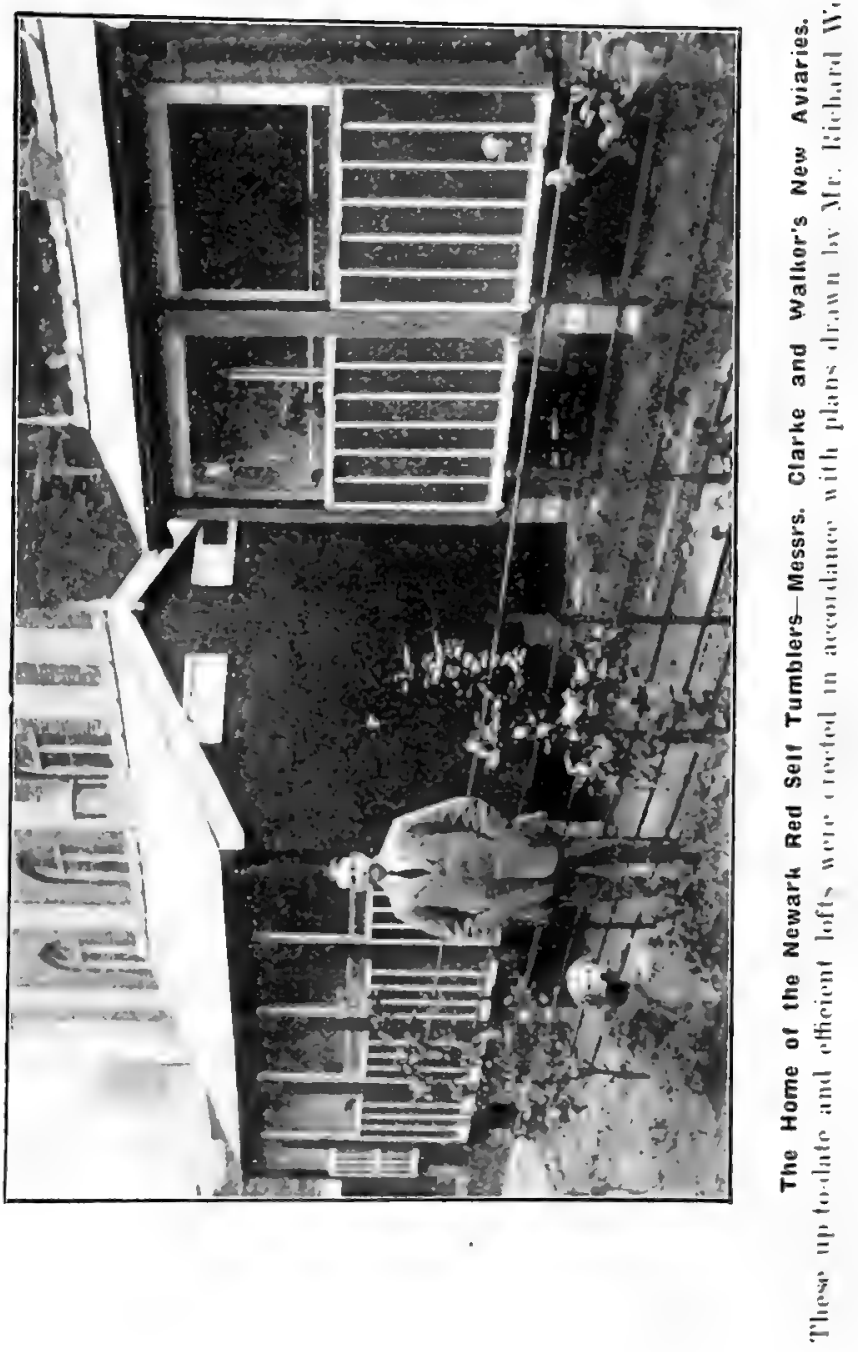



The legs should be long, stout, and muscular, with plenty of thigh, so as to hold the body well up when the bird is in position, as although a somewhat large bird, the Scandaroon is not a slovenly one.

The colours mostly seen are Reds, Blacks, Yellows, Whites, and Blues. The markings are similar to those of the Magpie, except that they run up into the neck, and that there are two almond-shaped spots below the eyes extending from the back of the beak to the ears.

THE RUNT.

The Runt is the largest Pigeon known to the English Fancy, and it is of the common or Dovehouse type. Its great features are size and length of feather. It is indeed a huge creature, measuring from the tip of its beak to the end of its tail some twenty-one or twenty-two inches, whilst in girth the body is often fourteen, fifteen, or even sixteen inches, whilst the length of feather is prodigious, the wings, when outstretched, measuring from a yard to forty inches. In carriage the Runt should be upright, but it has no chance of showing its style in the ordinary pens provided at English Pigeon shows. The colours most usually seen in England are Whites, Blues, and Silvers, but on the Continent I have seen some very beautiful Reds, and Yellows. Tightness and hardness of body feather is a valuable property in the show pen.

By no stretch of the imagination can the Runt be styled a handsome or attractive Pigeon as a show bird, neither is it elegant or graceful when on the wing. Runts have the quality of tameness, however, and will walk and strut about their home like unto the ordinary fowl. During the breeding season Runts must be liberally supplied with shell grit, so that they may be able to shell their eggs well, as owing to their enormous size they are apt to smash their eggs; and for this reason they must also be given an abundance of material with which to line their nests. Apart from show purposes, and taking it as a 


\section{Pigeons and All About Them.}

utility bird, the Runt cannot be beaten, and anyone fond of Pigeon-pie might make Runts pay by breeding only for the table.

\section{THE POUTER}

This Pigeon has been held in high esteem by fanciers in all ages as one of the leading or classic varieties, and by reason of its grace and gentleness has been given the style and title-the Queen of Pigcons. I am not going back to delve from the chronicles of antiquity the details of its origin; in this practical age such is not needed. At one time London was a big centre of Pouter breeding, but for some years now Scotland has taken the lead, although, strange to say, I,ondon and the home coun ties are very strong in Pigmy Pouters. Pouters, although large birds, do well in confined or limited accommodation, provided they are kept scrupulously clean.

Pouters are very tame and tractable, and take most readily to the training and petting which is needed to bring ont the points of style and carriage, which play so great a part in the judges' decisions. The first step in training a Pouter is to tame it, get it accustomed to being in a pen, and, if possible, in a place where it can often be seen and talked to. Many fancicrs take their Pouters into the house so that they may become used to people moving about near them. When the birds are penned they must be talked to, stroked with the judging-stick, have the fingers snapped at them, and "crooved and cooed" to. These things will all excite the birds and make them strut and stalk about their cages in a dainty yet dignified style, the while blowing out their crops in the approved manner.

Some birds respond most readily, and these make the best birds for exhibition. A merry bird pleases a jucige, a sulky one annoys him, and it is waste of time and moncy to exhibit birds which are inclined to sulk, no matter how good they may be structurally. 
When the birds are placed in the pens they should be treated to a few dainties such as canary seed and hemp seed, each time their owner enters the loft or pen room. This will go a long way to overcome any shyness or sulkiness which any of them may possess. Patience and perseverance bring their own reward so far as the training of Pouters is concerned, but it must ever be remembered that it is useless to show untrained Pouters.

The outstanding features of a Pouter are size and shape. Its body must be long and slender, and narrow in the waist. Its size is more apparent than teal; that is to say, it is not really so big as it looks. Its spread of tail and blowing of crop make it appear big. Fineness of body and fincness of limb lieing great essentials, the bird cannot be big.

The crop or globe of the Pouter is its chief characteristic, the one point that distinguishes it from all other Pigeons. This must, when inflated, be large, full, and round, well balanced on either side of the neck; a crop that is not well balanced is not symmetrical, and fails in its chief point. When at rest it must have such power of elasticity to prevent its being pendulous, a "slack crop" being a bad fault.

The legs should be long, about seven or eight inches in length, set well back in the body, with a slight inwarcl slope to the hock, the shank being straight. They must be close together, so close that when vicwed from the side they appear to touch. The feet must be well formed and well spread, so as to support the body well when the bird is showing. The feet should turn outward. Thus, unlike other Pigcons, a Ponter is not "Pigeon-toed." This allows for the display of the foot feather. The limbs must be closely feathered right down to the toes.

Length of body and length of feather are features of importance. From the tip of its beak to the end of its tail, a high-class Pouter should meastre about 20 inches. Wuch of this length is in the tail. The neck shonld be long, as upon the length of the neck depends in great measure the crop development. The shoulders should be small and 


\section{Pigeons and Ali, About Them.}

well clipped into the sides of the body; the flights must be long and wide in web, extending almost to the end of the tail, and carried just above it. The tail is long and fine, and carried in a continuous line from the body, and must not be allowed to drag, but be carried just off the floor. That Prince of Pigeon Fanciers, the late "Bobbie" Fultan, used to say, "A Pouter should not sweep the floor."

Skull properties are of littie account in a Pouter. The head and beak are dove-shaped, the wattle small and neat. The beak colour varies according to the colours. In Blacks and Blues it should be black, in Reds and Yellows of a horny flesh tint, and in Whites a light flesh tint.

The eye of the Pouter is small, and carries little cere. In colour it is dark or 'bull' in Whites, and yellow or orange in the other colours.

Carriage is a great feature in the Pouter, and when in full show a bird should be almost perpendicular from the eye to the feet. A good bird is most active in carriage, and thus is scarcely two seconds in the same position. No pen can describe the ever-changing attitudes of a free playing Pouter. Action covers much, and it must be seen to be understood.

The standard colours of the Ponter are Blues, Blacks, Reds, Fellows, and Whites, whilst such as Mealies, Cheruters, and Strawberries are considered off-colours. Although one speaks of Ponters as though they were whole-coloured birds, ther are not, as the under part of the body, sides, legs, back, and primary flights are all white. In addition to this, the crescent marking extends from just below the cyes right across the crop, and is, as its name denotes, a half-moon white marking. Then there is the shoulder marking, commonly called the rose, which should be a mottling of the shoulders by about a dozen white feathers, and, to be perfect, he almost in the shape of a rose.

Blues are the most poptlan and most largely bred. Blacks are very handsome, but the colours which appeal most to the enmest brectur are Reds and Yel- 


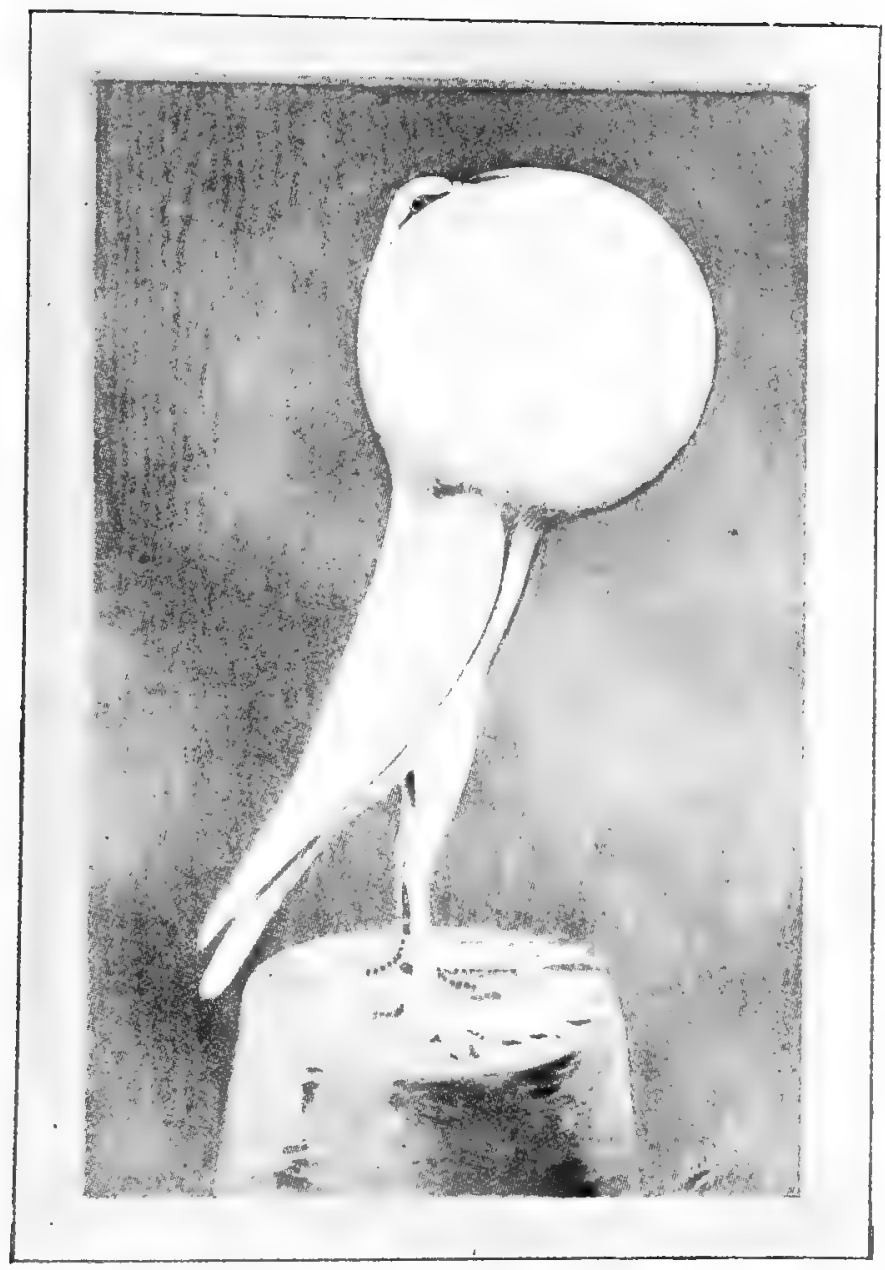

\section{White Pigmy Pouter Hen, "Lady Bayardo,"}

Winner in 1907 of lst Tiverpool and 1st Folkestone; in 1908 of 1st and ('up tor second best Tigeon in show. Leatherlead; and in 1909 of 1st and Challenge Cup for best Pigeon in show,

Leatherhead, and 1st and White Challenge Cup, Club Show, Cambridge.

Bred and Exhibited by Captain St. John Hornby. 

lows, which in Pouters, as in many other breeds, seem all too difficult for the average fancier to breed up to the standard. The chief failing in Red and Yellow Pouters is deficiency in tail colouring.

\section{P'IGMY POUTERS.}

The Pigmy Pouter is one of the breeds which has made extensive headway during the twenticth century, not only in merit, but also in the numbers of its adherents. It is, in all things except size, the exact counterpart of the Pouter; there is, however, this difference, that whereas Pouters, if they possess slimness and no coarseness, cannot be too big. on the other hand the Pigmy, whilst possessing the characteristics of the Pouter, cannot be too small. Today we have quite a number of Pigmies which are, indeed, veritable miniature Pouters, and their number is increasing. In shape, style and limb the Pigmies have much improved of late, and they are still improving.

The colours are blues, silvers, blacks, reds, yellows, whites, chequers and duns, and judging by the numbers shown their popularity is in the order in which I have given them.

\section{THE NORWICH CROPPER.}

This is a very old variety which, in these latter days, has come into favour again. In the days that are gone they are supposed to have played a big part in the making of the English Pouter. I remember, many years ago, before I had much to do with the Pigeon Fancy, how I used in my visits to Norwich to see huge flocks of Croppers about the stable-yards and farm-yards, in and near the city. In those days they were kept for their flying properties; and very attractive indeed are the aerial performances of a flock of Croppers. To-day the Norwich Cropper is a highly esteemed member of the show family, and is to be found scattered throughout the country.

There is a striking resemblance betwcen the Pouter and the Notwich Cropper, and yet at the same time great differences. In the Pouter, length of limb is the great featurc. Not so in the Cropper. The 
legs of the Cropper should be shorter and straighter than those of the Pouter. A Cropper must not have the appearance of being on stilts. Its crop is rather more globular than that of the Pouter, especially on the under portion, coming sharper into the body than does the crop of the Pouter, due, no doubt, in great measure, to the fact that the Cropper is straighter in body than the Pouter.

The colours are Blacks, Blues, Reds, Yellows, Silvers, Duns, Mealies, and Strawberries, with chequers from the Blacks, Duns, Reds and Silvers.

During the show season Pouters, Pigmies, and Croppers are usually kept in pens, and not given their liberty:

\section{FOREIGN CROPPERS.}

On the Continent there are a number of Pouters or Croppers such as the French Pouter, the Austrian Brunner, the Saxon Cropper, the Pomeranian Cropper, the Dutch Cropper, and the Holle Cropper, but of these the only one that may be said to be known and kept in this country is the Holle Cropper, described by Mr. J. C. Lyell as the Dutch Balloon Cropper, or "Die Hollandische Ballonkropftaube," and from the description given of it in "Fancy Pigeons," I should say that Mr. Lyell not being personally acquainted with the breed copied the same from some German work on Pigeons.

The Holle Cropper is a small, round bodied Pigcon, similar in shape to the Fantail, except in its caudal appendage, has a certain amount of the tremulous action of the Fantail, its head is thrown back in the same manner, and rests lightly in the middle of its crop. It has short flights and tail, short legs, and walks in the same graceful yet jaunty manner as the Fantail. Its chest is round and fu1l, and the crop instead of protruding from the front of the bird as in all other Croppers, is held upright above the shoulders. The crop is in keeping with the size of the bird, and is round in shape. It is a grave fault for a bird to be over-cropped, even as it is for it to be under-cropped. Symmetry and proportion are the great essentials. In Holland it is 


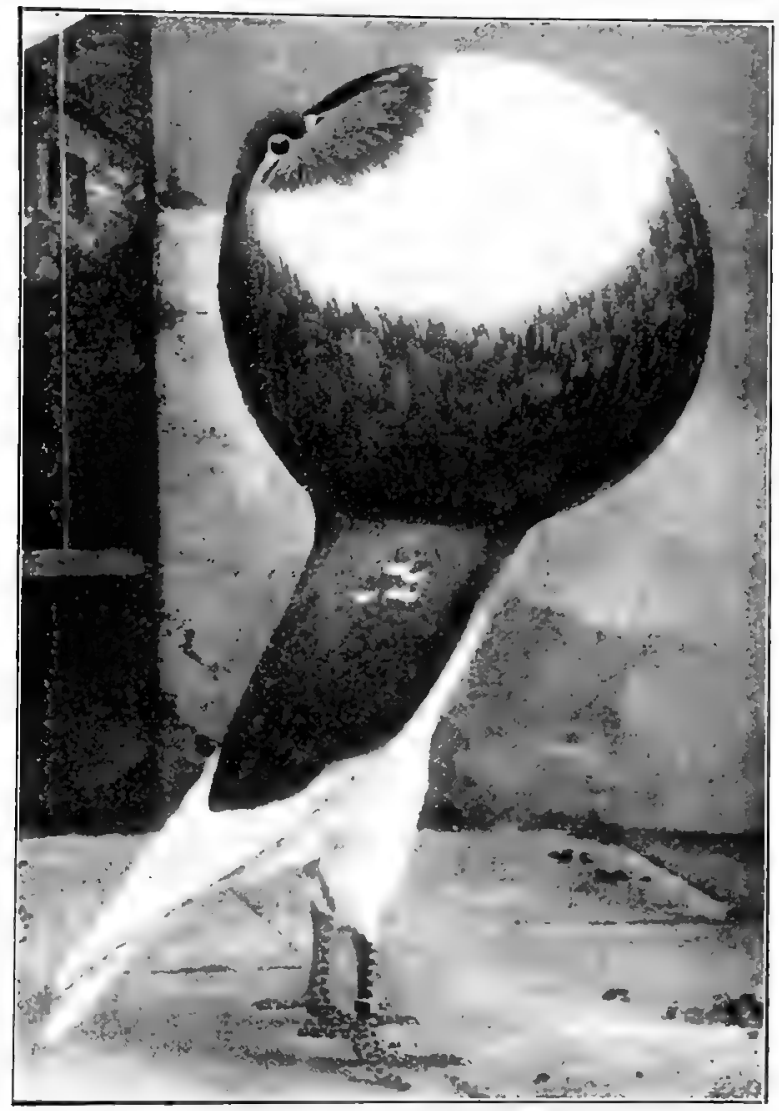

[From a Painting by Wippell.

\section{Red Norwich Cropper Hen.}

Tinner of:-1915, End Dairy (heaten hy a cock). 1st Club Show, 1st and spl Glasgow: 1916, 1st and spl Manchester, 1st and spl Norwich: 1st and spl Cluh Show: 191\%. 1st and spl Club Show, 1st and spl Norwich.

Bred and Exhibited by Dr. Wm. Royden, of Fleggburgh. 

quite the most popular of all Pigeons, having a very strong and active specialist club to look after its interests, and which club holds its annual show at The Hague. At this show classes are provided for whites, blues, blacks, reds, vellows, grizzles, mottles, blue, black, red, and yellow pieds, and the same colours with white flights. Some ycars since the Holle Cropper Club, at its annual meeting bestowed upon myself a unique distinction by electing me its "Meniber of Honour," as a mark of its esteem, and in recognition of my labours and writings on behalf of the columbarian family. This makes me the first nember of the club, takitig precedence even of the president, thus the honour is, indeed, a great one.

\section{THE SHORT-FACED TUMBLER,}

Amongst the Tumbler family are to be found possibly the oldest of our Fancy Pigcons-the Shortfaced. At one time it was the Pigeon above all others known to the Fancy, special societies with regular meeting-nights beino devoted to its culture, especially in London. That it is essentially a bird adapted for large towns is not to be denied, because it does not require a great amount of room. As to the varieties, these are Almonds, Agates, Kites, Mottles, Selfs, Baldheads, and Beards, and by general consent the Almond is voted the king of the family. The Mottles are, perhaps, the most valued, but they are in so fiew hands, and are so seldom seen in anything approaching perfection that the palm must be given to the Almond.

Before proceeding to describe the colours of the varions Tumblers, I will deal with their structural properties. There is not much doubt that the reason why Short-faced Tumblers fell from the high esteem in which they were held was because of certain revelations some years ago as to the means adopterd by fanciers to produce the peculiar shape of skull. The effect of those disclostres has passed away, and now the Short-faced Tumbler is becoming more popular again. 
The beak of all Short-faced Tumblers should be short, fine, and straight, like unto the beak of a Goldfinch, hence the term, "Goldfinch beak." The wattle should be very small, fine, and neat.

The skull, more generally known as "the knob," is a great feature! It is amongst all breeds of Pigeons most distinct in character. In no Pigeon of any kind have we anything approaching the Short-faced Tumbler in its shape of skt1ll, or "knob." The frontal should be full and projecting, rising abruptly from the beak, and being nicely rounded off at the top, the crown being large and circular. The width and height must be in due proportion, and whilst a lofty skull is of great value, that value is heavily discounted should there not be proportionate width. The frontal should be so prominent as to bear the appearance of overhanging the beak. The cheeks should be full and rounded, the feathers betwoen the eye and the under mandible bulging out towards the eye.

The eye in all colours should be white, pure milk-white, and surrounded by a very fine cere, although this being a minor point many otherwise grand birds fail therein.

In body the Short-faced Tumbler should be small. The neck should be thin and well arched, showing off the peculiar skull properties, and also adding to the beanty of carriage. The chest should be short, very full, wide and projecting. The back and keel short. The fiights should be carried below the tail, in the manner known as "drooping."

Carriage and shape have much to do with each other, as unless the body is correctly formed the carriage cannot be what is required. Thus the shortness and compactness of body have much to do with graceful, alert carriage, which is so great a feature of the Short-faced Tumbler. The legs and thighs should be short, the feet small, vet very muscular and springy, enabling the bird when in full show to gain a very dainty pose by standing tip-toe. The flights and tail, although short, are rather long in proportion to the length of the body, and are not very compactly cartied. 


\section{THE COLOURS.}

Alaonds. - Ithy so called has becn the subject of contention time after time, but the generally accepted idea is zilat it is so called from its ground colour, and which, after all, seems the most natural.

Common sense says the Almond is so-called because its ground colour should resemble the colour of the outer shell of the almond nut. This colour should be rich and clear, as it is the distinctive property dividing the Almond from other colours. This colour begins to deepen and spread from an early age. Few birds are broken in colour until the first moult has been through, but some even in their nest body feathers are ticked and spotted with black. After the first moult these marks continue to increase and grow larger. After the third, or second adult moult, the bird is generally at its best, so far as "spangling" or brokenness of colour is concerned. The tail and flights of a matured specimen should be of three distinct colours, black, yellow, and white, the marking being clear and distinct, and not showing any tendency to intermingle. I may say the Almond hens are never so sharp or clear in spangling as the cocks.

Motthes. - These, as I have said, are seldom seen, but they are indced most beautiful, and highly valued when they approach anywhere near the standard. One advantage the Mattles have over the Almonds is that their beauty is more lasting. The glory of the Almond is of a fleeting character, and no sooner attains its summit than it begins to change and go back, the bird getting too dark. Not so the Mottle; its beauty lasts until death. The deep, tich ground colout of a good black Mottle, relieved with evenly formed rose markings on shoulders, and a good clear $V$ on the back, is of the most fascinating and enchanting character.

AGATES. - These are generally Reds and Yellows, heavily splashed with white. They are inter-bred with the Almonds, and are chiefly remarkable for the fact that they excel the more highly valued Almond 
in "knob." Splashes are Agates with black splashes about them, generally in the flights and tail.

SELFS.-These, as their names denote, are whole, or self-coloured birds.

KiTEs.-Are really Blacks, with a bronzy or reddish tint running through the feather; the black - should be a rich, deep black, not a dull, slaty colour.

\section{THE BREEDING OF ALMONDS.}

How the Almond originated is somewhat of a mystery, even as its breeding is a matter of great intricacy. I have not the space to enter into the matter, and can only direct the young aspirant into roads which will give scope for his own ingenuity and ferility of resource. A show Almond, that is a bird approaching perfection, should be mated to an Agate which is whole-feathered, that is one in which the white marking is only to be found in the flights and tail. Almond cocks that fail in ground colour, but are wall spangled, should be mated to a good, bright coloured red hetn, or a rich lustrous Kite. Kite and Agate cocks should have Almond hens as mates. Agates and Kites when paired will also produce Almonds. Splashes when paired to whole or selfcoloured reds and yellows will nearly always show a good proportion of Almond progeny. The matings depend to a very great extent upon the family history of each Pigcon, and it is most essential to success in Short-faced breeding that the fanciet keep a most careful record of his matings and their produce.

BALDHEADS AND BEARDS.-These have ail the charactoristics of the family, with the markmgs which give them their distinctive names. Although not so numerous as they used to be, there is still a goodly number of Baldheads and Bcards bred, and an effort is being made by a few enthusiasts to raise them to their former high estate. The colours are black, blue, red, yellow, and silver, the two former predominating. 


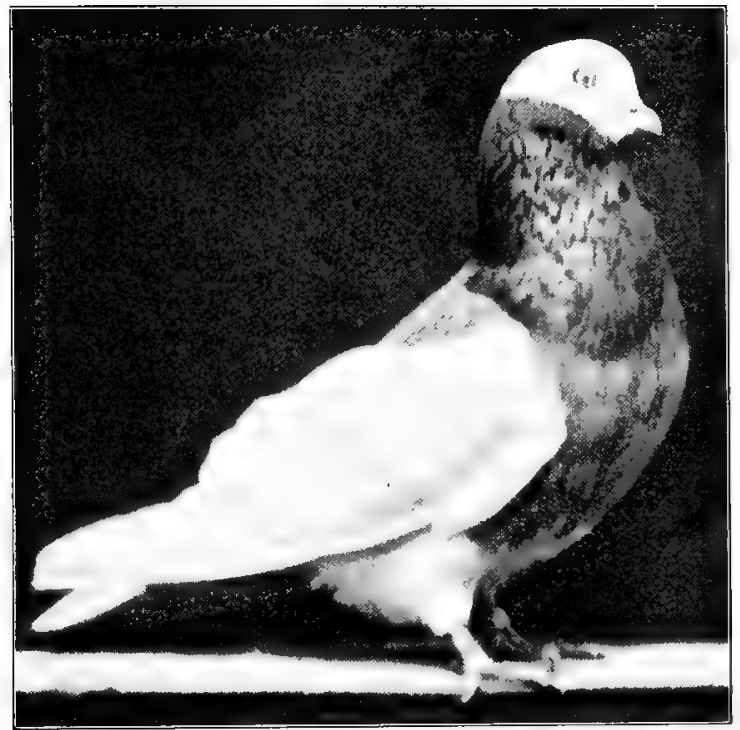

"Pigeons" Photo.]

\section{Blue L.F. Saddle Bald Tumbler, "Billy."}

Winner of 1 st and A.O.V. Ch. Cup, gold centre medal, "Tom MaGregor" sp, and reserve for medal hest Tumbler Bath L.F. Tumbler Club Show; 1st Midsomer Norton, 3rd lidinbulgh, 3 rd Oakham, reserve Bristol, only times shown.

Bred and exhibited by Mr. W. L. Langley, the originator of the Variety. 



\section{THE LONG-FACED TUMBLER.}

The Long-faced Tumbler, in one or other of its many sub-varieties, is generally recommended to the novice when he asks what variety is easy to breed. This is somewhat resented by enthusiastic followers of the Long-faced, who say, "Let those who think Long-faces easy to breed have a go at them." Whilst not wishing to unduly ruffle the plumes of Longfaced breeders, I must say the advice so given is sound, because Long-faced Tumblers are fairly reas'nable in price, they do not require extensive acc mmodation, and being most excellent parents they rear their young without much assistance from their owner. Further, they are hardy and prolific, and so far as the Selfs are concerned fairly easy to exhibit, little being required in the way of preparation Therefore, what breed could be better adapted to tice needs of a novice? Tumblers are charming littla birds, and they will keep his affections until he has learnt something of the art of keeping and breeding Pigeons, and then, if so inclined, he may try his luck with some of the brecds which are not so cheap, not so hardy, not so prolific, and not such good parents.

In the same manner as I dealt with the general characteristics of the Short-faces, so will I deal with the Long-faces, and then proceed to speak of the distinguishing features of the different sub-varieties.

Beak.-Close fitting, straight set, and fairly stout; a fine spindley beak is a great fault.

Wattle-Very neat, evenly placed, and fine in texture.

Skull.- Rather more oval than round, with plenty of width in front, and without flatness of crown, or angularities of any kind.

Eye.-In colout the eye should be pearl or white, a milk-white being the acme of perfections. The eye should be centrally placed so as to preserve the balance of face and back skull, and also top. fitting.

Ceres.-Very fine in texture, small and close 
Neck.-Medium length, slightly arched, and widening gradually from the head to the shoulders.

Body.-Short and compact, wedge-shaped, chest very full and prominent, with plenty of width. Narrowness is a great fault.

Flights and Tail.-The flights should be short, closely set, possess nice strength of feather, and be carried over the tail. The tail should be fine, neat, and closely folded. Slovenly carriage of flights and spreading of tail are faults of some magnitude.

Legs.-These should be stout and well set, and of medium length, the feet being clean and neat.

Plumage.-The feathering throughout should be clean, short, and tight fitting, except, of course, in muffed varieties, where greater length of feather is found.

MOTTLES AND ROSEWINGS.--In dealing with the sub-varieties, I take the Mottles and Rosewings first, because to me they are the highest form in which the Long-faced Tumbler is bred. There is no Pigeon on the bench more beautiful than a highly finished, rich coloured, stylish, well marked Black Mottle Long-faced Tumbler.

The difficulties to be met with in breeding Mottles and Rosewings are many and great, and they cannot be surmounted nuless the breeder has the most intimate knowledge of the stud of birds with which he is operating, and that knowledge can only be acquired and kept by a careful and systematic use of a stud register. The great failing which Mottle breeders have to fight against is the tendency which birds have to come too gay or light in marking.

To go thoroughly into the mysteries of Mottle and Rosewing breeding would requite a special treatise. I can do no more than direct the breeder's attention to the fact that two gaily marked birds nunst not on any account be paired together; under marked birds mist be bred to those that are well marked, and gay ones to Mottle-bred Selfs, and so on. These are only general tules. Each individual stud possesses characteristics of its omn, and these must be mastered ere success can be achieved. 


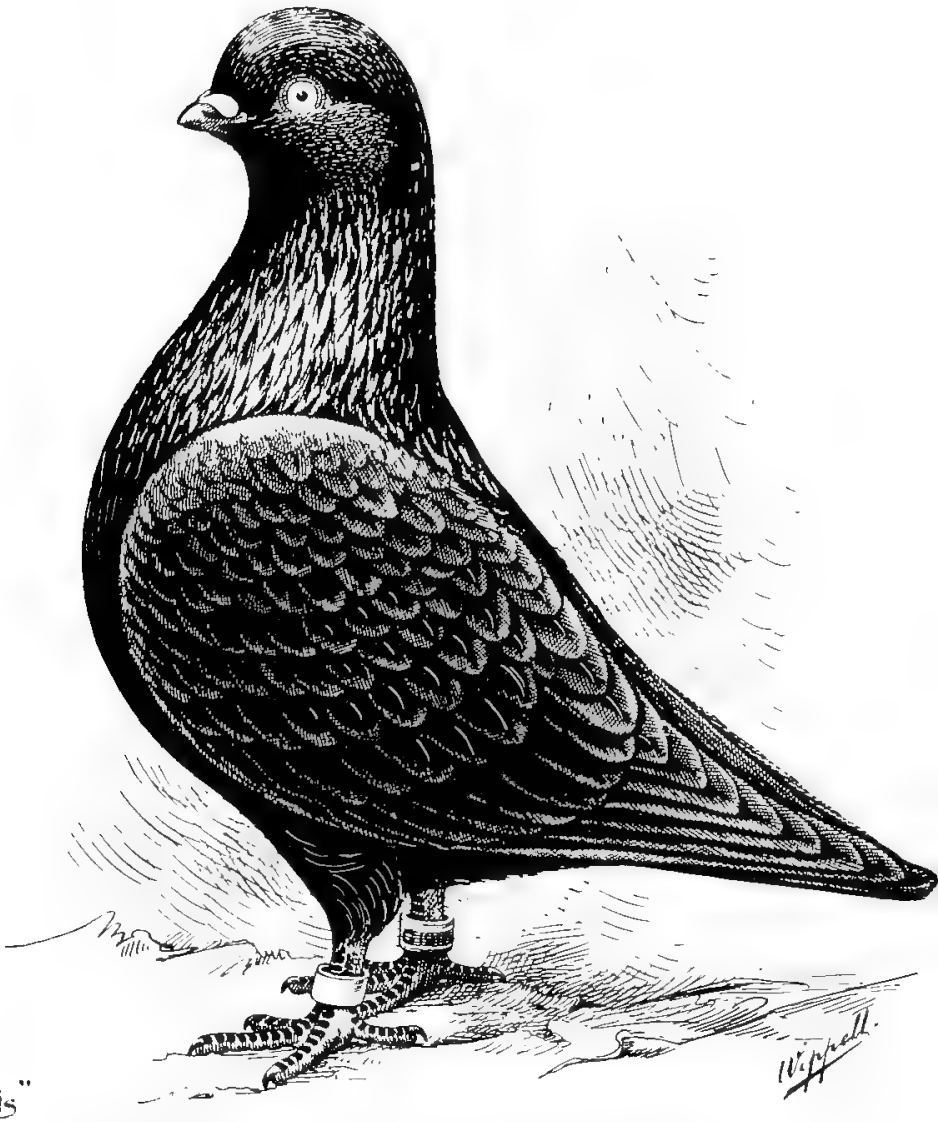

Long-faced Black Self Tumbler Hen, "Carrol Gem."

A well-known winner, and described by her owner as the best he ever bied.

Bred and Exhibited by Mr. C. P, Hammond. 

For the benefit of the new hand, I may say that the best red and yellow Mottles are, generally speaking, Selfs, or almost Selfs, in their first feather, whilst on the other hand, the Blacks carry more white than they do after the first moult.

Reds, Yellows, Blacks, and Whites are the colours in Mottles and Rosewings, the Whites being very few and uncommon. In the three former the marking on the shoulders should occupy a space about the size of a five-shilling piece, and be composed of white feathers, so arranged as to form a nice rose marking. The back marking should take the form of a $V$, extending from the nape of the neck to half way down the back. This marking is sometimes spoken of as the $\mathrm{V}$, at others as the "handkerchief." The Mottle and the Rosewing differ only in that the last-named has no back marking. In Blacks, Reds, and Yellows the marking is white upon the dark, or ground colour, and in the Whites the marking is black.

BALDHEADS AND BFARDS.-These are found in the following colours: Black, Blue, Silver, Red, Yellow, and Blue Chequer. In head properties the Balds are generally better than the Beards, the latter not showing such width of skull, or so much fullness of frontal, as the Balds, Blacks, Blues, and Balds. Each should have sharp, clearly defined black wing bars. The Reds and Yellows must be as sound and even as possible in their ground colour. The flight or wing marking in each is the same, the standard perfection of value being rox ro. That is, the ten outer flights on each wing are white, the remainder being of the body colour of the bird.

The Baldhead's distinguishing marking is, of course, the head, which should be white, cut away from the body by a sharp line very slightly below the eye. If the line goes below this the bird is termed "low cut," as opposed to "high cut." A high cut bird is the most valuable owing to the difficulty in keeping dark feathers off the skull in high cut birds. The back, rump, tail, and underpatt of the body are 


\section{Pigeons and Ali About Them.}

white. The beak is white or flesh-coloured. The cere in the reds and yellows is light, but in the other colours should be clark.

Since the second edition of "Pigeons and All About 'Them" was published, that good fancier, Mr. IT. L. Langley, of Bath, has introduced and perfected a very handsome Baldhead Tumbler with Saddle markings. This is known as the Saddlemarked Baldhead, and is a very pleasing addition to our varieties of Pigeons. The variety is not yet admitted to the standard of the Bald and Beard Club, but that is only a question of time.

The Beard receives its name from its white marking immediately below the under mandible. This beard, or "chuck," as it is more commonly called, should be smail, not extending beyond the centre of the eye on either side, and of a semi-circular shape, and going from half an inch to two-thirds down the throat. The thighs are often white and are so passed, but if the colouring can be carricd down to the vent the bird is improved, and this colouring the standard asks for, but mally otherwise good birds fail in this property. The tail and stockings (that is the leg feathering) should be white. In Blacks, Blues, and Chequers the upper mandible should be dark or black, and the under one white or flesh colour; in the other colours both mandibles should be light. The eyce cere in all colours should be as dark as possible.

IVHITESIDES. - The name indicates what these birds should be. Reds, Yelloms, and Blacks are the colours, the two former being the most common; in fact, very few of the latter have been seen in the show pen. Whitcsicles should have the whole of the body and the ten outer flights of each wing solid in colour, the rest being white. The IThitesides have been bred down from light or gay colouted Mottles, and have had their markings fixed by careful selection. In their nestling feathers Whitesides are almost if not quite Selfs, therefore anyone taking them up must not expect to see the beauty of their marking until after the moult. The beak in Reds and Yellows should be flesh-colonred, and in Blacks follow the 
body colour. The cere in all is flesh-coloured, but black or dark ceres would greatly improve the appearance of the Blacks.

SELFS.-These are the popular and most extensively brecl of any of the Tumbler family, and this is no doubt duc to the fact that the brceder is not troubled or worried with markings. He has only to get his colour and structure right. It 11nust, however, be remembered that if Selfs are easier to breed than the marked varieties, that they have to be bred to a higher standard of excellence owing to the keenness of the competition, and that it is almost as difficult, if not more so, to become a leadling light in the ranks of Self breeders as it is amongst breeders of Mottles or Balds and Beards.

After the structural properties colour is the Alpha and Omega of the Self Tumbler; and if one would excel in selfs it is above all thipgs necessary that great attention be paid to the breeding of birds with rich, sound, even colour. Blacks, Reds, Yellows, and Whites are the prevailing colours, the Blacks being the most numerous and the Whites the least. Blues and Silvers are also bred, but as they are barred it is a moot point if they can be admitted as Selfs. Some contend that they are, others say no.

Blacks should be a rich, deep, solid glossy black, covered with a bright beetle-green sheen. should be dark, also the beak.

REDS should be a bright, deep chestnut red throughout, showing no pluminess, sootiness, or mealiness of colour.

YelLOW, like Reds, must be of one even shade of colour throughout, not a cold, hard looking colour, but a warm, rich shade. Common faults are mealiness of body colour, and greyness or ashiness of flights and tail.

Yellows and Reds are greatly affected by the sun, and provision must be made for shielding them from its direct rays. If the sun and rain are allowed to reach them it is impossible to maintain the beauty and colour of their plumage. 
WHiTes must be a pure dead white, and not show traces of greyness or splashes in plumage. Reds, Ycllows, and Whites should have light beaks and ceres. Stained beaks are a common failing.

TIME BARRED VARIETIES.-Few of the cleanlegged Tumblers are barred, yct there are a few Blues, Silvers, Mealies, and Clicquers to be found amongst thenl. In the inuffed-legged varieties they are fairly colmmon.

BLuEs should be a nice even medium shade of blue, not so soft and larender-like as the blue of the Ow1, and not so dark and hard as the Dragoon colour, but nearer to the latter than the former. General failings are a tendency to lightness on rump, vent, and thighs.

SILvers should be a soft, silvery colour, not creamy, but approaching the hue of a newly-minted shilling. They generally fail in purity of colour, some being of a creamy tint, others showing a washiness or lightness of vent, rump, and thighs.

Chequers should have the ground colour of whaterer hue they may be clear and sound, and be closely and evenly chequered all over excepting the neck. Blues and Chequers should have dark beaks and ceres. The Silvers are generally lighter in cere and beak, but the fancicr who can establish a strain with dark ceres and beaks will make for himself a great name.

The bars in all colours should be a dense bright hlack, and sharply and distinctly defined.

Almonds are only few in number and fewer still ruach a high standard of merit. The colouring is the same as in the S.F. Almonds.

Those who wish to know more about the Longfaced Tumblers should consult my book, "Longfaced Tumblers, and All About Them," which is also published by "Pigeons."

\section{THE MIUFFS.}

The MIuff-legged varieties, which are to be found in all colours, should have a profusion of feathers from the hocks downward, the longer the better, and it should extend to the toes. 
These are great favourites in and around Birmingham: in fact, in the great Miclland city there are more breeders of these handsome birds than in all the rest of the kingdom besides, and they yearly make a good display at the Bingley Hall Show in their own city, but beyond that very few are seen.

SADDLES are marked on the borly in a manner similar to Magries, with the addition of the heard and whiskers. The beard is a white marking which should extend from the cyce to the beak on each side, and a short way down the throat. A string of white also runs from the throat marking, commencing at the back of the eye and rumning up the neck to the back of the head. There is also a white spot just above each eye, and a blaze mark on the forchead. The whiskers are a patch of colour on each side of the mouth, between the forehead spot and the throat or beard marking. such marking, I need hardly say, is seldom scen approaching perfection.

BADGES are practically whole-coloured hirds, except that they have white outer flights, and face markings similar to the Saddles.

Saddles and Badges are found in great varicty of colouring, blues being the most common, follorred by blacks, reds, ycllows, silvers, and chequers. They are, of course, heavily muffed.

\section{THE TIPPLER.}

The Tipller belongs to the Tumbler family, and has of recent years been brought to a high state of perfection as a show bird. Show specimens being far removed in shape, colour, and marking from the oldfashioned flying or Macclesfield Tippler, from which it slirung. Ther are clivided into Dark Mottles, Light Mottles, Chucks, Browns, and Bronzes. The two latter are self-coloured birds, as their names denote. The Chuck has a coloured chuck, and the primary flights are also coloured. Dark Mottles should be of a rich bronze ground colour throughout, with markings on the back and shoulders. The Light Mottles have a light ground colour, and should be evenly marked or mottled all over with rich brown marking 
or mottling. In both Dark and Light Mottles the flights and tail must be sound in colour.

Shape and carriage should be similar to that of the Clean-legged Long-faced Tumblers.

\section{THE CUMULE'T.}

Of ancient lineage and great popularity the Cumulet was introduced into England from Belgium where it had long been known as one. of the high-flying breeds, and much used by Belgian fanciers in the evolution of "the Pigeon Voyageur" or Racing Homer, its great value in this direction being its high flying propensity. English Cumulets are white, or white with slight red marking about the throat, known as the "chuck," but on the continent coloured firds are also known, such as blacks and reds, with white flights and tails. When first introduceil to English fanciers it was as a flying bird, but it was not long after its advent nnto this country that it was introduced to the show pen. As an English show Pigeon it has increased in size and in style, but at the expense of its flying properties. To remedy this the Cumulet Club some time since organised a flying section with conpetitions for tle longest flying. Cumulets when on the wing reach such heights that it is impossible for the ere of their owner to follow them, and they will sometimes remain out of sight for eight or nine hours, when "the kit" will suddenly drop and enter the loft as lively and as merry as though it had only been on the wing for minutes instead of hours. When liberated from the loft "the kit" flies round and round in circles, gradually monnting higher and higher, and in dropping to the loft at the end of the flight the birds approach their loft in the same manner.

As a fancy or exhibition Pigeon, the Cumulet is most attractive and quite unlike any other bird known to English fanciers. Its clear white ere, and white cere, combined with its snowy plumage marking it out for a distinctiveness entirely its own. It is a bold active looking bird, very smart and compact in plumage, and attracts attention by its alert and fearless 


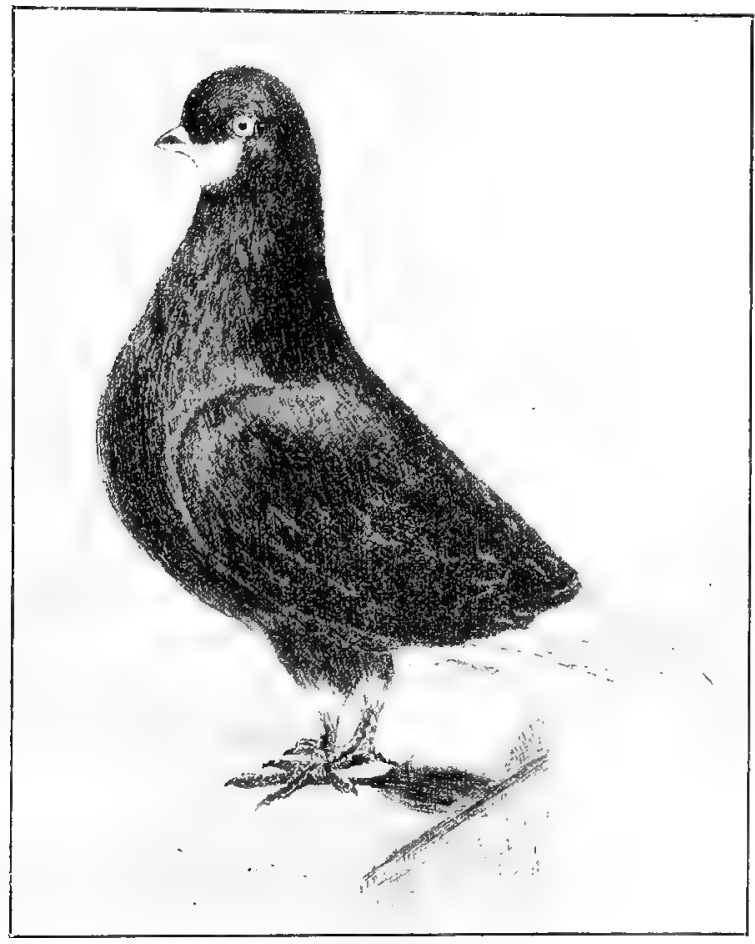

[Sketched from life by Miss Fouler.

A Famous Long-faced Black Beard Tumbler.

Bred and Exhibited by Mr. W. H, Fowler. 

carriage. Its beak which is flesh-coloured should be straightly set on and of medium substance. The wattles should be small, fine, glovelike in texture, and white in colour. The face should be long, well drawn out, and nicely filled so that it presents a long even sweep, rising graclually from the wattles to the top of the sliull, which should be nicely rounded at the back, falling into the neck without any break or angularity. The eye, the most distinguishing characteristic of the Cumulet should be clear white in the iris which is large in proportion to the size of the eye, the pupil being correspondingly smaller, the cere should be very fine and white in colour. The body is like unto that of the old-fashioned Flying Tumbler in shape, but is larger in size, the keel being of medium depth, with a bold chest, strong powerful looking wing butts, carrying strong broad flights of good length, well above the tail, which should be horizontal and off the ground. The legs should be clean, free of feathers below the hock, and of a length proportionate with the body so as to give the bold alcrt carriage which is so strong a feature of the breed. Condition is an important factor in the show pen, and thus, unless a Cumulet is " in the pink" it possesses little chance of success. Lancashire and Cheshire are the strongholds of the Cumulet Fancy, the breed having few followers outside these counties. Why it is difficult to say.

\section{THE ENGI_ISH OWL.}

The Finglish Owl is a very widely bred and highly polular member of the Columbarian family. Further, it is bred and kept by fanciers of high position in the Fancy, it being one of the most valuable of our Fancy Pigeons. In fact, to the Owl belongs the credit of having fetched the highest price in the records of the Fancy. An English Owl, which was brecl by that most estimable fancier, Mr. Stephen Salter, of Ryde, having been sold for 200 .

The English Owl of the present time is a vastly different Pigeon to its ancestor of thirty or forty years ago. In those days it was smaller in both head and 
body, the increased size and substance having been obtained by the introduction of the Barb and Shortfaced Antwerp.

Some say it is not so, others of the progressive fanily say they have done it. One thing is certain, and that is that in the Antwerl breeding district of Torkshire many frill-less Orls hare been produced. As a policeman would say if it is not proven, there is ground for great suspicion.

As it is now bred, the English Owl is a bird of noble and commanding presence, and gives one the irlea of strength without clumsiness. It is a hardy hird, and it is not at all unusual for a good show speciment to stand the wear and tear of exhibition life for seven or eight years, and some have stood it even for ten or eleven years. The English Owl should be a fairly large bird, ret not an awkward one. It should have a stout, plump, ret fairly short body, with great widtl and fulness of chest; the wings should be strong and muscular, and carried above the tail; the carriage hold, actire, and jaunty, the hearl heing held well up in a smart, alert manner.

In the head of the Owl lies almost three-fourths of its properties. Let standards say what they will, head and head alone dominates the Owl. Included in head is the beak; this latter property should be stout and short, and of prarrot-like sha1e, not too pronounced in its hook, but if it errs at all it should be in this direction rather than in the opposite of straightness. A straight beaked $\mathrm{Ow}$ is an abomination. The curve in the heak should be just sufficient to keep the outline of rotundlity from tip of the bali over the skull; with a straight beak the heautiful and much-desired roundness of vrofile is broken. The beak wattle should be small, nieat, and of fine texture. In Blues, Powdered Blues, Blue-chequers, and Blacks, the beak chould he dark in Silvers, Silver-chequers, Powdered Silvers, Duns, Reds, and Yellows, it should be of a light horn or flesh colour.

The head should te very round, full, and massive. Vieverl from the front, back, or in profile, the iclea conveyed to the observer should be of roundness in 
front, roundness bchind, and roundness everywhere. This rotundity of sku1l is the greatest and first property in the Owl.

The eye should be large, bold, and prominent, and centrally placed. This latter point is of great importance; the eye cere should be fine and close fitting, and of a flesh colour.

'The gullet should be large and full; in a word, well developed, and run from the beak down to the frill or rosette which adorns the breast. The neck should be short and thick. "Bull-necked " describes it.

\section{THE AFRICAN OWI.}

This charming little bird has many most devoted adherents, and is held in high repute by those who appreciate delicacy and refinement. It should be in all its properties a miniature of the English Ow1. Imported birds are somewhat delicate in constitution, but as we have in the United Kingdom many strains of home-bred birds which have long ago outgrown their original delicacy no one need be deterred from taking up African Owls for fear of sickness and heavy mortality.

The colours most generally seen are Whites and Blacks, and they are the most perfect in points. Other colours are Duns, Reds, Yellows, Blues, Silvers, Lavenders.

\section{THE WHISKERED OWL.}

The Whiskered Owl is rather larger than the African Owl, and yet not so large as the English. In shape and style it resembles these, and its feathering is the same with the exception of the whiskers, which are an extension of the frill running up each side of the face or cheeks.

\section{THE ORIENTAL FRILLS.}

These are a large and extensive family, and are yearly becoming more extensive. They are of all birds known to the Finglish Pigeon Fancy the most varied and delicate in plumage and markings. In a work of the size of this it is impossible to go fully 
into all the points and properties of these exceedingly handsome birds. Therefore, I should content mysclf by giving the iroperties common to all, and give a short description of the most popular and common of the varieties.

In size, shape, and carriage they are similar to the Inglish Turbit. The beak should be short, thick, and slightly curved. The beak wattle rery small and fine in texture. The head round, with an unbroken outline from the beak to the back of the skull. The gullet should be full and long. The frill long and abundant in feather, and opening well out. The peak fine, and carrich well up to a reedle point.

'ГHE SATINETTE.-The blue-laced Satinette was the first of the Orientals to command attention from Finglish fanciers, and is to-day the most largely bred. Its body coloutr should be white, with tri-coloured sloulders, the ground colour of which should be white with clear, sharp lacing of a purplish or reddish brown, but very few are pure in ground colour, the majority show a linky shade. Some birds are chequered at the extremity of each of the shoulder feathers with a triangular mark. This is called arrow-ponted, and such bircls are nore highly estcemed than those that are just plainly laced. Coarse or blotchy lacing is a great fanlt. The tail should be dark in colour, with a clcanly cut white spot on each feather close to the end. A well-marked tail is a great feature of the blue-lacel rariety, but the black-laced and dun-laced have plain tails, except that the shaft of the feathers is clark, and the tail coverts are laced. Satinettes are both plain-headed and peaked.

BRTNETTES, BLTETTES, IND SILERETTES are subvarietics of the Satinette, differing only in colour and marking. The Brunette should have a silver tall, and the ground colour of the shoulders should be of a silvery dun tint. The Bluette should be of an even line colour on the shoulders, with white wing bars. laced with black, and an inner lacing of a darker flesh or rel tint. The tail should be as in the Satinette. The silvetete should be of a silvery ground colour on the showllers, with white wing bars, laced with 
a dark dun, with an inner lacing of buff or yellow. The tail being of the same shade as in the Satinette, or a trifle lighter. Satinettes, Brunettes, Bluettes, and silverettes are inter-bred considerably.

The BlondnetTe.- The Blondinette is marlied and laced in the same manner as the Satinette, but the body colour differs, inasmuch as whcre the Satinette is white the Blondinette is blute. There are blue-laced, sulphur-laced, red-laced, and black-laced, also blue and silver-barred, that is whole-coloured birds with tricoloured wing bars, and spot marked tails. The Blondinettes, like the Satinettes, are grouse-feathered. That is, feathered on the legs.

THE Domno.-This bird is peaked, clean-legged, whole-coloured on the shoulders and tails, and marted on the head like a Nun. Dominoes are scidom seen. The colours are blacks, blues, and silvers.

THE Vhzor.-This breed is said to have been produced by crossing the Domino with the Satinette, and is a bird of great rarity. The head and shoulders are coloured. It is grouse-legged, and may be peaked or plain-headed like the Satinette. The most common colours are blue and silver.

THE TURBITEEN is a very charming cxample of the Oriental family. It is a white-bodied Pigeon with shoulder markings like the English Turbit, with a frontal spot and cheek markings, each clear and distinct, and the cheek markings about half-an-inch in diameter. Most Turbiteens are plain-headed, but peaked birds are to be seen. They are grouse-legged. The upper mandible of the beak should be dark, and the lower flight flesh colour or white. Blacks and Blues are the most common colours, followed by Reds, Yellow's, Silvers, and Chequers. In all the colours are generally very bright, rich and clear. They are a quaint and most attractive variety, but unfortunately are in very few hands.

The Oriental Tureit.-This is coloured on the shoulders like the English Turbit, with the addition of a coloured tail, and is plain-headed. It excels in head and beak properties, and has been used by Eng- 


\section{Pigeons and Ali About Them.}

lish Turbit breeders to improve these properties, especially since English T'urbit breeders began to place a high value on frontal or bulge.

\section{THE ENGLISH TURBIT.}

This is one of the smartest and prettiest little birds we have, and it is one which has a large and increasing band of devotees. Turbit breeders are as a whole a most enthusiastic and zealous lot of fanciers, and the manner in which during the past two decades they have improved the breed is deserving of the highest praise. The Turbit, like the Owl, is judged principally and primarily for its head properties, the body being little thought of. Some may say this is rank heresy. Let them think so. I know it for the truth. The Turbit certainly has body properties, but who ever hears a company of Turbit men discussing colour, shape, or feather? It is head and beak always, and whilst skull properties dominate it must be so. Yet I would remind my readers that away from the head lie some of the most charming properties of the Turbit.

Running through the points of birds, the beak attracts attention first, because unless it is of the 1)roper "Bullfinch" shape, stout, short, well set, the E cattiful outline of the skull is lost. The beak wattle should be wide and heart-shaped, yet fine in substance, and close fitting.

The head should be large, yet not coarse. Its frontal should be very wide and full, and rise in unbroken line from the beak, with the feathers growing, as it were, out of the wattle. The top of the skull is not round like that of the Ow1, but it somewhat flat after the rise of the frontal is left at the eye. By this I mean the back portion of the skull, and it is this which gives the peculiar bolting appearance to the eyes, the ceres of which should be fine and close fitting. The cheeks should be full and chubby. With fulness of cheeks goes another valuable property, wicth of gape; a flat-cheeked Turbit is usually narrow in gape. 


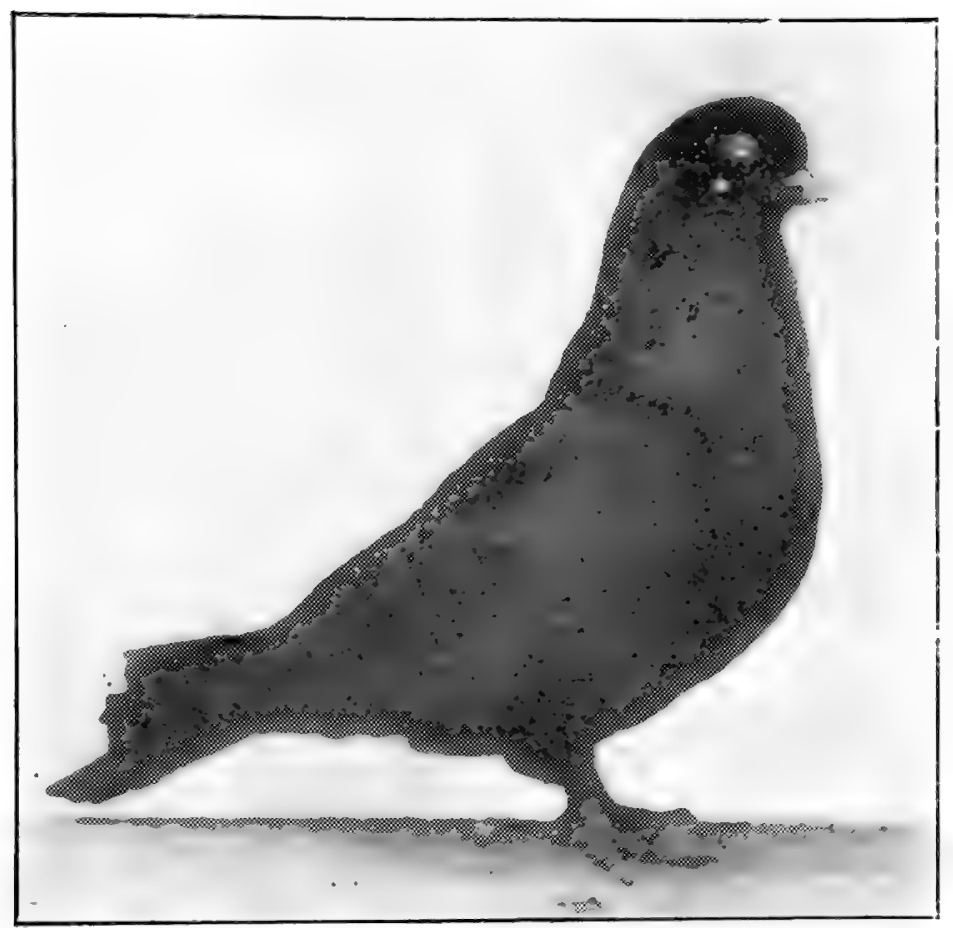

Red Self L.F. Tumbler Hen, "Idle Jean."

Winner of three 1sts and sps at the Long-faced Self Tumbler

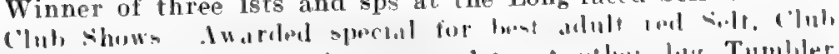

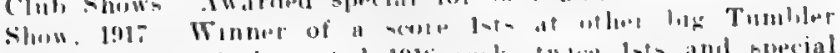

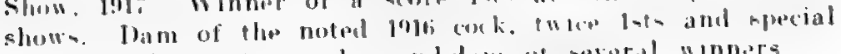
club sluw, etc., and gatudel.um ot serotal winnors

Bred and exhibited by Mr. Geo. Lappin, 59, Albert Avenue, Idle, gradford, Yorks. 

The neck should be short and thick, with the peak rising up clean and compract to a sharp needle point. The gullet should be full and prominent, and extend from the under mandible to the frill, which should be well feathered ancl partake of the formation of a rose.

The body should not be large, yet not so small as to impair the constitution. In shape it should be cobby, round, and plump, the chest broad and full, with close-fitting shoulders, short, well carried flights and short tail. The legs must also be short yet carry the body in a bold, upright jaunty manner, the head being well poised.

The body colour of the Turbit is white, with coloured shoulder markings, and according to the colour of the shoulders clo we get the style or name of the Turbit-Black, Blue, Red, Yellow, Silver, Dun, Strawberry, Mealy, with their corresponding cheruers. Blacks are the most numerous, and, speaking generally, are the best developed in head points, although during the last few years some wonderful skulled Blues have appeared. Reds and Yellows are far behind in skull and beak, which is strange considerng how beautiful they are in other respects.

The faults which Turbit breeders have to contend with most strentiously are thinness and straightness of beak, narrowness and flatness of frontal, shelly peak, lack of gullet and frill, foul thighs, and "bishoped," or undermarked shoulders.

\section{THE MAGPIE.}

This is one of the varieties which, during the twentieth century, has come with a rush. It is a Pigeon of many charms, attracting by its beatutiful marking, its richness of colour, and its graceful shape and carriage. That its beauties are highly appreciated is shown by its wide distribution, the large number of classes given to it, and the splendid arerage of entries which fill them in all parts of the country. Years ago the stronghold of the variety used to be in the West, but of recent years that supremacy has been undermined and captured by the East and North. Still the Trest is not by any means a played out force. 
The beak should be long and fine, of a rich flesh colour, and free from stains or marks; although very few blacks are so found, most of them having a dark mark on the upper mandible. At one time this was considered a great fault, but nowadays it is little thought about owing to the extreme importance attached to head and neck. The beak wattle should be very small, and of fine texture. The eye should be milk or silvery white in colour, very prominent and nervous in expression, and be surrounded by a small, very close-fitting cere, of a beautiful, rich, red coral tint, the deeper and brighter the better.

The head should be very long and fine, straight in lace, rising gradually and imperceptibly from the wattle to the top of the skull without stop or decided curve: the top must not be flat, but show just sufficient imperceptible rise without curve to enable the back skull to fall gracefully array into the neck without any bumpiness or angularity.

The neck, which in recent days has been elevated into a point of considerable importance, must be very long, slender, and tapering, very finely feathered, and gradually merging into the shoulders. Snakiness is a term often applied to the head and neck of a Magpie, and it well defines what is required. Without this fineness and slenderness of neck all the other structural properties of the Magpie are of little value, because they require such a neck to show them off effectively.

The chest should be narrow, but full, the shoulders prominent, yet not heary, the flights narrow and fine, tightly braced, and well carried. The legs long and slender, with well-set thighs, so as to give the bird an erect and stylish appearance. The feet small and well spread.

The markings, which used to carry great weight, have fallen into very secondary value; still, they have to be considered, and must be very sharp and clearly cut. The body, shoulder coverts, and flights should be white, the head, neck, front of the chest, the back, rump and tail being coloured. The name Magpie is derived from the wild Magpie, orving to the markings. 
The colours are black, yellow, red, blue, silver, cream, and dun, and in importance follow, in great measure, the order in which I have given them. The blacks are far in front of the other colours.

Reds and yellows are much on a level, as are the silvers and blues. Duns are not so popular as they used to be, neither are they so perfect in points as they one time were. A decided effort is now being made by several prominent breeders to bring them to the front again, and in a short time there will doubtless be great improvement in their head properties. Blacks, reds, yellows, and blues are generally good in colour; the silvers fail mostly in colour of hackle. Creams are very uneven, some looking like bad washy yellows, and others showing a mealiness which is not at all desirable or attractive. Duns also are very varied in shade, some being a hard dark colour, and others a dirty drab; and some are chequery, a great fault indeed. Richness, clearness, brightness, and evenness of colour in all varieties is much to be desired, and when this is obtained with a brilliant iridescent sheen the effect is most striking, the white body setting off the coloured markings in a most effective manner.

\section{THE NUN.}

This is another Pigeon which derives its name from its markings, the Nun's hood or veil which graces its head and throat. This is one of the breeds which seems to have lost some of its former popularity, possibly due in some measure to the great difficulty of producing high-class specimens. It is rather peculiar, but lovers of the Nun are most steadfast in their loyalty, and there are to-day a number of breeders who have been steadfast in their adherence to it for many, many years, notwithstanding its decline in popular favour. The reason it has not advanced is because it has not drawn unto itself fresh followers in sufficient numbers to make up the natural leakage which takes place in all varieties. This, however, is now being remedied, the club deroted to this variety having created many new fanciers. 
Colour and markings are the chief attractions of the Nun, although some say its leading characteristic and property is the crest. Close observation for many years convinces me that markings invariably clominate all other properties; the shell or crest certainly is important, but it is not the first property.

In size and shape the Nun resembles the ordinary Long-faced Tumbler, and should be a compact, cobby bird, of alert, graceful carriage. The head, generally called the cap, and bib should be coloured, the latter cxtending with a nice clean sweep well down the neck towards the breast; the wider and deeper the bib, the more valuable the bird possessing it.

The shell or crest, which in my opinion is the second point, should rise perpendicularly at its juncture with the base of the head, and be carried very erect, although slightly curving inwards as it rises from the ears, that is the bend, although very slight and at the tips of the feathers, should be towards the front, twisted or turned feathers spoiling the beauty of the shell completely.

The flights should be short, and in colour should follow that of the bird, black, dun, blue, red or rellow; Io by Io is the standard of excellence, but few attain it; still there are many 9 by 9 , and this is considered good. The tail should be short and coloured, like the head and bib, and the colour should be solid and bright. The rest of the body, including the shell, is white.

The eve and cere are points which should receive more attention than they do. I much dislike a fiery eye and a coarse cere; they both detract largely from the other properties. The eye should be milk or silvery white, and the cere very fine, dark in colour, and close fitting.

The colours are blacks, duns, reds, and yellows, but blacks are the most numerous, even as they are the most perfect, the other colours all failing considerably in shell.

TIEE ARCHANGEL.

This is essentially a bird of colour and lustre, and it is totally different from any other variety known 
to the English Fancy. From whence the name was derived there is considerable difference of opinion, but most probably it arose from the richness and brilliancy of its plumage, as there is no reason at all for connecting the bird with the country known by the same name.

In shape and size the Archangel resembles the urdinary common Tumbler. The head should be rather long, free from stoppiness or angles, and from its base should rise a full, strong, yet maneless, high, needle-pointed peak. Many grand coloured birds, however, come shell-crested, but not so frequently as they used to do. The beak should be long, slender, and straight, and of a horny colour. The beak wattle very fine and close fitiing. The eye, bright rich orange in colour, should be surrounded by a fine, small, close-fitting cere, which if rich in colour enhances the other properties.

Colour is the great consideration; in fact, it mioht be said to be the Alpha and the Omega of the Archangel. The head, neck, chest, belly, and thighs should be a rich deep bronze; smokiness or mealiness are great faults, solidity and brightness being at1essential. The shoulders, back, and rump should be rich ebony black. The tail also should be black, although few birds to-day are black in tail, most of them showing a bluish or slaty tinge, even the best showing a bar if nothing else. The flights when closed appear black, but when opened the webbing should show a decided bronze tinge running throughout. We have here two decided ground colours; strange to say, each has its own peculiar lustre. The lustre which should adorn and cover the bronze portions of the body should be of a red or pinkish hue, clear, bright, and scintillating. The shoulders, back, rump, and the tail too, if possible, should show it rich green metallic lustre; the back and rump of a good Archangel possess a wonderful display of sheen. Common faults are a darkness of head, pale colourless ceres, smokiness of thighs, paleness of rump, bluishness of tail, and an orer-running of the pink lustre on to the shoulders. 


\section{THE JACOBIN.}

This breed was at one time included amongst the German Toys, but to such a high pitch of excellence has it been bred by its many and devoted admirers that it has for a long time now been considered one of our high-class Pigeons.

The Jacobin is a medium-sized Pigeon, looking larger than it really is by reason of its peculiar hood and chain feathering, and its length of flights and tail. The neck is long and well arched, the chest full and prominent, the shoulders wide, the body rather elongated, the legs short. It is difficult to obtain a great length of feather on a small bird, therefore, when a small bird is profusely feathered it is most highly ralued. Carriage, in these latter days, has come to be considered a property of value, and the old-style short, squatty Jacobins are completely out of clate and out of farour. An erect bearing of the head and neck is essential if the feather beauties of the bird are to be seen to the best adrantage.

The head should be round, broad, and rise somewhat abruptly, yet display no stoppiness. The beak short, moderately thick, and of a downward tendency. The beak wattle should be small and fine. The eve white or pearl; a gravel or red eve is a bad blemish. The eve wattle is small and circular, yet somewhat prominent, due to the fact that it does not get the hardening influence of the atmosphere upon it.

The Jacobin is essentially a bird of feather, and for this reason is it that in certain parts of the kingdom, where the atmosphere is mild and humid, do we find a pre-eminence of breeders of the Jacobin. Taking the hood first, which, as its name indicates, is the covering of the head, it should rise from the back of the skull in reverse order, and cover the head as far as possible in a regular and unbroken outline. The hood must not be erect, or stiff, but fall gracefully over the skull. The chain should form ars unbroken continuation of the reversed feathers in reguliar sequence on $r$ ach side of the neck. from the hood to the rose, extending as far as possible and meeting in the front. 
The rose is a round spot just above the shoulders, from which radiate the hood, chain, and mane; the latter property consists of long, strory feathers, which support the hood; the mane should grow well out from the juncture of the neck and the shoulders, and proceed upwards regularly and evenly till it meets the hood. A strong, firm, well-filled mane adds greatly to the finished appearance of a good Jacobin: in fact, without a strong mane it is impossible to have that squareness at the base of the hood which is so much desired.

The markings of the Jacotin are as follows: The skull should be white, from the beak to the bast of the hood; the rump, tail, and tail coverts should he white, also the ten outer flights; the rest of the bird should be dark, that is in the coloured varieties, the one exception being the white, which, of course, is white all over.

The colours are blacks, reds, vellows, whites, kites, strawberries, duns, mealies, silvers, blues, and chequers. The blacks, reds, yellows, and whites are styled standard colours and the others off-colours, an they are more or less offshoots.

The faults most usually found are slackness and shortness of feather, foulness of face, odd and short flights, long heads, odd and wrong coloured eyes.

THE FAN'TAIL.

This is one of our most charming of Pigeons, and those who want to know more about it than can be crowded into a general manual like this must turn to my monograph, "The Fantail Pigeon." Outside of the Fancy proper no Pigeon is more popular than the Fantail, whilst its popularity as an exhibition bird is shown by the fact that year after year all over the country classes for Fantails are increasing in number, and meeting with good support. My friend. Mr. Richard Woods, although essentially a hard feathered devotee, is so fond of the Fantail that he has described it as "the ladies' bird." What higher testimony to its grace and charm could be rendered? The chief charm of the Fantail is that it 
is dainty in every way-dainty in size, dainty in shape, and dainty in style. There is nothing coarse or commonplace about the Fantail, and this it is, no doubt, which accounts for its great and increasing popularity.

The chief points of the white Fantail are:-

The head should be small, fine and snaky, free from peak or shell. The beak should be thin, flesh colour, and of medium length, the upper mandible slightly curred at the tip. The beak wattle small, and fine in texture. The eve dark hazel or bull, with very fine flesh coloured cere.

The neck should be thin, nicely curved and tapering well off as it approaches the head, in length corresponding with length of back, so as to enable the head to rest closely at the base of the cushion.

The body points are shape: Small and round. Back: Slighty hollowed in centre. Length of back: In proportion to length of neck, enabling the head to rest on the cushion with ease. Rump: Of sufficient size and strength to balance the tail erenly. Chest: Round, like a ball.

The cushion must be full and massive, the feathers at the front and back overlapping each other, and extcnding well up the tail feathers.

The tail slightly concave, and circular, closely filled with long, broad, evenly set feathers, well orerlapping each other.

The legs must be moderately short, not stilty, and free from feathers below the hocks. The feet small, fine, and neat. The colour of legs and feet bright red.

The carriage is most important. The bird should stand on tip-toes, and walk in a jaunty manner, with its head thrown back in a graceful manner, resting closely on the cushion; the chest upright, in a straight line with the legs; the wings being set on fairly low and clonely braced, with the flights just clearing the lowest tail feathers and almost meeting at the tips. The tail must be carried well up, not being allowed to drop or incline forward, and the legs well apart, the hocks being forced forward by the action of the body. 


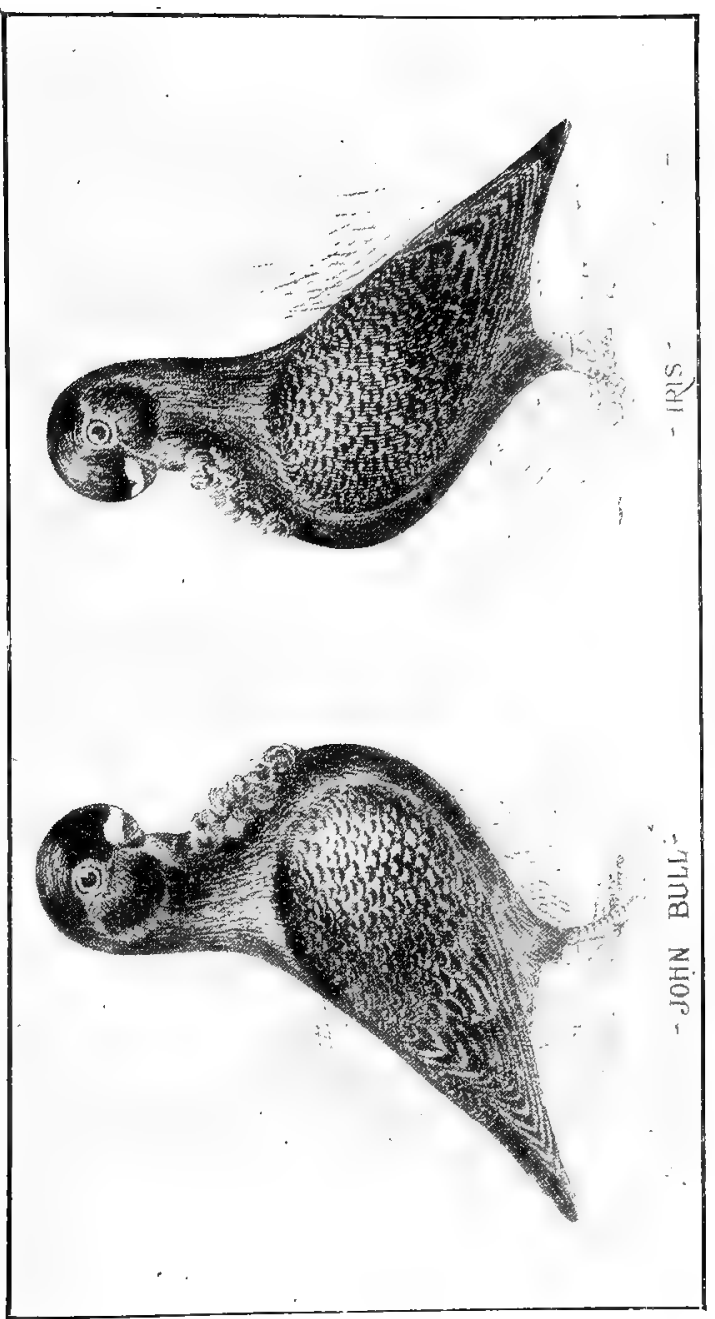

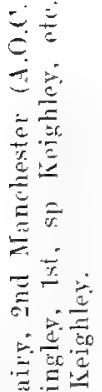

mi

है

है

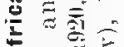

प

ᄃ

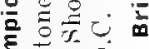

है

สำ

o

in

年- -

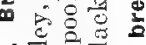

< $\overline{0}$

×

这光。

可焉

을

$3+\underbrace{}_{0}$

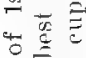

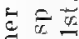

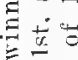

욜

을

是是

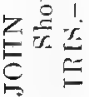



Motion.-This is a convulsive jerking or twitching of the neck, and apparent uphearing of the chest, the head seeming to bounce gently up and down on the cushion, with constant tremulous quivering of the body. fitting.

The plumage must be pure white, hard, and tight

Other colours are blues, blacks, reds, vellows, silvers, duns, chequers, and the fascinating Saddles, which are seen in all the above colours. In blues, blacks, silvers, duns, and chequers, the beaks and eye ceres should be dark, and the eves white or pearl. In reds and yellows the eve is orange; the beak horn or flesh colour. The Saddles follow the whites in eve, cere, and beak. Whites are the most extensively kept, the blacks and blues coming next. Saddles are pretty widely distributed, but good ones emanate from few studs only. Reds, yellows, silvers, duns, and chequers are not numerous, and only a few excel in all-round Fantail properties. The peculiar laced Fantails had a few years ago almost died out, but now they show signs of coming again.

A word of warning to those who propose to keep, Fantails. Roomy lofts are required, and covered flights, as the birds are soon ruined if the weather gets at their plumage. Further, during the show season 110 perches should be allowed in the house.

\section{THE TRUMPE'TER.}

The Trumpeter derives its name from the peculiar trumpeting character of its voice. It is a native of Central Asia, and, I regret to say, is not very extensively bred by English fanciers; in fact, it is not so popular as it used to be. The Trumpeter is a large bird and hardy. It is a difficult bird to keep in good show condition, and this probably accounts for its failure to make headway with English exhibitors. It is most exasperating to send a bird array to a show in good form, and to have it returned with much of its foot feather broken, and what is not broken so messed and be-draggled that the bird cannot be shown again for some time. 
The feather properties of the Trumpeter are its chiel points, and these are of a varied character. First comes the rose, which must be very close and conipactly feathered, and should radiate from the centre of the skull, falling away gracefully over the beak and sides of the head; the more circular and compact, the more valuable the rose. The crest, or shell, should be very large, extending from eye to cye, round the back of the head, from which it should rise and incline slightly towards the front. It must be fine, compact, unbroken, and erect; the feathers must not be turned or tristed, and there must be no gaps. The leg and foot feathering should be as profuse as possible from the hock downwards to the extreme point of the toes, and be evenly arranged.

The body should be large, the neck short and thick, the chest bold, broad and prominent, the shoulders well developed, the flights long, and broad in weh. The legs of medium length; the carriage of the body should be crouching or squatty, and the head carried low, so as to show the rose and shell. The tail is long, as is the body feather; in fact, the main characteristic of the Trumpeter is its great length of feather, thus there is nothing neat or smart about it.

Blacks, mottles, whites and splashes are the colours most commonly seen. There are also some remarkably fine reds and vellows. As ret, they are in few hands, but when better known should become exceedingly popular.

During the breedino season the rose, the foot feather, and the long feathers round the vent should be clipped. If this is not done the eggs will be broken, and few of them will be fertile.

\section{THE SWILLOW.}

This is one of the most largely kept German Tors in England, and it is also one of the most beautiful ind pleasing. It is very handsome, and when in good feather presents a very picturesque appearance. "The colours are blacks, blues (both barred and barless), silvers (also barred and barless), reds, yellows, and rhequers. 
In size the Swallow is medium; in shape the head is somewhat flat and rises abruptly from the beak; the body is round and plump, with a short slender neck; the neck and back are broad, with prominent shoulders, the legs somewhat short, giving the bird a squatty appearance. It is shell crested, and hearily feathered on the legs.

The markings are "t dark cap, which should run horizontally in a line with the centre of the eve, and extend from the beak back to the shell; the upper mandible is also dark; the whole of the wings and shoulders should be coloured, also the hocks and foot feathering; the rest of the bird should be white. The foot feathering is not very long, but the longer and more perfect it is, the more valuable is the bird from an exhibition standpoint.

\section{THE, FAIRY SWALLOW.}

These are generally styled by English fanciers Spot Fairies, and it is a much controverted point as to whether they are Swallows or not. Some writers class them as such, whilst others object to such classification.

In shape, carriage, and feather they resemble the Swallows; they are, however, more profusely feathered, and the markings are different. Instead of the dark cap of the Swallow the Fairy has only an oral spot on the forehead. The shoulders and wings should be dark, and the whole of the long foot feathering. The wing bars and all the rest of the plumage is white. The most common colours are blacks and blues, although reds, yellows, and chequers are sometimes seen. Some are laced upon the shoulders, and the flights tipped with an oral white spot. The eyes are dark, as is the upper mandible in blacks; in the other colours it is of a light horny tint.

The chief points are richness of colour, clearness of marking, shape and carriage of shell, and length of foot feathering. 
THE FRILLBACK.

This bird is of the common dorehouse Pigeon shape and size, rather short on the legs, and long in flights. It is grouse-legged. The eyes are red. The peculiarity of the breed is that the feathers of the wing corering and back are frilled, and grow in reverse fashion to those of other breeds. Frillbacks may be found in all colours, but those most frequently seen are whites, grizzles, and mealies.

\section{THE SPOT.}

This is a white Pigeon of the common type, with a dark tail, and a spot of the same colour. The eyes are "bull" or dark coloured. The face marking or spot is about the size of a good large pea. They are clean-legged and grouse-legged. The beak is bicoloured, the upper mandible being dark, and the lower white.

\section{THE BLAZEF $A C E$.}

The Blazeface is found in a variety of colours, and is mostly valued for its richness, depth, and clearness of colouring. The blaze mark from which the name is derived is a white, clearly-defined oblong streak of white just over the wattle, in the centre of the forehead. This mark must not be large, or the bird loses in value; it should not exceed an eighth of an inch in width, and about a quarter of an inch in length; the whole of the body is coloured, but the tail and its coverts are white. The bronze-winged variety is known in England as the Fire Pigeon.

THE STARLING.

This is a black Pigeon, with a well-defined crescent-shaped marking on its chest of a greyish colour, ticked or flaked with reddish black streaks. It has also white wing bars. The plumage should be tight and compact, and the colour rich and showing plenty of sheen. The eyes are red. In shape it is of the common Dorcinuse style, and of small size. 


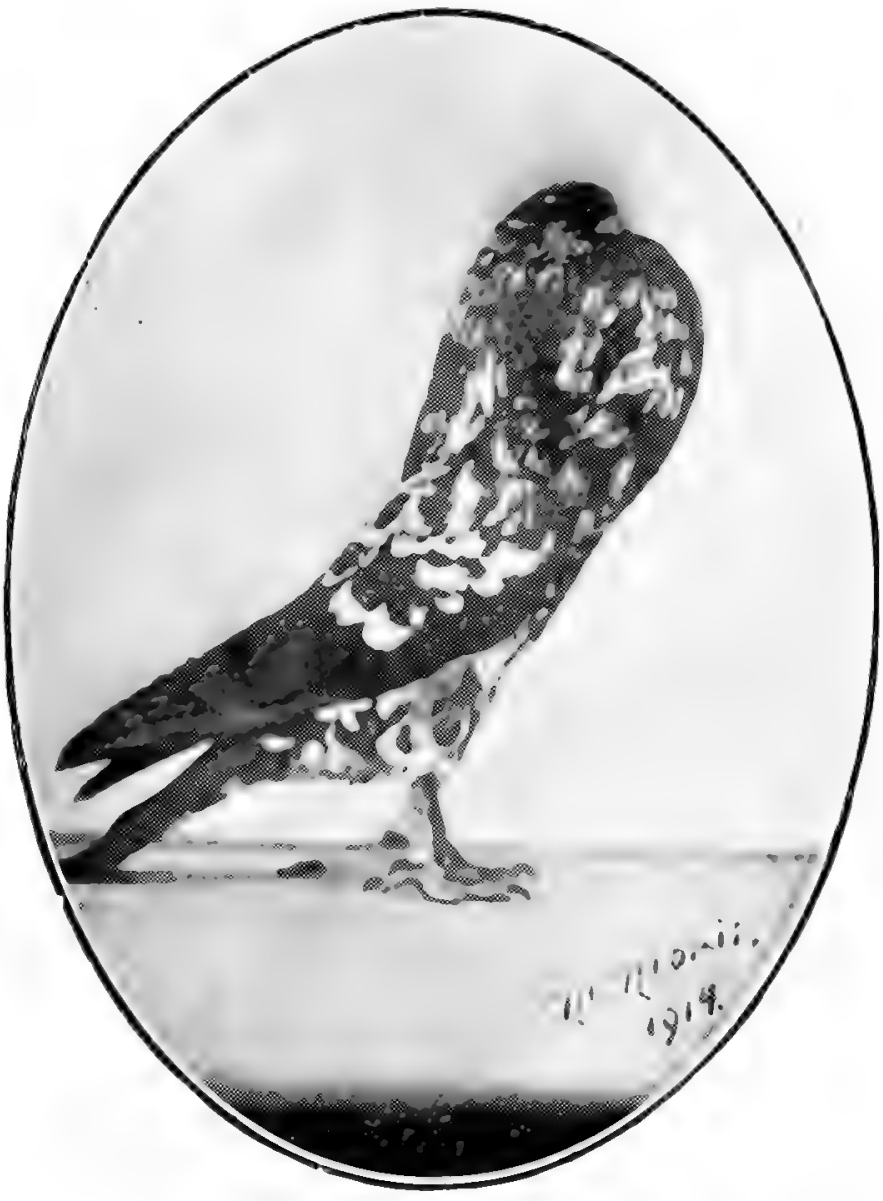

Lille Cropper Cach.

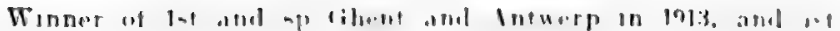
and sp Liege, Brussels, and Lille in 1914.

The lille is an old variety of French Cropper. It is now almost extinct, and is known to but few British fanciers. 

THE SWIFT.

This is of eastern origin, and doubtless derives its name from its resemblance to the Martins and Swallows in its great length of flights and tail, its shortness of legs and claws, and its carriage. The Swift is not by any means a large bodied bird, but its length of feather is extraordinary and unique, being altogether out of proportion to its body, and much longer than that of many much larger Pigeons. The wings, when out-stretched, will in a good specimen measure as much as a yard from tip to tip. It naturally follows that such extreme length of feather cannot be gracefully carried, therefore in the show pen the Swift is not by any means an attractive Pigeon; and it is not much better when on the wing, being a slow and somewhat ungainly flier. The head is round and full, but not large; the eye is red, the beak short and stout, the neck short and thick, the shoulders broad and prominent. It possesses great depth of keel, with a long, straight breast-bone.

The colour is a peculiar ashy, silvery dun shade, with a powdered appearance about the neck.

\section{THE DEWLAP.}

This bird is usually represented at our large shows, but it is not a handsome Pigeon by any means. Its dewlap or gullet is enormous. It is a big Pigeon, with a large white spot on the forehead, a white spot on each side of the neck, and white outer flights, and barred on wings and tail. In shape it is large, stout, and cobby, something like the English Owl, but larger. It has gravel eves; its beak, which is short and thick, has a white upper mandible and a dark lower one. The colours are blues and silvers.

\section{THE ANCIENT.}

This German bird is seldom seen at our English shows; in fact, speaking generally, the German Toys are not seen so often as they used to be. The Ancient is a smart little Pigeon, being midway between the African Owl and the English Turbit. It is a plump, cobby bird, with erect carriage, and the motion of the 
Fantail. Its head is round, the beak short and thick, and nicely curved at the tip. The ere is white, the cere red, ind it is grouse-legged, the body feathering being hard and tight, with close carriage of wings. Its matkings resemble those of the Magpie, with the iddition of an oval-shaped bib or belt of white, called the crescent, but which is not crescent shaped, although it rums acrosn the chest like unto the crescent of the Starling and the Pouter. In clearness and brightnen of colour, and richness of lustre, it is most charming. In a word, it is one of the most beatliful I'igeons known.

\section{'LHE STLIIIII.}

This bird is a Cictman, from Suabia, hence its name. It is one of the most beatutilul of Pigeons, its feathering showing the most charming lacing and chequering. The ground colour is of a dark slate, almost black hue; eath of the feathers on the head and neck should be tipped with at creamy, silvery white, which, with the ordinary green and purple lustre of the neck, makes one of the prettiest combinations one could wish to see. The back and scapular feathers, and wing coverts, should be spangled with black on their creatmy extremities. Sometimes this spangling is triangular, at others it takes the form of even lacing. The outer Hights should be black, with creamy white spots near the ends. The tail is sometimes barred, but the perfection of marking is the spot on each feather lilie unto the outer flights. In sliane and sise the Suabian is like unto the Starling, whom it much resembles, and from whence some aluhorities claim it has been bred.

\section{'LHÊ IITICINTH}

Is said to be of Firench origin, and is very similar to the suabian in colour and shape, although sonewhat larger. It liffers, lowerer, from the Sualian in its markings. The shoulders are marked or chequered with white and blue. The Porcelain very closely resembles the Hyacinth, and hats doubtless come from the same original stock. 


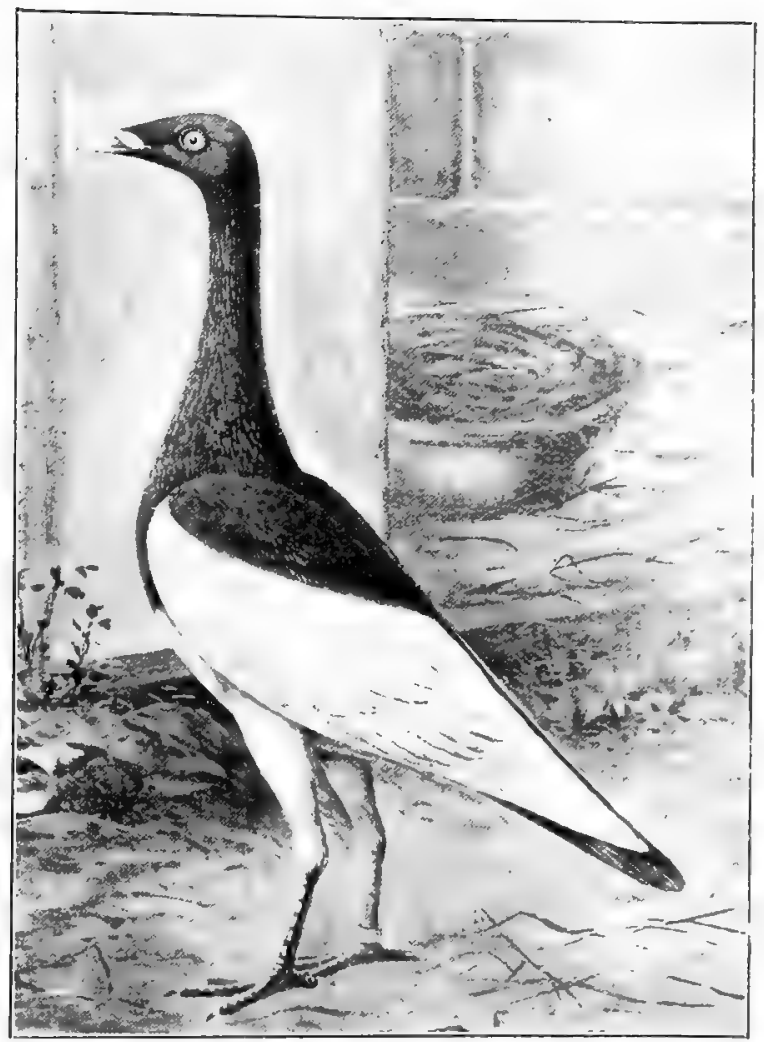

"Cambridge Yellow Queen."

An unbeaten Yellow Magpie Hen.

Bred by Messrs. Heaton and Driver, of Cambridge. 

I'HE ICE.

'Ihis is a bird of which I am very fond, and have often wondered why more of our English fanciers have not taken it up in earnest. It is a small Pigeon, about the size of a Tumbler, is of beautiful, delicate lavender blue ground colour. Some are wholecoloured, excepting the bars; others are laced, others chequered. The wings are darker in colour, and have most lovely bars of a snow-white colour, neatly edged with black or dark blue. The eyes are a rich, fiery red, with most beautifully fine ceres; the beak is fine and dark in colour. Most of the birds seen in England are grouse-legged. Its peculiar natme comes from the wonderful and unique frostlike bloom which pervades its plumage, particularly on the neck and shoulders. In my visits to Continental shows I have often seen very pale silver Ices, self coloured except that they have a very fine, narrow, dark coloured bar. They are a very beautiful variety.

\section{THE SHIELD.}

The Shield is a Pigeon marked on the shoulders like the Turbit, but with white bars, the rest of the bodv being white. It is met with in a variety of colours, all of which are very rich and clear. The Shield is plain-headed and shell-crested, and grouselegged, the foot feathering being a great feature; the longer it is the more valuable the bird. Blacks and reds are the most common.

\section{THE PRYEST.}

This is one of those peculiar instances of nomenclature which it seems impossible to fathom, the hood or cowl, which may be likened unto the Shell-crest, being the only point that could possibly lead one to see any connection between the Priest and its human namesake. In colour it is whole or self, with the exception of the head, which is white, and the wing bars, which are also white. The forehead is ornamental, with a tuft of feathers growing the reverse way. The legs are grouse-feathered. The upper 


\section{PighoNs AND Ali ABot'T Them.}

mandible of the beak is white, the lower one being dark. The colours are reds, blacks, yellows, silvers, and chequers.

\section{THE MODENA.}

This, one of the most charming and beautiful breeds ever introduced to England has made rapid stricles in poptularity during the twentieth century. Nany years ago it secured a number of adherents, and classes were provided for it, but its popularity waned until about the year 1910 when a decided impetus was given to it by the advent at the Crystal Palace Show of a number of birds from Belgium. Since then the Mixdena has made one huge triumphant progress, and hefore its charms liave fallen men who have been lifelong adlierents of such diverse breels as Carriers, Dragoms, Owls, Magpies, and Orientals. To-daythere are few shows without classes for the Iodena, and at our large shows ther secure a very extended classification. It is a smart neat bodied Pigeon, mnucthing like the Leghorn Runt in shape and carriage, but is not so large or stout in body neither dous it possess the tremulous action of the Leghorm Runt nor its extremcly high cocked tail. To attempt to speak of the colours of the Mockena in a small handbook of this character would be to attempt the iminsibible, so great is the diversity and multiplicity of its colouring and marking, the ground colours which are many being laced, chequered, and variegated in the most wonderful manner.

It has been said that there are orer one hundred and fifty divisions of colour, evenly divided between the Selfs-Schietti-and the pieds-Gazzi or Nagpies. In addition to the Schietti and Gazzi there is the Magnani, which is a mixture of colours somewhat like a Roman iravement, or a patchwork quilt, or which may he described as marbled. Wonderfully weird and fascinating are the endless markings and colourings of the Modena. On the Continent the birds are invariably classed in the Hen Pigeon Section with the Maltese, Lcghorn Runts, Florentines, etc, and there much is made of the peculiar carriage 


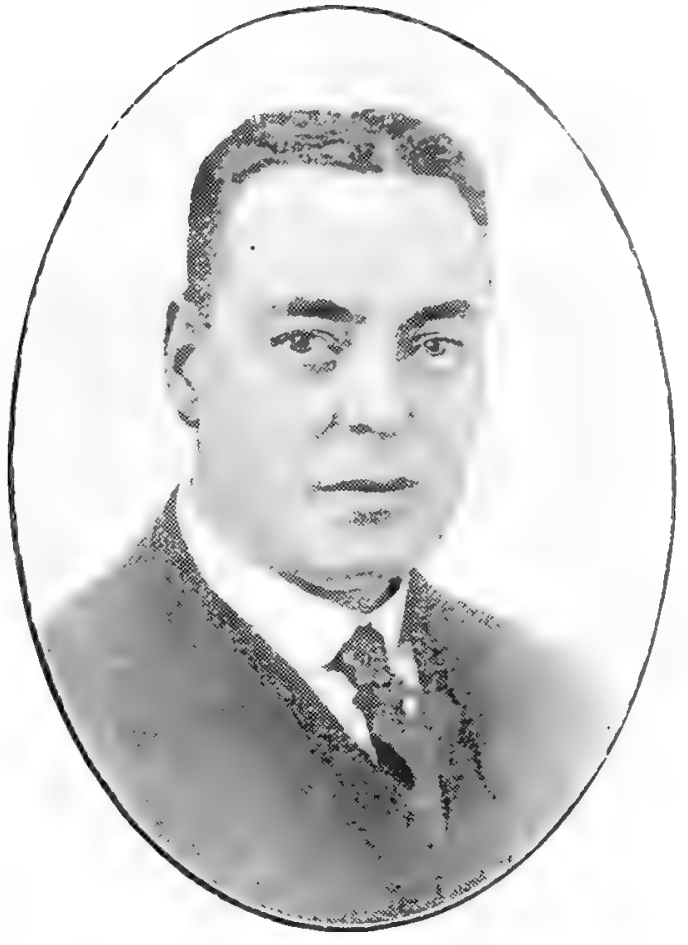

Mr. Leonard Gorman,

Breeder and exhibitor of Long, and Short-faced Tumblers. Winner at all our leading shows. 

of tail which distinguishes the Hen Pigeons. Mr. J. C. Lyell in "Fancy Pigeons," and the late Rev. W. F. L umley in "Fulton's Book of Pigeons" speak of the tails as being carried horizontally, and the illustrations in both works so portray them. This is altogether misleading, and is not in accordance with Continental or English ideas, and why two leading English writers on Pigeons should so erroneously describe what is one of the outstanding features of the breed I cannot understand.

The Modena is a bird of curves. Curved and full is its head, curved its neck, curved and full its chest, curved its back and vent. How can such a structure carry a straight tail? The body from behind the legs takes an upward curve, and as the tail grows out from the rump which is upward curved how can it possibly be horizontal? The flights in a first-class specimen rest lightly on the cushion and tail, and the carriage of the bird is something like that of a good Fantail, the bird sceming to tread on its toes. Grcat and many are the fascinations of the Modena.

\section{THE IEGHORN RUNT.}

This Pigeon is also known as the Florentine. It is a smart, stylish Pigeon, not at all ungainly, like the common Runt. It has great length of neck and leg, the neck being carried swan-like, and showing much tremulous motion at times; the tail is carried very high, whilst the body is short, as are the flights and tail. The body feather is hatd and tight. It is found in all colours, the barred varieties being the most common. With its long, clean legs, long neck, and short, cocked tail it presents a most comical appearance, and it is strange that its very oddity has not made it popular, because it is very hardy and active.

\section{THE CAPUCHIN.}

The Capuchin is seldom seen in England. It is a charming little Pigeon, whole-coloured excepting the tail, which is white, Blacks being the most common. It is small in body, very erect in carriage, and is shell 


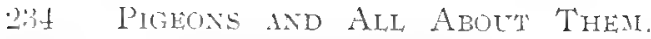

crested. The wattle, like the tail, is very white, as is the ere, which has a fine lark cere. In addition to the whole-coloured birds, Barred stues and Silvers are also secu. The lorely dark cere now seen in Black Self Tumblers was introduced by crossing with the Calluchin.

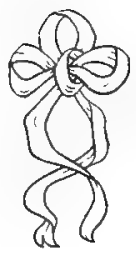




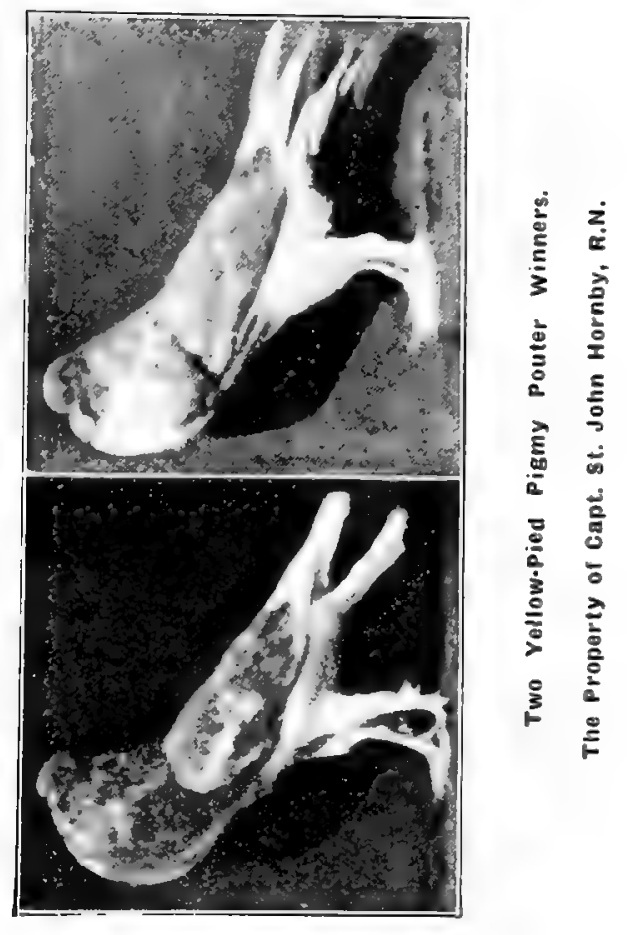





\section{CHAPTER XI.}

\section{DISEASES.}

Pigeons are very healthy birds, and if kept under sanitary and natural conditions give their owners little trouble in the way of doctoring. In a work of this kind there is not room for a long dissertation on the cliseases to which Pigeon flesh is heir, apart from the fact that there exists a very complete treatise dealing with such. I shall, therefore, only touch upon a few minor or common ailments in this chapter, and refer my readers to that admirable work by Mr. Richard Woods, "Diseases of Pigeons and their Treatment," which is the standard and most reliable book on the subject.

In connection with disease, as with many other things, "prevention is better than cure," and if fanciers would only attend to the small details of ordinary management, especially the items of grit, water, fresh air, and cleanliness, there would arise little occasion for the medicine chest to be resorted to. Still, however careful one may be in their management, there are times when disease makes its appearance from causes quite beyond the control of the owner.

For instance, a bird which has been to a show may come in contact with a diseased bird, be placed in a pen in which such a bird has been, or have to drink out of a tin which has been used by such a bird. Again hereditary taint may cause discase to show itself; particularly is this so in regard to scrofulous diseases, to which, unfortunately, many strains of high-class Pigeons seem pre-disposed.

In dealing with diseases in any form one needs to act promptly, and with decision. "A stitch in time saves nine," therefore I would urge upon every fancier the supreme importance of becoming thoroughly familiarised with every bird in his stock. 


\section{PIGEONS AND AlL ABout Thear.}

A good fancier, that is, one who takes an intelligent interest in the welfare of his stock, can tell at a glance if a bird is well or ill. Such a fancier notices at once any disinclination to feed, or any refusal to bathe-the two surest indications of something being wrong. Then the character of the excreta affords a most reliable tell-tale as to the state of a Pigeon's health. Therefore the young fancier who notices any listlessness, any drowiness, any humping or puffing u1 of the plumage, any refusal of, or inordinate greed for, food, should look around him for the cause, and not stop till he finds it. He should also at once administer some mild remedy, and here let me remark that it is far better for the inexperienced fancier to make use of the remedies which are advertised in " Pigeons " week by week, by such specialists as Dixons, Woods, and others. Therefore, I say that the remedies put up by such authorities must, of necessity, be safer and more reliable for the young fancier than any attempts he may make at home doctoring.

\section{COLD.}

This is the most common complaint and may be caused by a bird having been exposed to extremes of temperature at a show, by the show basket getting wet, or being explosed to draughts or damp, either at home or abroad. The symptoms of ordinary cold are a humped-up appearance of the feathers, a dull look about the eye, with a thin, watery discharge from the eyes or nostrils, sometimes one or the other, sometimes both. If any of these symptoms are noticed in a bird he should be taken in hand at once, removed to a warm corner of the pen-room, given a pinch of Epsom Salts, morning and night, about as much as will lie on a sixpenny bit, and a change of diet, and in a few days all traces of the ailment will have passed.

\section{ROTTP.}

This most dreaded discase is the result of a cold which has not bec1l attended to in the incipient stages. A tird suffering from roup should be isolated at once for its own welfare, as well as that of its fellows, as 


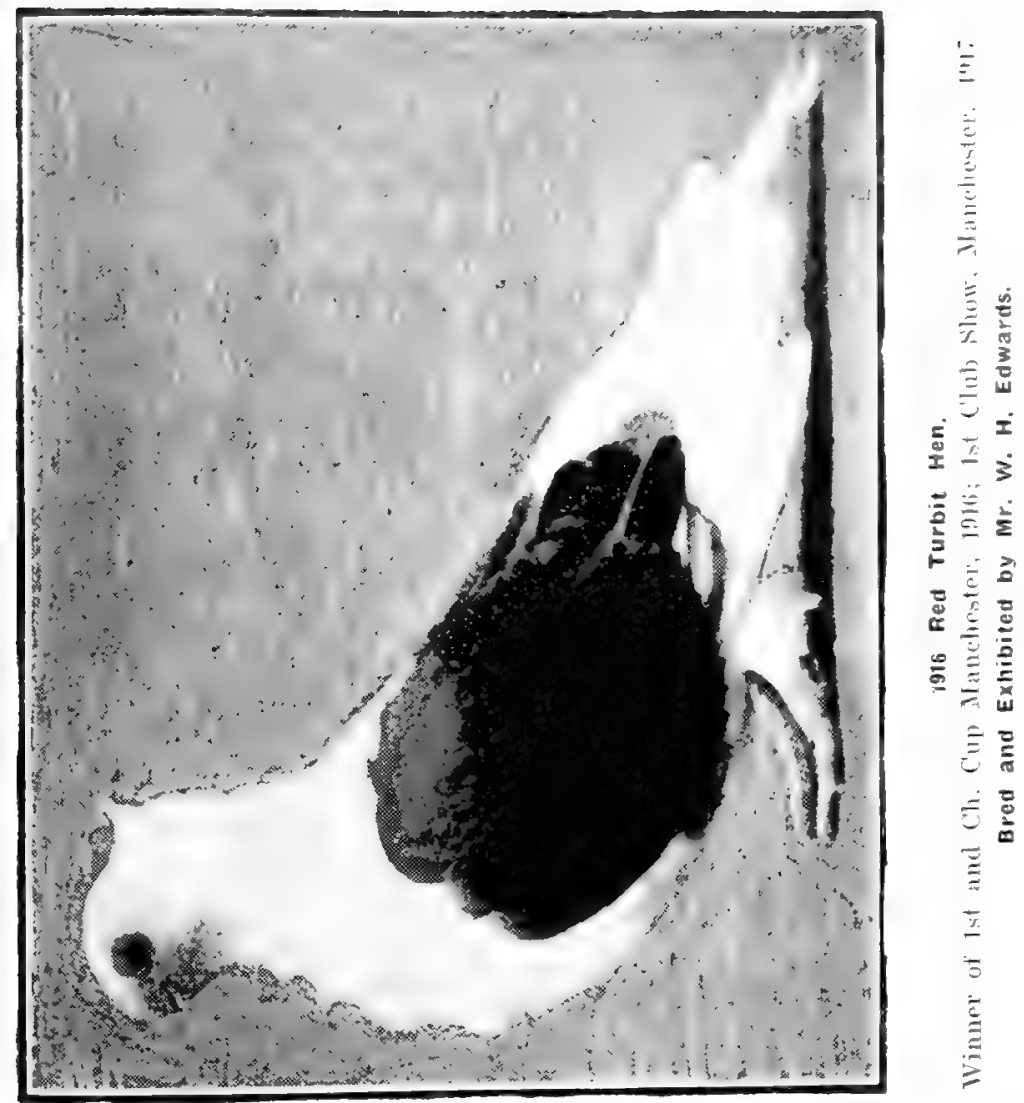



roup is a most contagious discase. The room should be kept at an equable temperature, the bird's eyes and nose well bathod tliree or four times a day with hot water, to which has been added a few drops of Sanitas, or Jeyes' F1uid. Care must be taken to thoroughly dry with a cloth the feathers which become wet during these bathings. The bird should be given some good Roup pill or powdor; all water given it should be warm, and should be given in an carthenware glass or china vessel.

\section{ONEE-EYED COLD.}

'This is a form of cold which, whilst leaving the respiratory organs free, settles in one of the eyes, and often proves extremely difficult to cure. As soon as a bird is noticed with an inflamed and swollen eye, the owner may conclude nine times out of ten that it is suffering from one-eyed cold, especially if there is a watery discharge. In the advanced state this discharge becomes yellow in colour, and loses its watery character. The bird should be isolated, given a pinch of Eipsom Salts morning and night; the eye should be bathed three or four times a day with hot water, for five or ten minutes, dried carefully, and then have two or three drops of the following lotion dropped into the eye from the point of a camel-hair brush. Six grains of sulphate of copper, one drachm of glycerine, four ounces of rosewater. If taken in hand at an early stage a cure may be effected in a few days, but when it is established recovery is prolonged and tedious.

\section{CANIEER.}

Canker is a form of scrofula, and like all scrofulous diseases is very difficult to overcome once firmly established. It arises in many cases from an overheated state of the blood; in some it is hereditary. A blow or wound is often the cause, and a good round up between a comple of birds is frequently followed by canker of the eye, ear, or beak. 'Therefore, whenever birds have been fighting, their wounds should be carefully washed twice a day for a few days with sponge and warm water, a few drops of Sanitas or Jeyes' Fluid 
having previonsly luen surinkled in the water. During the liteuling soasul canker often makes its appearance in the throats of young hirels, and in inexperienced liands such birds pine and die, because the canker luickly grows, hlocks the throat, and the birds are literally starved to death.

The first treatment of canker shotld be internal; the botrels should be cleaused and through them the blond cooled and purified. The following mixture will be found most efficacions: One ounce sulphate of magnesia, one ounce sulphate of soda, one ounce common table salt. Dissolve in a pint of warm water, bottle, and keep corkel. Trse in the proportion of me teaspoonful to a wincglassful of water, or if it is preferterl to give it dry, then take as much as will lic on a sixpence, and give to the bird morning and night.

For canker of the cyc, ear, or beak, the above treatment should he followed for a couple or three clays before any attemut is made to remove the canker. In rcmoving the canker a blunt instrument should be usect, such as the thick end of a toothpick, or the encl of a large match. When the deposit has been removed, the wound sluould be carefully sponged with warm watu and some Canker Lotion applied. There are several good ones advertised in "Pigeons" each weok.

Canker in the throat should be removed immediately it is discovered; there is no time to lose in sitch a case, and no time to allow of the blood being got in order. Operate at once, and give the same treatment for a few days as recommended above.

Canker somctimes forms just about the vent of lircls attaching itself to the lower part of the intestines. The formation grows and grows, the bird becomes thin, diarrheea sets in, caused by the irritation produced on the bowels, and the bird dies without the owner ever knowing the why and the wherefore of its ailing.

In a case of this description only a practised hand could hope to operate with success, owing to the risk of complications arising. If it is impossible to obtain 


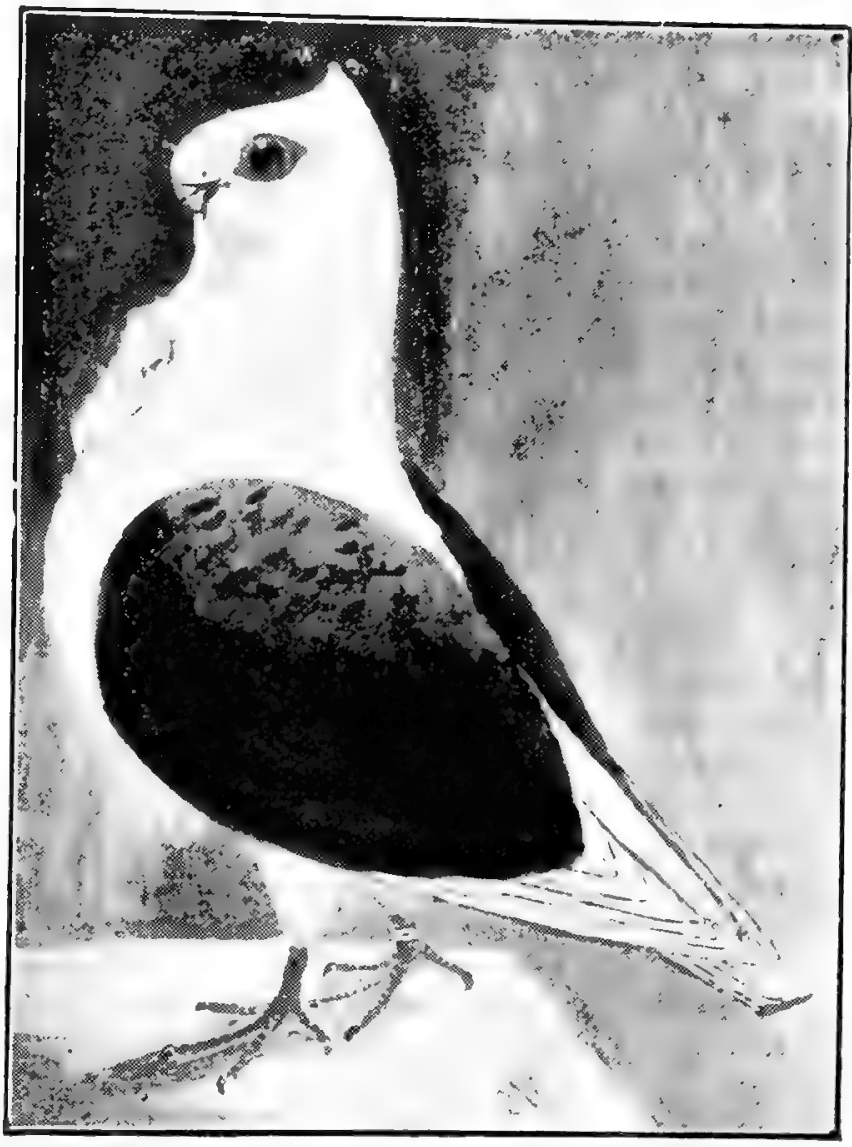

\section{Black Turbit Hen.}

Winner of 1 st and three spls., including spl. for best young Turbit. Altrincham; 1st and Cup Liverpool, and 2nd Dairyonly times shown. 

the aclvice and assistance of an expert the owner inust himself make an attempt. If he fails, the bird can only die, and if he succeeds, his reward will be great. One thing is certain, unless a bircl so afflicted is operated upon death will cuickly ensue, and it will not be a painless death. 'Therefore, in operating, the owner has nothing to lose and everything to gain.

The cancerous mass should be carefully located, and watched for a day or two before the operation takes place. The bird in the meantime should be placed in a pen by itself, fed on wheat and canary seed, and its drinking water medicated as previously described, or else the salts given dry morning and night. In a couple or three days at the most the operation should take place. The cancerous mass should be carefully worked up as close to the outer skin as possible, then a sharp clean cut should be made down through the skin, and the cheesy matter removed with some blunt instrument.

When it has all been removed wash the wound with warm water containing a few drops of Sanitas or Jeyes' Fluid, dry carefully, and anoint with Zinc Ointment. Leave the wound open, on no account close it; if you close it another deposit will quickly form, and the last stage will be worse than the first. Leave it open and wash it twice a day with warm water and Sanitas or Jeyes' Fluid; dry, and anoint with the Zinc Ointment. Should any fresh cheesy matter make its appearance remove it and continue the treatment advised both internal and external. In nine cases out of ten the wound will heal up, and the bird recover.

\section{GOING LIGH'T.}

'This is the fanciers' term for what is really atrophy, or wasting away. Birds afflicted eat most ravenously, yet get thinner and thinner; diarrhoca usually supervenes, and carries them off. Many cases start with simple derangement of the digestive organs, and if attended to in time fatal results seldom accrue. A rose or two of salts, followed by a course of good Tonic Pills, will soon yicld good results. In advanced 
cases commence with a dose of salts morning and night for the first day, then give three drops of landanum in fifteen drops of sweet oil, or five drols of chlorodrne in the same quantity of oil twice a day. I have also found good results from the use of Compound Syrup of the Hypophosphites in the proportion of thirty drops to an ounce of water.

\section{FOUL CROP.}

This is caused by the retention of food in the crop. If birds are left a long time without food they gorge themselves, then drink water, with the result that they are unable to digest the food, it swelling too much to allow of its passing from the crop to the stomach. The crop becomes hard and distended, the bird is unable to feed, and in a day or two is dead unless prompt and effectual measures are taken.

The bird should be caught, then held firmly by an assistant whilst the owner pours a little warm water down its throat; then the crop should be gently kneaded with the fingers, more water poured down, more kneading, and then when the mass is somewhat loosened the bird should be held head downwards, and the contents of the crop gently forced down the throat into the mouth. It is a slow and tedious matter, and all the operations described will have to be performed several times ere the crop is quite empty. When it is empty the bird should be placed in a pen, given some clean water to which a pinch of Epsom Salts has been added, and for food a little wheat and canary seed. This should be continued for two or three days, at the end of which time the bird may be returned to the loft.

\section{A FINAL WORD,}

To be forewarned is to be forearmed. Therefore, I advise all hreeders of Pigeons to kecp a medicine chest. This chest should contain an assortment of the remedies suitable for dealing with all the common ailments to which Pigcons are liable. 
Messrs. Monds and Dixons each sundy medicine chests fitted with the remedies for these common ailments, ancl many a good bird's life may be saver if its owner has a well-stocked medicine cliest at hand.

Remember at all times that prevention is better than cure, and that simple ailments treated immerliately they make their apucarance will save your wets loss.

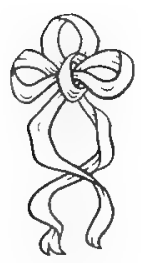




\section{Long-Faced Tumblers}

E. O. JEFFRIES has been breeding Long-Faced Tumblers since $\mathbf{1 8 9 6}$ and during that time has won

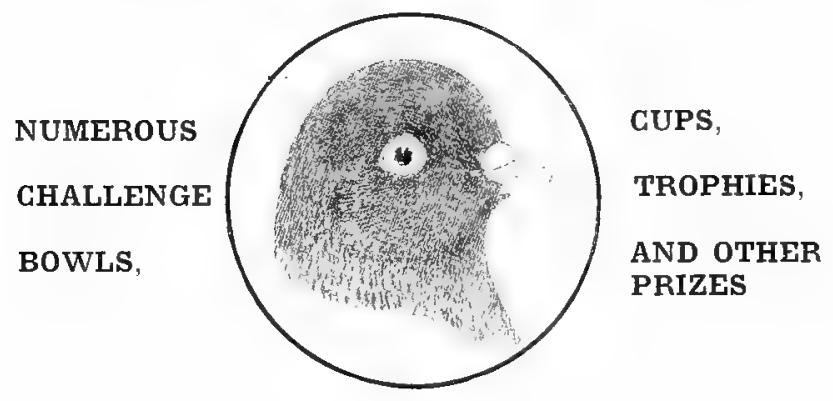

WITH HOME-BRED STOCK AT THE CLASSIC SHOWS.

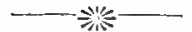

A few well-bred birds in RED AND YELLOW SELFS, MOTTLES AND WHITESIDES usually for Sale at prices consistent with quality.

Correspondence and advice to NOVICES a pleasure.
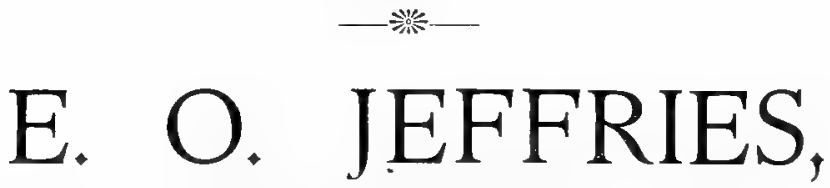

"ELLERSLIE," NORMAN ROAD, CHEAM, SURREY. 


\section{Show and}

Fanciers' Printing

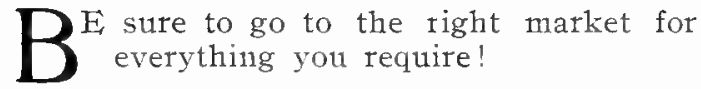

Cheapness and Satisfaction undoubtedly come that way!

It is no use going to your local cycle repairer to build you an Aeroplane!

Go to those who specialise in what you particularly want!

We are specialists in all kinds of Show and Fanciers' Printing. We have facilities for doing this class of work that ordinary printers do not possess. We have hundreds of illustrated blocks to select from. With our long experience of the Fancy we know exactly what is wanted. Please give us a trial. We will satisfy you. We do the printing for some of the largest shows and best fanciers in this country.

SEND. FOR. SPECIMENS.

Printing Manager, Fanciers' Newspaper and General Printing and Publishing Co., Ltd., I D L E, B R A D F O R D. 


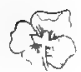

Printed and Published at the Office of

"Pigeons and Pigeon World," Tdle. Bindford.

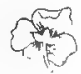









